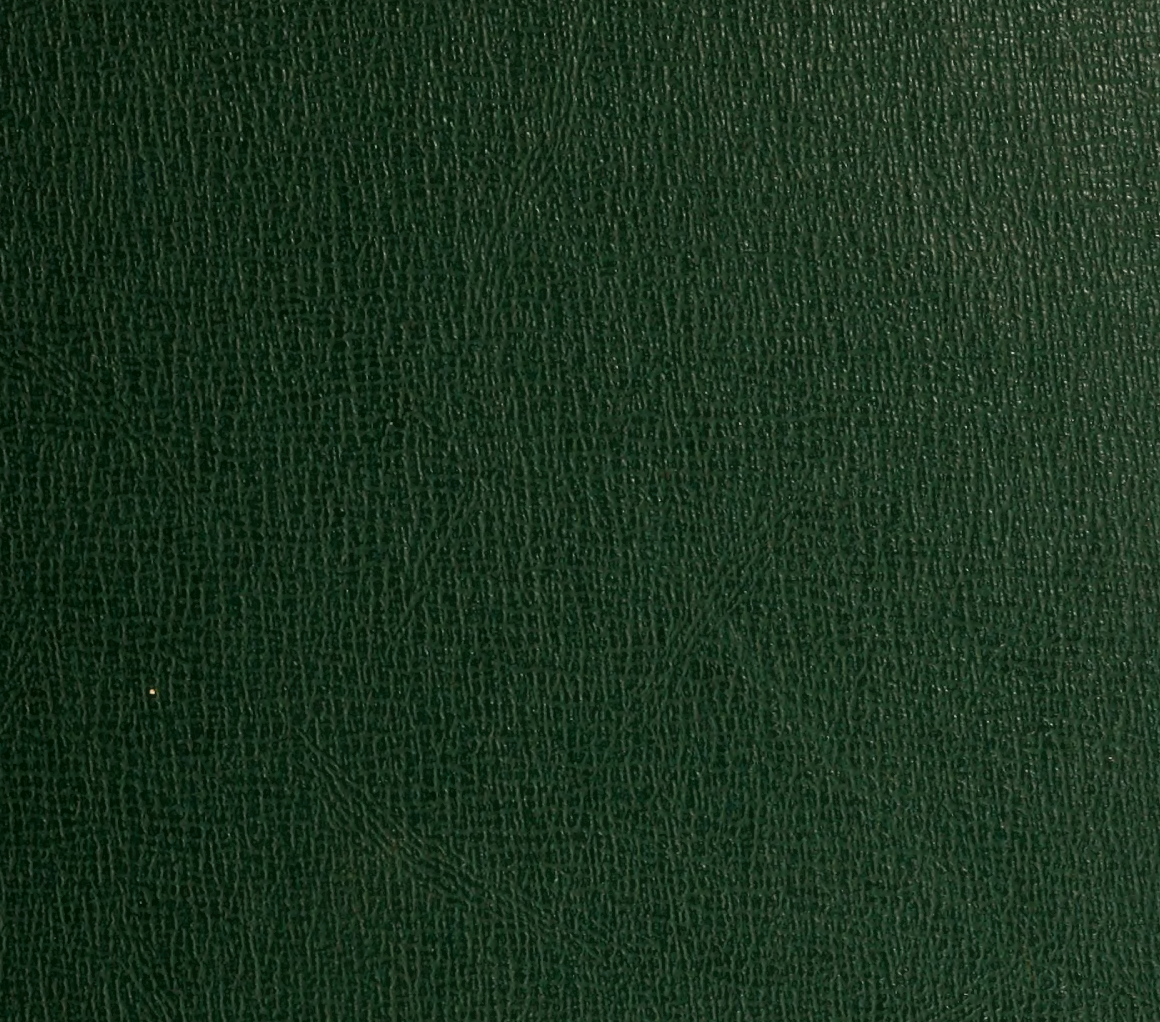

\title{
17 (I)
}
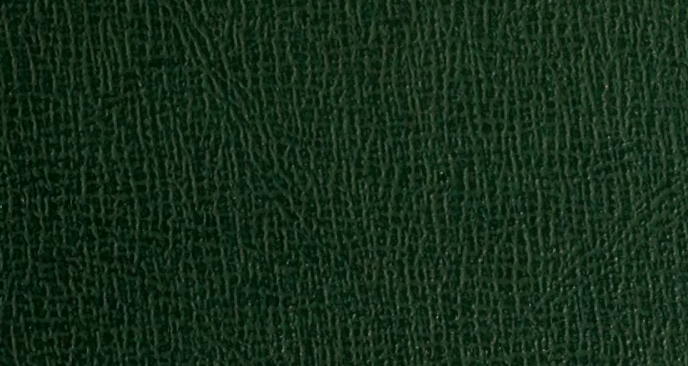

3.5.

Gisto

Yon 


\section{Smithsonian Institution}

Sibraries

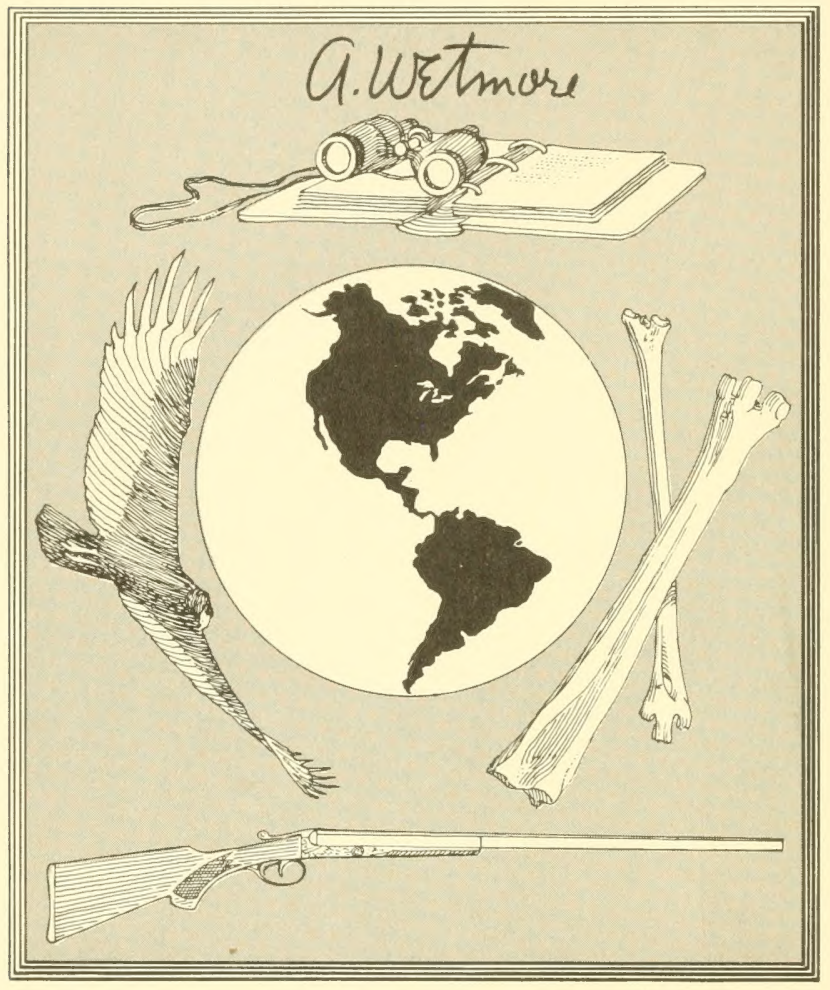

Alexander Wetmore 1946 SixtbSecretary 1953 $\$$ 




A IIST

OF

\section{THE BIRDS OF MARYLAND}

GIVING DATES OF THE

ARRIVAI, DEPARTURE AND NESTING PERIODS OF OUR REGULAR BIRDS;

ALSO

INCLUDING STRAGGLERS AND SUCH OTHERS AS NO DOUBT OCCUR BUT ARE NOT RECORDED.

BY

F. C. KIRKWOOD.

REPRINTED EROM THE TRANSACTIONS OF THE MARYLAND ACADEMY OF SOIENCES.

BA LTIMORE

1895 



\section{A LIST}

OF

\section{THE BIRDS OF MARYLAND}

GIVING DATES OF THE

\section{ARRIVAL, DEPARTURE AND NESTING PERIODS} OF OUR REGULAR BIRDS;

\section{ALsO}

INCLUDING STRAGGLERS AND SUCH OTHERS AS NO DOUBT OCCUR BUT ARE NOT RECORDED.

SMITHSO

BY

F. C. KIRK WOOD.

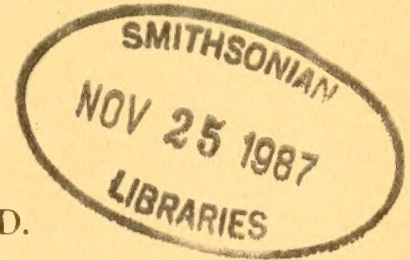

REPRINTED FROM THE TRANSACTIONS OF THE MARYLAND ACADEMY OF SCIENCES.

BALTIMORE

1895 
DEUTSCH

LTTHOGRAPHING \& PRINTING CO.

BALTIMORE. 


\section{A LIST OF THE BIRDS OF MARYLANI.}

BY F. C. KIRKWOOD.

The following list of the Birds of Maryland is the result of a promise made to the late Prof. Geo. L. Smith shortly before his untimely death. It includes all our regular birds and is specially intended to give the time of their arrival and departure and also their nesting periods. It also inchudes such stragglers as I have been able to find record of, and such as no doubt occur, but have not been recorded within our limits, our state being very deficient in ornithological lists.

It is compiled from the author's field work from January 1 , 1SS1, to date, combined with which is that of the following gentlemen who kindly gave me the use of their collections and note books, and to whom I now extend thanks:

Wm. H. Fisher, Baltimore City.

Arthur Resler, " " " "

W. N. Wholey, " " "

A. T. Hoen, " " "

Geo. H. Gray, " " " " "

P. T. Blogg, " " "

J. Hall Pleasants, Jr., Baltimore City.

J. E. Tylor, Easton, Md.

H. W. Stabler, Jr., Sandy Springs, Md.

The late Edgar A. Small, Hagerstown, Md.

Robt. Shriver, Cumberland, Md.

I have also to accord my thanks to others mentioned in the text and to Mrr. Robt. Ridgway, of Washington, and especially to Mr. Chas. W. Richmond, of Washington, who has lindly given his time to an ample review of the manuscript and addud many important notes, giving items from the District of Columbia and surrounding country.

The large majority of my own observations during the last six years have been made in Dulaney's Valley, Baltimore County, and during the last four years I have spent two weelis 
each spring observing our nesting birds. In 1892 and 1893, on the waters between Chestertown and Eastern Bay; in 1894, on Sinepuxent and Chincoteague Bays, between the Delaware and Virginia lines, and in 1895, at Vale Summit on Dan's Nountain, in Allegany County. Flying visits have been made by myself and others to various other points within the state.

I have omitted the word "shot" in a great many cases, but unless it is expressly stated that the bird was only seen, the specimen has been secured; this of course not applying to such birds as are easily identified on the wing.

In compiling the number of a "set" of eggs, the majority of notes are my own; these include all nests with a completed complement of eggs, whether collected or not, and also such nests as held young birds from which none had flown. In some of our commoner species the number is quite large, and shows the variation in a "set" much better than the usual "four or five, sometimes three or six."

I have omitted mention of "second nestings;" a good many of our birds nest twice and some three times; but except in one or two cases I could not identify the same pair of birds, and as nests in all stages, from "started to build" to "birds ready to fly," can be found any day in the height of the season for most of our commoner species, I only give extreme nesting dates, preferring such as record eggs where possible.

A list of the works and publications to which I have made reference is appended. The nomenclature followed, as also the number given, is that of the American Ornithologists Union.

The index kindly prepared by Mr. W. H. Fisher includes all our local names, each bird being referred to under its A. O. U. number.

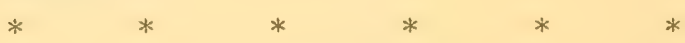

Maryland is situated between the parallels of $37^{\circ} 53^{\prime}$ and $39^{\circ} 44^{\prime}$ northern latitude and the meridians of $75^{\circ} 04^{\prime}$ and $79^{\circ}$ $33^{\prime}$ western longitude. Mason and Dixon's line separates it from 
Pennsylvania and Delaware, and it is separated from Virginia by a line drawn from the Atlantic Ocean to the western bank of the Potomac River and low water line on the Virginia shore, this being the southern border of Maryland from the source down. From the source of the Potomac a line runs north to Mason and Dixon's line. The gross area of the state is 12,210 square miles: 9680 land; 1203, the Maryland part of the Chesapeake ; 93, Assateague Bay ; and 105t, smaller estuaries and rivers.

The three leading topographical regions of the castern portion of the United States, riz, the Coastal Plain, the Piedmont Plateau, and the Apalachian region are all typically represented within the limits of the state. The Coastal Plain, or tide-water Maryland, forms the eastern portion, lying south of a line drawn from W'ilmington to Washington, through Baltimore. This is closely outlined by the track of the Pennsylvania Railroad; it covers about 5000 square miles. The Eastern Shore, except in the extreme north, does not reach at any point 100 feet in elevation, while most of it is below 25 feet. It is deeply cut up by tide-water rivers and bays. This also describes the tract known as the "Neeks" between Baltimore and Harre de Grace. The temperature is much modified by the surrounding water, the southern portion having a mean annual temperature of $55^{\circ}$; but the greater part lies between $56^{\circ}$ and $54^{\circ}$; the northern part averaging 52 ${ }^{\circ}$. Southern Maryland or the Western Shore is different, considerable of it reaches 100 feet, and in places as much as 180 feet. The miean annual temperature seldom exceeds that of Baltimore, which is $55.6^{\circ}$, by more than $2^{\circ}$.

The Piedmont Plateau, or Central Maryland, extends from the Coastal Plain to the Catoctin Mountain, and has an area of about 2500 square miles; it is broken by low, undulating hills, which gradually increase in elevation to the westward. Along the eastern margin, heights exceeding 400 feet are frequently reached, and at Catonsville 525 feet, while at Parr's Ridge, in Carroll County, it rises above 850 feet. At Frederick City, 
the elevation of the valley is about 250 feet above tide. The mean annual temperature ranges from $50^{\circ}$ to $55^{\circ}$.

The Apalachian region, or Western Maryland, consists of a series of parallel mountain ridges with deep valleys between them, eut at nearly right angles by the Potomac River. 'The Catoctin Ridge reaches 1800 feet, and the Blue Ridge, at Quirauk, 2400; while at Middletown and Hagerstown the elevation is 500. The mountains proper begin at North Mountain, and reach in a number of cases 3000 feet and over; while the valleys near the Potomac have an elevation of 500 feet rapidly ascending; the river at Cumberland being about 600 feet. The mean average temperature ranges from $50^{\circ}$ to $53^{\circ}$.

In the above mentioned areas, the Coastal Plain and the Piedmont Platean are ornithologically within what is usually considerel as the Carolina faumal area, as shown by the nesting of the Cardinal, Carolina Wren, Tufted Tit, etc. It will be found to be fairly divided into two sub-fatmal regions. In the lower, or Coastal Plain, will be found the Mockingbird, Fish II awk and Fish Crow, breeding in numbers. In the southern part of Maryland will be found traces of a still more southern faunal area, the Louisiana, distinguished by the presence of the Brown-headed Nuthatch.

The castern part of the Apalachian region is also included in the Carolina faunal area. The Alleghanian fauna covers the mountain region from North Mountain westward, it also appears an the higher parts of the Blue Ridge. This faumal region is the breeding range of the Chestmut-sided Warbler, Rose-breasted Grosbeak, Wilson's Thrush, etc. As this section has never been fully investigated by ornithologists, there remains the possibility, as suggested by Mr. C. W. Richmond, that the Snowbird (Juneo hycmatis) may yet be found breeding in some of the hemlock tracts still standing; this would give a tinge of a more northern faunal area, the Canadian.

A circle drawn round Baltimore City, with its centre at Baltimore and Charles strcets, and a 15-mile radius, will take in over one-half of Baltimore County, and parts of Anne 
Arundel and Howard Counties, a small portion of the Clhesapeake Bay, and Patapsco, Back, Middle and (xunpowder Rivers. In this circle a great diversity of country is found. The part of Aune Arundel included is nearly level and low lying, ats is also the "Necks" of Baltimore County. On there necks and also aloug as far as Havre-de-Grace, are located the famous ducking clubs of the Chesapeake. The water is brackish, or salty, rising and falling with the tide. The timber is principally short leafed pine. The other part of Baltimore and Howard Counties is more or less hilly, rising in places to over 700 feet. The water courses are swift running streams in more or less deep cuts, some even in rocky gorges. There steep banlis and most of the meven land is heavily wooderl with oaks, chestnut, beech, ete. (pines only appearing in small isolated patches), while the level ground is under a high state of cultivation. All observations to which a locality is not given are within this circle; in special cases within this circle, and in all outside it, the exact location is given.

The section usually worked by Messrs. A. T. Hoen, W. N. Wholey, and myself, extends from Waverly, in the northern part of Baltimore City, to Towson, and so through Dulaner's Valley, across the lower half of Long Green Valley to the Harford pike and back to Baltimore; Mr. J. Hall Pluasants working within it around Towson.

Waverly has an elevation of 200 feet and Towson 500. The lowest point in Dulaney's Valley is the level of Loch Raven, 170 feet. The ridge between Dulaney's and Long Green Valleys reaches 560 feet. Long Green V'alley is al! above 250 feet. The Gumpowder River crosses this area in al zigzag course, at nearly right angles, its banks, except in Dulaney's Valley, being precipitous. Four miles of it ronstitutes Loch Raven.

Mr. Wm. H. Fisher's usual basis of observation is from Mount Washington to Lutherville, including Lalic Iioland on Jones Falls (230 feet above tide), and the Creen Spring Talley, which, starting at 260 feet, near Sherwood, gradually ascendis at: 
it goes westward. The country north and south of this valley is very uneven and high (560 feet in some places).

Messrs. G. H. Gray and P. T. Blogg, working to the west of the city, have quite a different country, most of their observations being made in the rocky, heavily timbered gorge of Gwynn's Falls, between Calverton and Powhattan. The bed of the falls at Calverton has an elevation of 80 feet, and at Powhatan dam of 320 feet, the country on both sides ranging from 300 to 500 feet.

Mr. A. Resler takes another field, collecting a good deal on Patapsco marsh, just south of the city, also "down the necks," and near Botterill Post-Office, in Howard County, 14 miles from Baltimore.

\section{Order PYGOPODES-Diving Birds.}

Family Podicipide-Grebes.

Colymbus holbœllii (2). Holbœll's Grebe.

"Not uncommon on the Potomac in winter" (A. C., 110), this species has been taken in Lancaster County, Pa., and at other points in Pennsylvania and New Jersey (Birds E. Pa. and N. J., 38), so I presume it occurs all over tide water Maryland. On February 25, 1894, I watehed one for about an hour at Lake Roland where it was swimning around in a hole in the ire, which otherwise covered the lake. Later, when we threw stones at it, it would neither fly nor dive, so we left it.

Colymbus auritus (3). Horned Grebe.

Fairly common in tide-water Maryland during migrations, a number winter with us. Noted from October 7 ('76, Resler) at Back River, to April 23 ('90, Resler), at the same place. April 25, at Washington, D. C. (Richmond). Inland, a young male, shot at New Market, Carroll County, by Dr. H. H. Hopkins, was presented in the flesh on February 21, ' 81 , to the Maryland Academy of Sciences. A pair, male and female, were taken at Hagerstown on April 16, 'S3 (Small), and Mr. Robert Shriver has secured specimens at Cumberland. 
Podilymbus podiceps (6). Pied-billed Grebe.

Common from September 1 ('93) to March 31 ('S8, Resler), a few stay with us to breed, but, as far as I know, the nest has not been found in Maryland. Specimens have been taken on April 28 ('93) and July 31 ('75, Resler), at Back River. At Hagerstown, in June ('So, Small), and near Westminster, early in September ('SO, Fisher) nine, possibly a family, were taken in one day from a mill pond. At Washington, common from August 25 to May (Richmond).

\section{Family URINATORID止-Loons.}

\section{Urinator imber (7). Loon.}

Fairly common during winter on ocean front, Chesapeake Bay, and larger waters of Maryland. In New Jersey it is given as arriving October 3 (Birds E. Pa. and N. J., 39), but I have only spring dates ranging from March 9 ('91, Fisher), at Legoe's Point, to June 17 ('93, J. F. Hargreaves), when a very noisy pair were on the Gumpowder River, near the Pemnsylvania Railroad bridge. Mr. W. S. Walker, of Chestertown, writes me that it is "one of the last birds to leave Chester River." At Washington, from September to April 25 (Richmond). Audubon says (vii, 284): "the Loon breeds in various parts of the United States from Maryland to Maine. I have ascertained that it nestles in the former of these states on the Susquehamna River." Not known to nest here now.

\section{Urinator lumme (11). Red-throated Loon.}

Occasionally taken on our waters during winter. On February 16,1878 , the late $\mathrm{A}$. Wolle presented the Maryland Academy of Sciences with shells taken from the stomach of one of these birds, presumably captured near Baltimore.

"Not uncommon on the (Potomac) River during the winter" months" (A. C., 110). "In the spring of 1 S\$ 2 one was caught in a gill net in the Potomac River, a few miles below Washington, and is now in the possession of Mr. O. N. Bryan, of Marshall 
Hall, Md." (H. M. Smith and W. Palmer, Auk, v, 147). One shot on Chester River wats sent to the Smithsonian for idendification by Hiram Brown, Pomona, Md. (Smith. Report, 1885, 192), "and I also learn from Dr. A. K. Fisher of another, captured on the Potomac, near Fort Washington, October 20, 1889" (Birds Vas., 41).

Family Alcidæ-Auks, Murres, and Puffins.

Cepphus grylle (27). Black Guillemot.

South in winter to New Jersey (Manual, 16). Audubon says (vii, 273), "during severe winters, I have seen the Black Guillemot playing over the water as far south as the shores of Maryland. Such excursions, however, are of rare occurence."

Alca torda (32). Razor-billed Auk.

"Winter visitant on the New Jersey coast; one specimen was secured by Dr. W. L. Abbott as far south as Cape May" (Birds E. Pa. and N. J., 41). "Capt. Chas. H. Crumb informs me that three have been taken near Cobb's Island, two in $185+$ and one in 1557 , one of which is now in my possession" (Pirk's Tar., 1), and sareral more were taken during the winter of 1892-93 (Capt. Crumb in letter to Wm. H. Fisher).

Alle alle (34). Dovekie.

"IRemular winter visitaut along the New. Jersey coast, varying in abundance from year to year" (Birds E. Pa. and N. J., 41). On December 9, 1S77, one was caught alive on the sea beach near Orean City, Mrl., and sent to the Maryland Academy of Science: by Mr. liobert Ifenry, of Berlin, Md. Capt. Crumb has taken two at Cobb's Island.

Order LONGIPENNFS-LOng-Winged Swmmers.

Family Stercoraride-Jaegers and Skuas.

Stercorarius pomarinus (36). Pomarine Jaeger.

Winters on the Atlantic coast from Long Island southward. 
Stercorarius parasiticus (37). Parasitic Jaeger.

Winters along the Atlantic coast from the middle states southward.

Stercorarius longicaudus (38). Long-tailed Jaeger.

Migrates south along the Atlantic coast to the Gulf of Mexico and West Indies.

No doubt all three of the Jaeger's occur off our coast, but we have no record of them.

\section{Family LARID E-Gulls and Terns.}

Rissa tridactyla (40). Kittiwake.

"Very rare winter visitant on the New Jersey const" (Birds E. Pa. and N. J., 42). "About ten years ago the late Ifenry B. Graves, of Berk's County, mounted a young Kittiwake which had been captured near Lancaster City, in midwinter," and "Dr. A. C. Treichler, of Elizabethtown, mentions the species as a straggler in Lancaster Cuunty, Pa." (Birds .Pa., 17). "Captain Crumb reports this species as a rare and irregular winter visitant at Cobb's Island, hut he has never taken a speeimen" (Birds Vas., 41).

\section{Larus leucopterus (43). Iceland Gull (?).}

On November 23, 1893, I saw a pure white gull in the inner harbor of Baltimore City. It came within fifty feet of me at times, as I watehed it for fully half an hour. In reply to a description of this bird, which I sent to Mr. Robert Rirlgway, he writes: "The gull which you think may be the young of $L$. leucopterus, is undoubtedly what American ornithologists here consider and describe as the young of that species. There is a question, however, whether it is not in reality the young of L. kumlieni. There are no present means of settling the question, there being no specimens of undoubted young of $I$. leucopterus in any American collection so far as I know." 
Larus marinus (47). Great Black-backed Gull.

"Rare winter visitant along the New Jersey coast, a ferw, however, probably occur every year" (Birds E. Pa. and N. J., 43). "Ias been taken (including the adult) at Cobb's Island, where on the authority of Capt. Crumb it is not common, though seen every winter" (Bircls Vas., 11); "south coastwise in winter to Florida" (Key, p. T43). On January 27, 1895, at Holly Point, I saw one of these birds circling over the mouth of Grupowder River, but it kept cousiderably out of range.

Larus argentatus smithsonianus (51a). American Herring Gull.

In Baltimore harbor this species is a common winter resident, common over the Basin at Light and Pratt streets, where they live on the refuse. During the latter part of September I could not find any, but quite a number were at hand on October 5, ('94). On May 1, ('95), a number were observed, and on May 6, (95), two were in Canton Hollow. They also occur on all our waters, but not in numbers as they appear in our harbor. "Common in winter at Washington" (Richmond).

Larus delawarensis (54). Ring-billed Gull.

At Washington "seen over the river during the winter months, more frequently than the Herring Gull" (A. C., 10S). "Winters abundantly on the coast of the Middle States, I saw it continually during two winters over the harbor of Baltimore where it flies among the shipping, with Bonaparte's Gulls and several kinds of terns" (Birds N. W., 638).

However the above may have been when Dr. Coues was at Fort McHenry, I have been unable to substantiate the statement, a stray tern being of very unusual occurrence above the Fort, while Bonaparte's Gull, as a rule, liecps below it. My only spring notes are of two near Holly Point over Gumpowder River on March 25 ('94), and a few in the lower harbor on March 
29 ('95), but in fall they are noted near Fort McHenry from September 26 ('94) to November 6 ('94).

Mr. Ridgway writes me: "As to Larus delawarensis wintering near Baltimore, it may occasionally do so, but not in any considerable numbers. Here, on the Potomac, it is not considered a winter resident, though it migrates northward very early in spring," and Mr. C. W. Richmond writes: "Not a winter" visitant at Washington, it was common during March until the 30th, 1S90. Noted from February to April 5, and again in October and November."

\section{Larus atricilla (58). Laughing Gull.}

Common migrant from April $2 S$ ('94, Wholey) to May 22 ('95), and from Septenber 29 ('94) to October 12 ('94). A few may spend the summer with us, two pairs being noted at Patapsco Marsh on July 3 ('93, Blogg).

"One of the most abundant gulls at Cobb's Island, where numbers commence to breed about the 20th of June" (Birds Vas., 41). I have been told they breed at Chincoteague Island, and from the fact that I saw a few flying north in the morning and south in the eroning over Chincoteague Bay, in Maryland, I presume they do, though a search of ten days (June 5 to 14 , '94) failed to locate a breeding site on the ocean front of Maryland, and I also failed during two seasons ('92 and '93) to locate a breeding site on the Chesapeake, though frequently told of them by the fishermen, and frequently seeing paired birds.

\section{Larus philadelphia (60). Bonaparte's Gull.}

A tolerably common migrant, noted from March 24 ('94, Fisher) to Nay 17 (9:3), and from October 5 ('94) to November $9(92$, Resler); a few may also winter with us (Birds N. W., (33S). While this species maly come up the harbor with the Herring Gulls, I do not think it ever comes beyond the broad water at Broadway Ferry. At Washington they are given as "comparatively common in August and September" (A. C., 108). 
Gelochelidon nilotica (63). Gull-billed Tern.

"Rare visitant along the New Jersey coast, where it is reported to have bred formerly ('As late as 1886, according to Mr. H. G. Parker' [O. and O., 1856, p. 138])." (Birds E. Pa. and N. J., 44.)

On May 19, 20, 21, 1892, Mr. W. H. Fisher noted this species at Cobb's Island, Va., where, Mr. H. B. Bailey says, "a few pairs were seen, but they had not commenced to breed during my visit, May 25 to 29, 1875. They nest here sparingly, however, as I had a set of their eggs sent me which were laid the last of June" (Auk, i, 24-28), and, May 14 to 28, 1S94, they "seem to be rapidly diminishing in numbers, being far less numerous than I observed them on two previous trips in 1891 and 1892, when I was collecting in vicinity of Smith's Island, Va." (E. J. Brown, Auk, xi, 259). Casual at Washington (Richmond).

Sterna tschegrava (64). Caspian Tern.

Rare migrant along the Atlantic coast.

On July 4, 1Ss0, Mr. Robert Ridgway found two nests with two eggs in each, they were at opposite ends of Cobb's Island, and about ten miles apart (B. N. O. C., v, 221-22-23). "Capt. Crumb has found three sets of eggs in July" (Birds Vas., p. 42).

"Hon. J. J. Libhart, in his ornithological report, published in the history of Lancaster County, records the capture of two of these birds on the Susquehanna at Marietta, Pa., on September 21, 1847" (Birds Pa., 19).

\section{Sterna maxima (65). Royal Tern.}

"They have always been found breeding on a small sand bar off Cobb's Island, but it was washed away during the winter of 1874-75, and although the birds were flying about (May 25-29, '75), they had not chosen any spot on which to breed; but they undoubtedly did so later" (H. B. Bailey, Auk, i, 24-2S). 
On July 4, 1880, Mr. Robert Ridgwaly saw an immense colony there (B. N. O. C., r, 221-22-23), and "Captain Crumb has found eggs in the latter part of June" (Birds Vas., 42). "Rare straggler on the New Jersey coast during summer" (Birds E. Pa. and N. J., 45).

\section{Sterna forsteri (69). For'ster's Tern.}

"It is the commonest tern in winter and during the migrations in the harbor of Baltimore" (Birds N. W., 679). On March 4, 1893, during a severe snow storm, I saw several terns flying over the chamnel off Sparrow's Point, which I believe were of this species, but they did not come close enough to be positively identified.

They have been taken near Washington, D. C., and have been found quite abundant over the lower Potomac by Mr. P. L. Jouy (Field and Forrest, vii, 29).

On the evening of June 5, 1894, at North Beach, about ten miles south of Ocean City, MI., I saw some boys who had gathered about 200 "Striker" eggrs, and were proceeding to cook same for their supper; they had also shot a number of birds which, on examination, I found to be all For'ster's Terns. Next day, June 6, 1S94, I visited a marshy island with probably 2000 terns over it, and as far as I could observe all were forsteri. Here I noted 12 nests with 3 eggs, 19 with 2 and 41 with 1 ; how many without eggs $\cdot$ I am unable to say.

On June 7 I visited two other much smaller "tumps" about three miles distant; about 200 birds here, on one there were 7 nests with 1 egg each, and on the other 7 with 1 , and 1 with 2 ; this was evidently where the boys had been, as innumerable nests were empty. On June $10 \mathrm{I}$ again visited all three of these "tumps" and on the larger one noted 7 nests with 3 eggs, 7 with 2 , and 19 with 1 , the number of unocupied nests being greater than before. On the smaller "tumps" I saw respectively 1 of 2 , and 6 of 1 ; and 3 of 2 and 4 of 1 ; and more unoccupied nests. Here the birds were much fewer than hefore, while at the largest "tump" there appeared to be more than 
on the 6th. These nesting places had been visited by other parties between my visits.

Sterna hirundo (70). Common Tern.

"In North America chiefly confined to the Eastern Provinces, breeding variously throughout its range" (A. O. U.). Apparently migratory, three specimens were taken on May 6 ('76, Resler) out of a number seen at Patapsco marsh; and on May 17 ('93), one was shot at the same place. On September 1 ('93, A. Wolle), four were shot out of about fifteen at Gunpowder marsh, these I examined.

Sometimes common, but an irregular migrant at Washington (Richmond).

\section{Sterna paradisæa (71). Arctic Tern.}

Breeding from Massachusettes northward, this species comes south in winter along the Atlantic coast at least as far as Virginia.

\section{Sterna dougalli (72). Roseate Tern.}

This southern species, going regularly north in summer to Maine, "doubtless breeds" at Cobb's Island (H. B. Bailey, Auk, i, 24-28), and is a "rare straggler on the New Jersey coast during summer ; formerly it is reported to have bred in considerable numbers" (Birds E. P. and N. J:, 47).

\section{Sterna antillarum (74). Least Tern.}

A summer resident in restricted localities, this species is usually seen during migrations.

On June 13, ('94), I visited a nesting colony at the juncture of Miles River with Eastern Bay, where, on a small island, I found four sets of three; twelve of tro, and eight single eggs; how many other nesting hollows it is impossible to say, as they are so slight they show no signs of a nest until an egg is deposited. During the fall of 1893 , this species was noted at Lake Roland on August 19 and 20, and September 3 and 4 (Fisher). 
Sterna fuliginosa (75). Sooty Tern.

North to the Carolinas and casually to New England; "there is a specimen from Baltimore in the National Museum at Washington, obtained from the late Mr. A. Wolle (Robert Ridgway).

"Dr. A. C. Treichler mentions it as a straggler in the neighborhood of Elizabethtown, Lancaster Co., Pa." (Bircls Pa., 23).

\section{Hydrochelidon nigra surinamensis (77). Black Teru.}

While this species is locally common over the whole of North America, I can find but few records for the vicinity of Maryland. At Washington, it is given as "less numerous than the Least Tern, found at same seasons" (A.C., 109) "Not uncommon in the early fall at Cobb's Island, Va. It has been seen there in the breeding season, but is not known to breed" (Birds Vas., 43). "Transient, occurring on the New Jersey coast, but much less abundantly than formerly. Mr. Scott states that it arrived at Iong Branch in 1879 , about June 11, and soon became common ; althongh it rentained all summer, it was not known to breed (B. N. O. C., '79)' (Birds E. Pa. and N. J., 48).

The Smithonian acknowledged "Skin of short-tailed Tern, from Potomae River, Thos. Marron" (Smith. Rep. 1S91, 793).

On May 17, 1593, Alex. Wolle shot one on Patalpsco marsh, and on August 25, 1893, Richard Cantter shot another near Upper Marlborough; both of these I examined in the flesh.

\section{Family Rynchopid Æ-Skimmers.}

Rynchops nigra (80). Black Skimmer.

This strictly maritime bird of our southern coast goes regularly north to New Jersey, where it is recorded from June 10 until September 25 (Birds E. Pa. and N. J., 48). On .June 19, 1850, a specimen was presented to the Maryland Academy of Sciences, presumably taken near Baltimore.

"Individuals were once seen by ourselves on the Potomac, 
some distance below Washington, September 8, 1858" (A. C., 109).

$\Lambda$ t Cobb's Island, Va., from May 25 to 29,1875 , they were found in flocks of 20 or 30 , as they do not breed until the last of Jume (H. B. Bailey, Auk, i, 28), and just before dusk on May 20, 1891, four were seen there (Fisher).

"Common at Smith's Island, Va., where we got three on May 15, 1894, but they had not begun to breed by the 26th when we left" (C. W. Richmond).

\section{Order TUBINARES-TubE-Nosed SwImmens.}

Family Procellarinde-Shearwaters and Petrels.

Puffinus major (89). Greater Shearwater.

"Atlantic coast generally. A rare straggler to the New Jersey coast" (Birds E. Pa. and N. J., 49).

Puffinus auduboni (92). Audubon's Shearwater.

Atlantic coast from New Jersey southward, breeds in the Bermudas and Bahamas (A. O. U.).

\section{Puffinus stricklandi (94). Sooty Shearwater.}

North Atlantic, south to the Carolinas, breeding far north. No doubt all three occur off our ocean front, but as there are no observers there, their presence with that of other of our ocean birds has not been recorded.

Oceanodroma leucorhoa (106). Leach's Petrel.

On June 11, 1995, while fishing on Little Gull Bank, about three miles out from Ocean City, a pair of these birds came and circled round our boat for a few minutes. I have also noted them further out, off our Maryland coast, on several occasions during the month of August, when they followed the vessel generally in company with Wilson's Petrel.

Occasionally heavy easterly gales drive them inland; at Washington, D. C., "one of several shot in August, 1842, is 
now in the National Museum, also another taken near the Navy Yard Bridge, on .June 5, 1891, by Wm. Bayley. Wm. Palmer has two; one was shot from a bunch of three or four on Lugust 29,1893 , the other was captured alive in a house on Capitol Hill a few days later" (Richmond).

\section{Oceanites oceanicus (109). Wilson's Petrel.}

I have been greatly interested in watching these birds as they flew round the vessel, on several sea trips I have made. Under date of August 20, 1SS4, I find the following: "Cleared the eapes last night at 11.30 P. M., and this morning we have the petrels, which stay with us all day, the Maryland shore being in sight. One is partly albino, having a white breast, belly and back, separated from the usual white by a sooty line."

The only inland record I can find is "one taken many years ago and presented to the Smithsonian" (A. C., 110). "This was shot on the Potomac River about 1859" (Richmond).

\section{Order S'TEGANOPODES-Totipalmate Swmmers.}

Family Sulide-Gannets.

\section{Sula bassana (117). Gannet}

Occasionally taken on the Chesapeake, three ipecinens so recorded have been presented to the Maryland Acadeny of Sciences, where two of them are at present, the other, now in the Johns Hopkins University, taken many years ago at ('hestertown, was presented by Mr. Colin Stam(-en:) through Mr.J.J. Thomsen. On April 21, 1894, one was taken in Rock Hall Cove and forwarded alive to the Aeadeny by Dr. A. P. Sharp. Mr. John Murdock presented a mounted specimen on June (;, 1s92, referring to which he writes me: "The bird I presented to the Maryland Academy of Sciences was killed a short time previously in the lower part of the Chesapeake Bay, near Mobjack Bay; I have never seen them above that point; gencrally they go in pairs." 
"I found the remains of one on Smith's Island, Va., in May, 1s:4. It had been dead about a month, possibly more" (Richmond).

Family AnHingrde-Darters.

Anhinga anhinga (118). Anhinga.

In the old collection of the Maryland Acalemy of Sciences was a mounted specinen of the Anhinga, which Prof. Uhler says, came from the Pocomoke River, but owing to the vicissitudes through which the Academy has passed, I have been unable to find the record of its acquisition.

\section{Family Phalacrocoracida-Cormorants.}

\section{Phalacrocorax carbo (119). Cormorant.}

Audubon says, "it is rarely seen further south than the extreme limits of Maryland, but from Chesapeake Bay eastward it becomes more plentiful" (vii, 418). A specimen may occasionally visit us with the following species, as it goes casually south as far as the Carolinas (A. O. U.).

Phalacrocorax dilophus (120). Double-crested Cormorant.

Regular, but not a common winter visitant near Baltimore. Further down the Chesapeake, and on Chincoteague and Sinepuxent Bays, it is more numerous. Uncier date of April 13, 1893 , Mr. Wm. S. Walker, of Chestertown, writes me: "The only Cormorant I ever had in hand, I killed some five or six years ago at Hail Creek, at the mouth of Chester River. I have since that time seen one or more of the birds sitting on buoys in the bay between here and Baltimore." The specimen mentioned was in the old collection of the Maryland Academy of Sciences.

At Ocean City single birds flew northward on June 8 and 10 ,'94.

"One wats detected in the District of Columbia many years ago" (A. (., 10S). Mr. Geo. W. Duvall sent a specimen from Annapolis to the Smithsonian (Snith. Rep., '72, 57). 


\section{Family Pelecanide-Pelicans.}

Pelecanus erythrorhynchos (125). American White Pelican.

Rare straggler. "There appear to be three well authenticated instances of the capture of this bird in our vicinity. 1. Near Alexandria, Va., April, 1861, h C: Drexler, and presented to the Smithonian. 2. Opposite Washington, on the Virginia bank of the Potomac, fall of 1864; shot by John Ferguson, and seen and identified by several persons who have communicated the fact to us. 3. Near Alexandria, Va., October, 1878 , killed br John llaxhnrt, and seen by a gentleman connected with the National Museun" (II. M. Smith and W"m. Palmer, Auk, v, 147). "A stray Pelican at Oakland, Md., by Sportsman," is recorded (Auk, iv, 345).

\section{Pelecanus fuscus (126). Brown Pelican.}

Exclusively maritime, "from 'Tropical America to the Carolinas" (A.O.U.). Captain (rumb moted them at ('obh's Island, in the fall of 1881 (Birds Tas., 44), and "Turubull records one" specimen shot off Sandy Hook in 1837, in summer" (Birds E. Pa. and N. J., 52). In the old collection of the Academy was a specimen from the lower Potomae (Uhler).

\section{Order ANSERES-Lamellirostral Swmmers.}

Family Anatide-Ducks, Geese, and Swans.

Merganser americanus (129). American Merganser.

This, the largest of the "fishermen," is a winter resident, from Sept. 29, ('94), to March 29, ('93 Resler); common on our larger waters.

On March 24 ('95) I watehed a bunch of eight for quite a while on the Gunpowder Falls; they were diving in the swift running stream, just above the dead water of Loch Raven. Mr. Shriver says, "something of" a rarity at Cumberland, but I have seen a number of them years ago ; none lately."

"In the ornothological report of the late Judge Libhart, published about twelve or fifteen years ago in the history of Lan- 
caster county, the Goosander, also the Red-breasted and Hooded Mergansers are all mentioned as breeding in Lancaster County." (Birds Pa. 32).

Merganser serrator (130). Red-breasted Merganser.

From the number brought to market, this is the most common "fisherman" shot on the Chesapeake and its tributaries during the gumning season. Possibly it also stays here to breed, as Mr. W. N. Wholey shot a female on July \&, 1892, at Egging Beach Island, near Ocean City. It was in good condition and not crippled in any way, but the breast feathers were so few and so worn that there can be no doubt of its having nested. Two others flushed at the shot but were not sccured. Loch Raven (Chas. E. Dukehart).

Lophodytes cucullatus (131). Hooded Merganser.

Common on the arms of the Chesapeake during gunning season; this species is also to be found generally dispersed over the state, even on small waters. Several flocks were seen on the Potomac, about two miles below Knoxville, on November 5 ('93, Fisher). Loch Raven (Dukehart).

It probably breeds, for on June 7 ('94) I noted one at Whittington's Point, near Ocean City, and Dr. Warren says: "I have an adult female, taken June 23, 1890, in Chester Co., Pa., where this Merganser is seldom seen in summer" (Birds Pa, $345)$.

Anas boschas (132). Mallard.

Common winter resident, from October 7 ('93) to April 14 ('94, Fisher). Mr. W. S. Walker, of Chestertown, says: "the first ducks to arrive here are the 'flat fowl,' that is those feeding on the flats of the Bay shore, they are Black Ducks, Mallards, Graybacks and Sprigtails." A number have been shot on Loch Raven (Dukehart), and on November 4 ('93, Fisher) they were very numerous on the Potomac between Knoxville and Brunswick. Under "County news," on April 13, 1894, the Sun paper salys: "Gumners in Alleghany county 
are having a fine time, as the streams are covered with Mallards." On April 5, 1S95, a pair were shot at Cumberland (Zacharia Laney).

\section{Anas obscura (133). Black Duck.}

Common in tidewater Maryland during the gumning scason, quite a number remain during summer and breed. Numerous in the vicinity of Baltimore from August 28 ('93, Fisher), to May 6 ('93, Gray). I observed this species in 1894, at Ocean City, as follows: On June 5 a pair; on the 6 th a pair; on the 7 th $3,2,3,1,3$, and also a pair with small young on Chincateague Bay about two miles from shore, where it was so rough I could not count the young. On. the 10th my man at last succeeded in finding a nest, but it only held the two half shells of an egg, one inside the other.

At Loch Raven, on April 7, ('95), I watched 20 birds for some time, they were feeding in shallow water like tame ducks, and while they kept in a close bunch, were mated, each pair distinctly keeping together.

\section{Anas strepera (135). Gadwall.}

While a few no doubt winter with us, the species seems to be fairly numerous in November, and again in April; though it is rather difficult to get statisties, our market gumners clasing this and the females of three or four other species as "gray ducks," and our amateurs as "trash ducks." On November 22-3, 1S:14, about 20 were shot at Spry's Island. It Washington, D. C., they are given as common from September to April (Richmond).

From the Sun I take the following: "Williamsport, Mr. April 9, 1895. Wild ducks are plentiful along the I'otomae, above this place. From the old Sharpless warehouse up, to Big Pool, flocks of Gray Mallards abound. 'There, the sportsmen say, are rare, and it is unusual to see so many of them along the river." 


\section{Anas penelope (136). Widgeon.}

This Old World species is given as "rare or casual along the Atlantic coast of North America" (Key, 694).

Several specimens have been taken within our state. One found in market, at Washington by Mr. C. Drexler, in the spring of 1963 , thot near Alexandria, Va, is now in the National Nuseum (A. C., 10:3-4). On .July 11, 1890, an adult male was found in Washington Market, New York. It "had been shipper from Baltimore and doubtless was shot on the Chesapeake Bay," and is now in the American Museum of Natural History, N. Y. (Edgar A. Mearns, Auk. viii, 204). "On the property of the Carroll's Island Club, Baltimore County, Mr. Wm. Carpenter, on February 25, 1890, killed one of this species from a bunch of Baldpates. This bird has been mounted and is at present in my care" (L. S. Foster, Auk, viii, 283).

At a stated meeting of the Maryland Academy of Sciences, held April 5, 18s0, Mr. Arthur Resler referred to a specimen of the European Baldpate which he had examined at the taxidermist store of $\mathrm{A}$. Wolle, where it had been sent to be mounted. It was shot on the Atlantic coast of Maryland (Minutes of Maryland Academy of Sciences, 1880, 280).

Dr. Wm. II. Poplar has a specinen in his house at Havrede-Grace. He told me that he shot that "Red-headed Baldpate" in November, 1881, and considered it a cross between a Redhead and a Baldpate.

\section{Anas americana (137). Baldpate.}

Common during winter, this species, as with nearly all of on ducks, is most numerous during fall and spring flights.

() September 23 (93, Fisher) several bunches were noted at Sparrows' Point, and the last Baldpate was shot at Grace's Quarter on April 8 ('S6, Ducking Record).

Inland, a male was taken in October 's , at Ridgley's Dam in Dulaney's Valley (Fisher). On November 4, '93, several bunches were on the Potomac, near Brum-wick (Fisher), and it has been taken at Cumberland (Shriver). 
On October 3, 'S9, I witnesed a remarkable instance of the' well-known sailing power of a dead duck, if shot in the heart with its wings spread. Fishing near Maxwell's Point, my attention was taken by several shots on Saltpeter Creek, and looking in that direction I noticed a duck coming down the wind, which was blowing fresh from a few points $\mathrm{N}$. of $\mathrm{W}$. As it got closer I noticed it was sailing, wings and neck at full streteh; when first seen it was well up and over the lam!, but gradually descending, it struck the water with a splash about one-quarter mile from our boat and near the centre of the river, or about two-aud-ahalf miles from where it was shot, the neek being about a nile across and Gunpowder River about three miles wide at this point.

\section{Anas crecca (138). European Teal.}

One shot on the Potomac River, near Washington, in April, 1Sss, was presented to the National Musemm (Ank, iii, 13!'). It was an "adult male, shot by Henry Marshall, of Laurel, Md." (Smith. Report, '86, 154).

\section{Anas carolinensis (139). Green-minged Teal.}

Common during spring and fall migrations, a number stay in tidewater Maryland during mild winters. It is not so numerous as the following species, with which it arrives and departs. Mr. W. S. Walker, of Chestertown, writes me: "Among the last to leave Chester River is the Teal, or Partridge" Duck, a little brown duck."

\section{Anas discors (140). Blue-winged Teal.}

Usually seen with, or in the same places as the last mentioned, and during the same time of year. A bunch of 15 were noted in Bear Creek, on August 20 ('93, Fisher). The latest date is May 7 ('90, Resler), when one was taken on Patapsco Marsh.

On September 17, '93, I saw a bunch of 10 on Loch Raven, in Dulaney's Valley. 'They were standing at edge of water, 
and allowed me to walk up opposite them. After observing them through a field glass for some time, I flushed them with a stone and they flew up stream a short distance. Following them in full view, I again got opposite and sat down, they appeared quite tame, and although my dogs paddled round in the water near them, they did not fly until I again threw a stone among them; evidently they had just arrived from the north and were tired ont.

At Hagerstown, during April ('80, Small), and at Cumberland (Shriver).

\section{Spatula clypeata (142). Shoveler.}

Quite a number of "Broadbills" are shot during our gunning season, but they camnot be said to be common. I have no characteristic dates. A pair were taken at Gunpowder River, on March 27, (95, Resler). Not uncommon at Washington during winter (Richmond); at Cumberland (Shriver).

\section{Dafila acuta (143). Pintail.}

Common during fall and spring flights, I believe some stay with us during mild winters. Mr. N. S. Bogle, of Eastern Neck Island, writes me, that "a flock of 15 Sprigtails arrived in Chester River, on September 13 ('93), these were the first ducks." They are noted from that on to October 28 ('93). On March 4 ('94, Fisher), about 20 were in a bunch on Bird River, and several were taken on Choptank River on April 7 ('94). Loch Raven (Dukehart).

\section{Aix sponsa (144). Wood Duck.}

Sparingly resident, this species is numerous in spring and fall. While usually seen "down the necks," single birck or pairs are often flushed from pools on very small rums, the principal attraction apparently being oak woods. Some yeal's ago, in May, on IIog (reek, a female and eight young were observed (Fisher), and Mr. P. A. Bowen, writing from Aquaseo, Prince George's County says, "resident, there are now in this neigh- 
borhood three birds, hatched in confinement from eggs taken from a hollow tree."

Resident but not common, at Washington (Richmond); Hagerstown (Small); Cumberland (Shriver).

\section{Aythya americana (146). Redhead.}

Common during winter in tidewater Maryland. They arrive earlier, but the first date I have is October 3 ('89), when an enormons number of ducks were "bedded" on Gumpowder" River, below Naxwell's Point, quite a large number of them being Redheads. As late as May 2 ('95, 'Tylor), about 150 were on Gumpowder, near Magnolia, in five or six small bunches. Inland, they are numerously recorded. Alout 10 years ago 500 or 600 stopped for a few days on Lake Roland (Fisher); on March 29 ('91), several small bunches were on Loch Raven (Wholey), and a number have been taken in Dulaney's Valley (Dukehurt). On November 4 (9:3), a f'ew were on the Potomate near Knoxville (Fisher), and they are given as oceasional at Cumberland (Shriver).

\section{Aythya vallisneria (147). Canvasback.}

Still a common winter resident of tidewater Maryland, though most numerous during fall and spring flights.

On October 3, 1889, quite a large number where with the Rertheads, Blackleadk, etc., berded on Gumpowder River, and they have been taken at Grace's Quarter from October 21 ('so) to April 4 ('S6, Ducking Record), but no doubt some remain later.

Aythya marila nearctica (148). American Scaup Duck.

Common on the Chesapeake aud its numerous arms during winter. On October 3, 1889, a number were with the other ducks on Gunpowler Iiver, and on March 25, 18:14, I watched a most affectionate pair, male and female, for some time at Cedar Point. It also occurs inland, about 200 were on Lake Roland October 29 ('y2, Fisher). Dr. ()wings, of Ellicott 
City, shot one on his ice-pond in November, 1893. Loch Raven (Dukehart); Harpers Ferry, a bunch of six, Norember 6 ('93, Fisher); Cumberland (Shriver).

Aythya affinis (149). Lesser Scaup Duck.

Arriving and departing with the former species, this is much the more numerous, and both with the following, are generally classed together by gumer'. At Cratee's Quarter, "Blackheads" are recorded as being shot from Octoher 3 ('S9) to April 8 ('S6) and, as with all other ducks, the "Blackheals" are most numerous during the fall and spring flights. On April 2 ('90, Richmond) one was taken near Washington. On April 5 ('95) one was taken at Cumberland (Zacharia Laney).

\section{Aythya collaris (150). Ring-necked Duck.}

Not very numerous. I presume it arrives with the other "Blackheads." All the notes I have range between March 8 ('94), when one was shot at Bush Rirer by Mr. Melville Wilion, who called it a "Creek Blackheal," anci April 4 ('91, Wholey), when one was shot in the open river below Fort McHenry.

Glaucionetta clangula americana (151). American Goldeneye.

Common in tidewater Maryland, from October to April, I have not any extreme dates. Mr. Dukehart has frequently shot them at Loch Raven and they have been taken at Hagerstown on December 28, 1879, and April 15, 1883 (Small).

\section{Glaucionetta islandica (152). Barrow's Golden-eje.}

This northern species coming sonth in winter to New York, has in one recorded instancestraggled as far sonth as inaryland. "I female shot on the Potomak live", opposite Wakhington, Nov. 22, 1859, by C. Herbert; is now in the collection of J. D. Figgens" (C. W. Richmond, Auk, viii, 112). 
Charitonetta albeola (153). Bufflehead.

Common in winter, arriving the latter part of September, one was at Patapsco marsh on May 7 ('90, Resler).

On February 15, 1895, just af ter the blizzard, one came up the harbor into the upper basin and stayed round off Bowley's wharf for a long time. Inland, it has been taken at Sandy Springs in April (Stabler); a pair were seen near Harper's Ferry on October 10 ('9:3 Fisher), and they have been shot at Cumberland (Shriver).

\section{Clangula hyemalis (154). Old Squaw.}

Common in winter on the Chesapeake; I noted one at Fort MI.Henry on Oetober 27, (94), and they remain with us until late in April. On Mareh 4 , 1855, there were several hundred in the mouth of Chester River on broul water, nearly all in pairs, but occasionally a few males were in a bunch by themselves. As the steamboat was ruming before a terrific snow squall, we got quite close before they flushed. Often they dived and on coming up appeared to he fying before they emerged. On the 6th it was blowing a gentle breeze, and although they were extremely numerous, we did not get close to any.

Loch Raven (Dukehart).

Camptolaimus labradorius (156). Labrador Duck.

Now extinct, they were apparently quite numerous in Audubon's time, for he says (vi, 329): "The range of this species along the shores row not extend further southward than ('hesapeake Bay, where I have seen some near the influx of the St. James River. I havealso met with several in the Baltimore market."

Somateria dresseri (160). American Eider.

"Winters southward to Delaware" (Chapman, 117). "In the old collection of the Maryland Acadeny of Aciences was a specimen from Maryland, collected at Pammikey Neck, below Marshall Hall, by Mr. Chapman" (P. R. Uhler). 
Somateria spectabilis (162). King Eider.

"South casually to New Jersey, in winter" (Manual, 110). A young bird of this species was obtained at Cobb's Island, Va., by Captain C. H. Crumb, on December 19, 1899" (Birds Vas., 48).

Oidemia americana (163). American Scoter.

Common during fall and spring flights, on ocean front and broad waters of tidewater Maryland, a few may winter. On November 4, ('94) four spent the evening in the basin, and on November 17 ('77), Major Hill presented a specimen in the flesh to the Maryland Academy of Sciences. On March 8 ('94), one was in Saltpeter Creek, and they were numerous on open water. Late in April, and early in June they are reported as being fairly numerous at Havre de Grace.

During Christmas week ('90) they were fairly common at Eastville, Northampton County, Va.(Ridgley Duvall, Jr.).

Oidemia deglandi (165). White-winged Scoter.

Fairly common on the Chesapeake during spring and fall, this species may winter with us. On September 12 ('94), four were noted in Chester River by Mr. E. Speddin of the tugboat Chicago, and on November 6 ('94), a pair were shot down the Necks, which I saw in market the next day.

On Mareh 6 ('93), I saw three in a bunch off Love Point lighthouse, at the mouth of Chester River, they did not flush until the steamboat was close to them, in marked contrast to the South Southerlies; on May 12 ('94, Fisher), 3 were at the mouth of the Patapsco.

\section{Oidemia perspicillata (166). Surf Scoter.}

Arriving and departing with the others, I can give no characteristic dates. The three heing as a rule classed as "tar-pots" or "bay muscoveys" and not being considered good for anything" are seldom shot. 
"Common winter resident off the New Jersey coast from October to late in April. Apparently the most abundant species of Scoter" (Birds E. P. and N. J., 59).

\section{Erismatura rubida (167). Ruddy Duck.}

Common during spring and fall. I have no winter dates, though possibly it remains with us. A bunch of 4 or 5 was seen in Baltimore harbor close to the Pennsylvania Railroal pier, at the foot of Caroline street, carly in the morning of September 25 ('94) by Mr. E. Speddin, of the tughoat Chicago, and they were numerous until November 11 (') Patapseo Marsh). On March S (94), between two and three hundred were bedded off Grace's Quarter, and on .June (t) (9), a lunch of six were still off' Ocean City.

Fairly common on fresh water, this species has been taken as follows: On October 29, '92, two at Lake Roland (Fisher), and three from a bunch of five at Powhatan I)am (Gray). Several have been shot at Loch Raven (Dukehart), and on November 5, '93, a pair were on the Potomac near Knoxville (Fisher).

Chen hyperborea nivialis (169a). Greater Snow (toose.

"Along the Atlantic coast it may be concidered rare" (Birds N. W., 549). On April 26, '80, Mr. Mitchell, of Cecil Co., presented a specimen to the Maryland Academy of Sciences; at Legoe's Point one was noted on March 10, '90, and early in October, '90, two flew over the bridge at Sparrows' Point, about 40 feet up (Fisher).

\section{Anser albifrons gambeli (171a). American White-fronted Goose.}

Rare straggler. One shot on the Potomac in 1856 was bought in the Washington market for the Smithsonian (Smith. Rept., '56, 68).

On Nov. 12, '92, a young male was shot at Grace's ( uarter, Baltimore County, by Mr. Charles D. Fisher, and by him pre- 
sented to the Maryland Academy of Sciences. It was flying alone and came in to decoy's answering the usual goose call.

\section{Branta canadensis (172). Canada Goose.}

Common winter resident: On October 4 ('94), four were seen sitting on a $\log$ at Spry's Island, by George B. Fowler, and on the 20th ('9 $\left.\frac{1}{2}\right)$, they were "exceedingly numerous in Day's Hollow on Gumpowder River; when they Hew up it sounded like thunder; a few days later they had all left" (Edw. A. Robinson). They remain with us during winter in rather more limited numbers, and are again numerous in early spring, the latest record being April 10 ('90, Resler).

Inland, they are liable to be found anywhere in the state during spring and fall flights. On November 5 and 6 ('93, Fisher), quite a number were on the Potomac between Knoxville and Brunswick, and on April 15, 16 and 17, ('S3, Small), the reservoir at Hagerstown "fairly swarmed with them."

In New Jersey "some linger as late as May 12 " (Birds E. Pa. and N. J., 60).

Branta canadensis hutchinsii (172a). Hutchin's Goose.

"South in winter through United States, chiefly west of the Alleghanies" (Manual, 117). "A goose, from its small dimensions and 16 tail feathers apparently referable to this sub-species, was taken at Cobb's Island, in the winter of 18S5-S9 by Capt. Crumb" (Birds Vas., p. 49).

\section{Branta bernicla (173). Brant.}

Arriving and departing at about the same time as the common goose, this species is not so abundant. Most numerous during spring and fall migrations, quite a number as a rule winter with us, but I have no characteristic dates.

\section{Branta nigricans (174). Black Brant.}

"Very rarely straggling to the Atlantic coast" (Manual, 11S), this species has been taken on the New Jersey coast (Birds 
E. Pa. and N. J., (60) and "Capt. Crumb informs me that it is usual for one or two to le ohtainerl at Cobl,'s Island nearly every winter" (Birds Vas., 49).

Olor columbianus (180). Whistling Swan.

Common winter resident on the broad waters of tidewater Maryland, and during spring and fall llights liable to be seen anywhere in the state. On September 26 ('93), one was shot on the Potomae near Weverton, by John Lcopold. On November 4 ('93, Fisher), several bunches were at the same place, while on April 15, 16 and 17, ('S3), two were on the reservoir at Hagerstown (Small).

While swans are more or less difficult to shoot, they of ten "bed" on broad water out of range in large numbers. On January 20, '94, I counted $\$ 2$ standing on ice at the mouth of Gumpowder River, and a week later 194 ma the water at the same place, where I an told they at times appear in greater numbers.

Olor buccinator (181). Trumpeter Swan.

Casual on the Atlantic c'oast. "In Turnbull's list (Birds E. Pa.) this species is included on the authority of reliable sportsmen who have shot it on the ('hesapeake Bay" (Birds N. IV., 545).

In the Oologist, Vol. vi, 15-16, is quite an interesting article on the taking of one from a bunch of 12 or 15 on Slaughter Beach Marsh, Del., by Mr. G. L. Stevens, of Lincoln, Del., on Norember? ('s?), at which time they were fying southward.

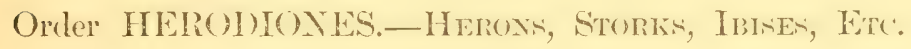
Family. IBIdIde-Ibises.

Guara alba (184). White Ibis.

Regularly north to the Carolinas in summer and casually to Long Island; two have been recorded from New Jersey and one from Pennsylvania (Birds E. Pa. and N. J., 61). 


\section{Plegadis autumnalis (186). Glossy Ibis.}

"Warmer parts of the Eastern Hemisphere, also more southern portions of the Eastern United States" (Manual, 12t). "At very irregular periods in the spring, small flocks have been seen on the coast of the Middle States, and on the Eastern Shore of Maryland and Virginia," and one taken near Baltimore, and two in the District of Columbia in 1817 are mentioned (Water Birds of N. A., i, 95-6).

\section{Family CiCONIID $\approx$-Storks.}

Tantalus loculator (188). Wood Ibis.

Regularly "morth to the Carolinas, casually to Pennsylvania and New Jersey" (Key, 653). "The late Julge Libhart, in his ornithological report of Lancaster Co., Pa., says : "I obtained a fine specimen of this species shot from a troop of 10 , by Mr. M. Ely, on the Susquehanna, in July 1862," and "Dr. A. C. Treichler, of Elizabethtown, has specimens in his collection which were shot in Lancaster Co. in the early part of July, 1883, shortly after" severe storms" (Birds Pa., 53). "On July 2 1893, Mr. Fred. Zoller brought me 2 females, adult and young; they were killed on the flats a short distance from the $W^{\text {atshing- }}$ ton monument, and on the Maryland side of the Potomae" (E. M. Masbrouck, Auk, x, 92). Two were taken near Bloomery, Hampshire Co., W. Va., by Dr. A. Wall (American Field, xxii, 82).

Mr. Robert Shriver, of Cumberland, writes me: "About 30 years ago I shot a Wood Ibis. This was the only specimen I ever saw; it was first seen by myself near the Potomac River bank, but before it was captured a dozen hunters were after it and it evaded them for several days. I always valued this specimen highly and an sorry it has gone "the way of all flesh.",

On October 15, 1893, Mr. Jacob F. Saylor described a bird to me taken during "wheat harvest" at the bend of the Gumpowder Falls in Dulaney's Talley, Baltimore Co.; from his description, and later corroboration by $\mathrm{Mr}$. Dukehart, I am satisfied it can be no other than this species. 


\section{Family ArdeId £-Bitterns and Herons.}

\section{Botaurus lentiginosus (190). American Bittern.}

Fairly common during spring and fall, a few spend the summer with us and possibly breed. It may also stay over winter during mild seasons. From March 25 ('93, Gray) they are numerously noted until May 5 (93, Resler), and in fall from September 1 ('91, Tylor), when one was taken at Tuckahoe Creek until October 10 ('94), when one was caught alive by Mrr. Jacob Kirkwood early in the morning in front of No. 103 Elliott street in Baltimore City. 'This he kindly kept in a box until I examined it. It was an ordinary sized dark plumaged male.

Mr. J. E. Tylor supplies me with the following items: "Between the 20th and 30th of August, 1 S:91, I killed a male Bittern in the Adkin's wookls, one mile south of Easton, and mounted same. On the first day of September, 1891, Dr. E. R. 'Trippe, of Easton, in company with A. G. Pascault, of the same town, shot a male Bittem in Tuckahoe Creek, five miles below Hillsboro; this I also mounted. (On July 11, 1891, on Hog Creek, Gunpowder River, I flushed one from the marsh, but did not secure it."

"Mr. William H. Buller, residling at Marietta, Lancaster County, Pa., in a letter dated July 29, 1589, addressed to me, writes as follows: 'I am inclined to believe that the American Bittern breeds in the vicinity of Schock's Mills, a few miles west of Marietta; while I have never found its nest, or seen its young, yet I have so frequently seen the bird in that vicinity during the summer, that $\mathrm{I}$ think it probable that it breeds there", (Birds Pa., 55).

Dr. Coues, speaking of the District of Columbia, says: "Resilent and rather common" (A. C., 100), and "I have priocured it in January at Washington" (Birds N. W. 529). "Rather common from August to April at Washington" (Richmond). 


\section{Ardella exilis (191). Least Bittern.}

Common during summer, this little bird is seldom seen except by those who look for it, and owing to the marshes in which it lives, not always to be found by those who do.

On May 12 ('94, Wholey), six were noted in Patapsco Marsh, but that they are here earlier is shown by nests containing 5, 3 and 1 egrss, respectively, which were noted at the same place on May 17 (93, A. Wolle), and in the last week of Sep)tember, 1894, one was brought to $\mathrm{A}$. Wolle, who kept it alive for some time in his shop window. The latest date for eggs is July \& ('92), when four nearly fresh were collected at Sparrow's Point. It also possibly oceurs more or less regularly on inland swamps. In May, 1S93, one was canght alive in Dulaney's Valley by Mr. Dukehart.

\section{Ardea herodias (194). Great Blue Heron.}

Between March 30 ('93, Gray) and November 19 ('90, Resler) this species is noted with more or less regularity, but so far I have been unable to find a "heronry" in Maryland.

In winter it has been observed at Back River on December 7 and 21 ('92, Resler). Noted at Hagerstown (Small), and Cumberland (Shriver).

\section{Ardea egretta (196). American Egret.}

Irregular during late summer and early fall, this species has been noted from July 5 ('\$2), when one was at Gunpowder Falls a short distance below the Belair Road, to September 1 ('93 A. Wolle), when one was at Guppowder Marsh; on September 23 ('94, Tylor) two were at Ocean City.

In Dulaney's Valley, one out of a flock of 9 was shot by Mr. Thos. Peerse in front of his house, and another was taken by Mr. Dukehart in the fall of 1893.

Possibly sone may nest in Maryland, as "Mr. ITm. Palmer has known this species to nest in Arlington Cemetery, Va." (C. W. Richmond, Auk, v, 19), and "up to 1877 they bred 
near Townsend's Inlet, N. J. (Scott, B. N. O. C., '79), and a few may still breed in the state" (Birds E. Pa. and N. J., 63$)$.

\section{Ardea candidissima (197). Snowy Heron.}

Not as mumerousas its larger relative, it probably visits us about the same time of year. On August 3 ('89, Resler), one of 6 was shot at Middle River, and on August 7 ('so, Resler), another at Back River. ()n August 10 ('sS, Tylor), one at Choptank River, and later in same month another near Greensboro. On August 25 ('93), one near Marlhoro, by Richard Cantler. At Washington it is given as "not uncommon about the marshes of the Potomac towards the end of summer and early fall'" (1. C., 98). In $18 s 6$ they were breeding at Seven Mile Beach, N. J. (H. G. Parker, O. and O., iii, 138).

Ardea tricolor ruficollis (199). Louisiana Heron.

" Warmer portions of Fastern North Inerica; north, casually to New Jersey" (Manual, 131). "Turnbull states that it has occasionally been taken on the New Jersey coast, but we can find no records of recent captures" (Birds E. Pa. and N. J., 64). "I have in my possession a skin of an immature bird taken several years ago at Cobb's Island, and understand fom Captain Crumb that he has heard of '2 othens that have been seen or taken" (Birds Vas., 50).

"6 A printed record (I cannot give reference) says one was preserved in the Maryland Aeademy of Sciences that was shot in Maryland" (Richmond). Mr. Thler has very distinct recollections of the reception of this specimen, but camnot recall particulars ; it occurred in 1868 or ' $^{\prime} 69$.

\section{Ardea cœrulea (200). Little Blue Heron.}

Rare straggler from the south; I know of but one specimen taken near Baltimore, this was shot at Day's Marsh, on Oetober 7, 1892 (Fisher). Others no doubt have been taken and possibly some in the white plumage have been noted under Snowy 
Heron. At Washington, it is given as " rare and only casual towards the end of summer" ( $\mathrm{L}$. (., 99), and "although usually rare, it is sometimes extremely abundant, a flock of alout 150

- frequenting the shores of the Potonac during August 1875" (P. L. Jony, Field and Forest, iii, 51).

\section{Ardea virescens (201). Green Heron.}

Common summer resident, arriving the last of March, a nest ready for egges was found April 15 (')1), and as late as ()etober 12 ('s9, Resler), one was taken at Back River. I have found eggs in the nest from April 22 ('S1), to .June 12 ('94); sets are 4 of 3,13 of 4 , and 8 of 5 . On several occasions, in different parts of the state, I have come acruss "heromies" of this species, the number of nests ranging from 6 to 17, but single nests may be found seattered everywhere, usually near marshy land, or water.

Nycticorax nycticorax nævius (202). Black-crowned Night Heron.

Locally common, otherwise rare, from April 1 (')3, Gray) to Octoher 17 ('94, Resler). Only a f'ew miles from Baltimore city a colony has nested ior several years of which Mr. G. II. Gray, supplied the following: "More than 6 years ago information of the approximate breeding site was received. It wats not until April 16, 1892, however, that it was found, when about 30 nests were in various stages of completeness. They were in slender black oaks, near the top, and about 50 feet from the ground. On April 30 the majority contained eggs. 2 had 5; 3 had 4, 10 or 12 had 3 ; the others 2 or 1 . On June 24 , many of the young were perched about the limbs of the nest trees while others were still on the nests. On March 25, 1593, none harl arrived, but on April 1, seven were seen. On May 6, nests with egges were found in a chump of small serub pines adjoining the oaks, which they had racated. A few diys previous to our visit a severe wind storm had shaken these pines and the 
ground was strewn with broken egg shells. One nest howerer, had 5 eggs and they ranged down to 1 or more; while 2 nests were not yet completed. I measured the height of 11 nests and found they ranged from 36 to 49 feet from the ground. On June 9 they were nearly all back in the oaks occupying the old nests where they had birds just hatehed, the few in the pines containing birds 10 or 12 days old. Among the oals the shells of three eggs were found under 30 nests, the other 6 had 1 or 2 , but poswibly a few egres were not yet hatched. The night of' July 30 was spent in this heronry, but as the moon set early nothing could be seen. Each neit however, secmed to be visited by the parents about once every hour and the noise the young made was something wonderful.

"Owing to changes they did not nest here in 18.94 , but they were found in 1 S.95 located about a mile oft", at the arow Hies, again in black oaks, the nests being from 42 to $4 s^{\prime}$ f'eet up. On May to a few nests showed egres, 4 and 5 being noterl, while on May 11, 3 were noted with 4 fresh, one with 4 nearly fresh; one with 5 nearly hatched, one with 4 young and a rotten egg, one with 3 and another with one fresh egg."

"Wm. Palmer has known this species to nest in Arlington Cemetery" (C. W. Richmiond, Auk, v, 20). "Occasional in winter" (Richmond).

Nycticorax vialaceus (203). Yellow-crowned Night Heron.

A few have been taken in Pemsylvania and New Jersey, where it is regarled as a "very rare straggler from the south" (Birds E. Pa. and N. J., 65).

"Rare summer visitant in the eoast regrion; I have examined a young bird that was taken at Cobb's Island, and think that another bird has been taken there" (Birds Vas., 51).

Order PALUdiCOLAE.-Cranes, Rails, Etc.

Family GruId E-Cranes.

Grus mexicana (206). Sandhill Crane.

"Rare or irregular in the east" (Key, 667). "A specimen of this bird has been procured in the District of Columbia. We 
doubt, however, that the bird has been seen here alive for the past quarter of a century, and it might properly be retired from the active list" (A. C., 100).

Family RALLID E-Rails, Gallinules and Coots.

Rallus elegans (208). King Rail.

Fairly common summer resident of our fresh and brackish marshes. At Patapsco Marsh they have been taken from May 17 ('93) to October 6 ('76, Resler), while on October 13 ('94) I saw a small box of mixed game from Cumberland opened, among others it contained one King Rail.

At Tolchester, on Nay 30 ('91, Fisher), a nest containing 6 fresh eggs was found, and on June 15 ('91, Fisher), another with 10 fresh eggs at the some place.

Possibly some may winter during open seasons; ride-"Two King Sora were lrought to Frederieksburg, Va., on Saturday (Jan. 2S, '93), by Mr. Geo. Newton, of Stafford, and presented to Capt. M. B. Rowe. The appearance of these birds at this season is said to be quite remarkable, as they generally leave on the first appearance of frost" (Va. item in the Sun paper). Stafford is about $6 \mathrm{i}$ miles from the Potomac. In January, 1S95, Mr. Scoggins reccived two King Rail "f rom the Rappahannock."

Rallus longirostris crepitans (211). Clapper Rail.

Possibly resident in sonthern Maryland except when driven out by severe frost; this species, where not persecuted by pot hunters is fairly numerous on salt water marshes during summer. On May 17 ('93), 3 were shot on Patapsco Marsh, one, a female, contained a large number of eggs in the ovary, some quite large, and one in the ovaduct already spotted and ready for extrusion. Noted at Hagerstown in October, '79 (Small).

Rallus virginianus (212). Virginia Rail.

Common during migration, a few remain during summer. On July 8 ('92, Wholey) a specimen was taken at Sandy Point, near 
Ocean City, and at Washington it has been "seen during the breeding season and undoubtedly breeds" (C. W'. Richmond, Auk, v, 20).

Mr. Stone's remarks apply equally well to Maryland, he says: "Summer resident in fresh marher, bogs and swamps along the coast, though apparently not in the true salt marshes except in migrations not very abundant inland, but rather plentiful along the New Jersey coast ; arrives May 1st and remains until Oetober 25, or oceasionally later" (Birds E. Pa. and N. J., 66).

On March 20, '95, in market I saw one with a bunch of Wilson's Snipe; they were perfectly fresh and may have heen shot near Baltimore, but I could not ascertain locality.

\section{Porzana carolina (214). Sora.}

While this species migrates north regularly in spring, it is scldom noted, as the gumers are not then on the rinarshes, but during August, September and Octoler, they are slaughtered by thousands on the marshes of tidewater Maryland.

On August 25 ('94, Fisher) they were abundant on Day's Marsh, they remain so until the first frost; this of course makes their going further south a variahle date. Other dates are few, so they are given in full. On November 18 ('90, Fisher) one was shot in fomerset Comnty. Single birds were taken on December 26 (90) and January 22 (95), at the mud hole back of "Sonny" Barranger's in Canton, lyy Mr. Jas. Holton, and on April 3 ('93) one was shot in a marsh a short distance north of Chincoteague Island, and converquently near the southern Maryland line, by Ir. R. II. I'. Ellis, of Baltimore city.

On July 25, 993, four birds were flushed from a small piece of cattail, by Mr. Geo. Todd, close to his house on North Point. This seems to point to their possible breeding here in limited numbers. It is given as breeding in Chester and Laneaster Countice, Pa. (Birds Pa., 71), and at Washington it has been "seen during the breeding reason and undoubtedly breeds" (C. W. Richmond, Auk, v, 20). Under date of May 25, '95, Mr. 
Richmond says: "I doubt very much now whether it ever breeds here, but it is common in August. Birds have been shot here, one on November S, '78, by Peter' Burger, one on November 9, '78, by S. F. Baird, and one in March, '75.'

Inland, several were shot during the fall of '93, in Dulaney's Valley (Dukehart); at Hagerstown, in October,'79, and September, '80 (Small); at "Cumberland during all of April (not seen after May 1, as shooting stopped then), and from August to October 15, '94" (Zacharia Laney).

\section{Porzana noveboracensis (215). Yellow Rail.}

"Eastern North America, not abundant, very secretive" (Key, 674 ), and as thebird is small it is nowonder it is not of ten seen; possibly it may yet be found to breed with us. On April 27, '93, one was shot on Patapsco Marsh by Richard Cantler, this I saw. On May 18, '89, atHog Creek Marsh, Harford County, one was flushed twice but not secured, by Mr. W. H. Fisher, and on October 20, '94, one was presented to me in the flesh; it was received with a mixed lot of birds, in a box sent from Back River Neck by a market gunner.

"In the collection of the National Museum are two Yellow Rails, both of which were taken on the marshes of the Potomac River near Washington, the first by T. E. Clark, October 4, '79, the second by A. S. Skinner, March 28, 'S4" (II. M. Smith and Wm. Palmer, Auk, v, 147).

\section{Porzana jamaicensis (216). Black Rail.}

"Not often found in the United States, being one of our rarest birds" (Key, p. 674). One secured at Piscataway, Maryland, was presented to the Smithsonian Institute by John Dowell, of Washington, D. C., (Smith. Report,'S4, 145). "One seen in the District of Columbia during September, '61, but not secured. One taken 2 or 3 years ago is now in the Smithsonian" (A. C., 101). Several are recorded from Pennsylvania and New Jersey, (Birds E. Pa. and N. J., 67). 
Ionornis martinica (218). Purple Gallinule.

"South Atlantic and Gulf States, resident, north casually to New England" (Key, 676). Capt. (rumb has one mounted that came ashore on ('obb's Island during a storm in May' ')1, and was captured in the light house yard (Letter to W. H. Fisher). It has also loeen taken in York ('ounty, Pa. (Birds Pa., p. 73$)$.

"One was seen in Centre market (Washington, D. C.) on August 24, 'St by (ieo. Marshall. I visited the market, (Golden's stand) to see about it. The man in charge remembered the 'purple bird,' but thought it had been sold, he said it came from 'down the Potomac somewhere" (Richmond).

Gallinula galeata (219). Florida Gallinule.

Possibly a regular, though rare, migrant. At Stemmer's Rum, Baltimore Co., one was taken on May 8, ('89, Resler). At Wasington, "on April 19, '92, Mr'. Fred Zeller brought me a Florida Gallinule; while the species hats been taken here before, this is the first specimen existing in collections. A f'ew days later, about the $22 d$, ilr. J. D. Figgins secured a specimen from Frederick, Md., and on Mugust 12, '92, Mr. Zeller brought me a young male" (E. M. Hasbrouck, Auk, x, 92).

"Regular transient, but not very common, most of the specimens secured in I'enusylvania and New Jerwey have been taken on the Delaware and Susquehamna River's. Oecurs May 1-10, and September s to ()etober 20" (Birds L. Pa. and N. J., 68).

\section{Fulica americana (221). American Coot.}

Common migrant, noted from March 14 ('93, Fisher), at Gunpowder Marsh, to May 7 (93), when a bunch of 5 were on the broad water of Chester River, and again from September 20 ('79, Resler), at Back River, to November 3 ('91, Resler), at Patapsco Marsh.

A number have been shot at Loch Raven (Dukehart). At Hagerstown, on April 16,' 83 , there was a remarkable flight of 
these birds, hundreds being killed; they were also noted during September and (October, '79, and (October, '81 (Small).

\section{Order LIMICOLA-SHORE BIRDS.}

Family Phalaropodid a-Phalaropes.

Crymophilus fulicarius (222). Red Phalarope.

"A species of eircumpolar distribution during summer" (Key, 614). "South in winter to Middle States" (Manual, 144). "A young bird taken on the Wastern Branch of the Potomac near Washington, D. C., by Mr. F. S. Webster, on October 17, 'S5, is now in the National Museum" (Smith. Report, '87, 603).

Phalaropus lobatus (223). Northern Phalarope.

Cirempolar, like the last species, but coming much further south in winter. Under date of May 2S, '95, Mr. C. W. Richmond writes me from Washington, "one was taken here in September, '91, by Mr. Thomas Marron off Navy Yard bridge; the specimen is now in the National Museum."

\section{Family ReCurvirostrid E-Stilts.}

\section{Himantopus mexicanus (226). Black-necked Stilt.}

Uneommon on the Atlantic coast from Florida to Maine; now rare, it may yet oceur on the ocean front of Maryland. "Formerly it bred regularly in Cape May County, N. J., and on Egg Island, Delaware Bay (Turnbull, '69). We know of no recent captures of this species" (Birds E. Pa. and N. J., 70).

\section{Family Scolopacid 2 -Snipes, Sandpipers, etc.}

Scolopax rusticola (227). European Woodcock.

Straggling from Europe, this species has been taken quite close to Maryland, but as far as I know not within the state. "In the early part of November, '86, Mr. D. N. McFarland, 
of West Chester, Par, killed a large female in the 'barrens' of East Nottingham Townsip, Chester County, Pa." (Birds Pa., 78), and Dr. Cones reports one being shot in Ioudoun ('ounty, Va., in '73 (Forest and Stream, vi, 180).

\section{Philohela minor (228). American Woodcock.}

Resident, except when f'rozen out, and fairly common in spite of the .June and July gunners who slaughter many birds before they are much more than half grown, and leave other's still younger parentless.

Nesting dater range from March 30 ('S()), when four slightly incubated eggs were fouml hy Mr. IV. I. Amoss near Fallstown, IIarford County, to . July 4 ('):3), when a nest, also with four eggs, was found (all sets I know of are four).

At Cumberland, where they are not found in winter, the first was shot on March 28, some years ago, and the last on December 12,'94 (Zacharia Laney).

\section{Gallinago delicata (230). Wilson's Snipe.}

Common during migrations. On February 24, 95, I fushed one from a warm spring in Dulaney's Valley, and on March ? (95, Henninghonse) they were numerous at Gunpowder Marsh, where they were still numerous on April 22 ('2.2, Pleasants), the last spring date being Ipril 29 ('94), in Dulaney's Valley, thongh at Vashington they are noted until May 5 (Richmond).

In the fall I have them noted from September 20 (93), at Patapseo Marsh, to December 11 ('14), Bush River. There is every possibility that more or less remain with us during mild winters.

The following note on this species breeding in Maryland is taken from Lewis' American sportsman, (18S5 edition, p. 244). "In the month of May, 1846, while wandering in company with Mr. E. Lewis over his extensive estate in Miryland, we sprang a Wikon's Snipe from the midst of an oat field, and being surprised as well as attracted by its singular manouvres, 
we made search for its nest which we soon found with four eggs in it. The situation selected for incubation could not have been better chosen in any portion of the country, as it was on a rising piece of ground, with a southern exposure, protected in the rear by a large wood, and at the foot of the high ground was a considerable extent of low marsh meadow watered by a never-failing stream, along the border of which the anxions parent at any time could obtain a bountiful supply of food."

Mr. Zacharia I aney, of Cumberland, informs me that he has taken this species from February 28 to the last of the gunning season, April 30; how much later they stay he does not lnow, but some years ago while exereising a pair of young dogs in June, they flushed a pair from a marshy slew.

Macrorhamphus griseus (231). Dowitcher.

Common during migration in tidewater Maryland during April and May, and from early in August to the first touch of cold weather; a specimen in the collection of Mr. A Resler was taken at Back River as early as March 6 ('75). Inland, Mr. Dukehart has secured a number in both spring and fall in Dulaney's Valley.

\section{Macrorhamphus scolopaceus (232). Loug-billed}

Dowitcher.

Of this western species "seven were killed from a Hock on the Anacostia River, D. C., in April, 1884, by a gumner who sold them in the market for Jack Snipe. One similar to the others was secured and mounted by one of the writers and has been identified by Mr. Ridgway as the western species" (Hugh M. Smith and Wm. Palmer, Auk, v, 147).

\section{Micropalama himantopus (233). Stilt Sandpiper.}

Casual migrant on the Atlantic coast, one was " taken on the Patuxent River, Md., September S,'85, by Mr. H. IV. Henshaw. This capture was made beyond the regular District of Columbia 
boundary, but was, however, included in what has leeen tacitly regarded as its faumal and floral limit" (Hugh M. Sinith, Auk, iii, 139).

\section{Tringa canutus (234). Knot.}

Common migrant, given on the New Jersey coast f'rom May 15 to June 1, and from August 15 to September 15 (Birds E. Pa. and N. J., 73). On Cobb's Island 19 were shot on May 20 (' 11 , Fisher), and from May 11 to 28 ('04), they were "quite numerous occuring in large fiocks. On May 25 hundreds of these birds were seen feeding along the extensive numd flats on the outer sea beach" (E. J. Brown, Auk, xi, 259).

On August 19, '93, quite a number were shot a f'ew miles south of Ocean City on the beach (Janon Fisher).

\section{Tringa maculata (239). Pectoral Saudpiper.}

"Inited States chiefly during migrations, when oloserved in wet grassy mealows, muldy pondi, flat s, ete." (Key, 1526). "Rare in spring, not unemmon from September 25 to Tovember" (A. C., 96.)

Near Washington, "on April 22,'88, two were shot by W. F. Roberts; several were taken on August 3 (about '89); at St. George's Island, Mil, several were seen on September :3 and 11, '94; and one was shot October 22,'60" (Richmond).

"Regular migrant on the New Jersey coast in April, and from the middle of August to the first of (Oetober; oceasional in the interior" (Birds E. Pa. and N. J., 73).

Tringa fuscicollis (240). White-rumped Sandpiper.

"Transient on the New Jersey coast, but not very common, associating with the Least Sandpiper, and arriving and departing with it" (Birds E. Pa. and N. J., 73).

"E. J. Brown has two or three skins taken in May, between the 15th and 24th, '14, at Smith's Island, V'a," (Richmond). 
Tringa bairdii (241). Baird's Sandpiper.

Migrant, "rare on the Atlantic coast, common in the interior" (Key, 626). "One was shot by R.S. Matthews, near Four Mile Run, Va., on September 3, '94, and Wm. Palmer shot a second specimen on September 25, '94, at the same place" (Richmond).

\section{Tringa minutilla (242). Least Sandpiper.}

Common migrant all through May, and again from August 2 ('92), [in New Jersey, Stone says July 15] to November 3 ('94), when four were shot at Back River. Numerous along the shores of tidewater Maryland, bunches of "Peeps" may be found along all our rivers, streams, rums, ice ponds, etc., whereever there is wet mud.

Tringa alpina pacifica (243a). Red-backed Sandpiper.

Common during migrations in tidewater Maryland; this species has also been noted on our larger inland waters; possibly some remain during mild winters in southern Maryland. On September 3 ('93), one was at Loch Raven, and on the 17th, two. On March 13 ('92, Wholey) four were at Waverley, while on May 24 ('93), I shot two out of a bunch of four on Hail Point, Kent County, at the mouth of Chester River.

Ereunetes pusillus (246). Semipalmated Sandpiper.

Common during migrations, but not as mumerous as T. minutilla, with flocks of which it is generally found, arriving and departing at the same time.

Near Washington, D. C., recorded from August 13 ('94) to October 26 ('87), and again in May (Richmond).

Ereunetes occidentalis (247). Western Sandpiper.

"During the last week of August, 1885, I found the western bird quite as common as the eastern at Piney Point, St. Mary's County, Md., on the P'otomac River. If anything, the former was the most numerous, for, of the 18 specimens of 
Eicunctes preserved, 14 were identified by Mr. Ridgway as occidentales, and these too were taken at random from a lot of about 25 dead birds" (Hugh M. Snith, Auk, xi, 385). Several were shot at Virginia Beach, on Geptember (; and 7, 1884 , hy Messrs. Henry Seebohm and C. W. Beckham (Auk, xi, 101). Two have been taken in New Jersey: one on September 14, 's0, the other on May 17, '92 (Birds E. Pa. and N. J., 75).

\section{Calidris arenaria (248). Sanderling.}

Abundant coastwise during migrations; several were seen and one shot at Cobb's Lsiand on May ?0 (') 1, Fisher), and one was taken at Ocean City on September 23 ('94, Tylor).

"Near Washington one wats taken on Feptemher 23, 'at, by Wm. Palmer; another in '74, and one on Oetober 24, 'S5, at Gravelly Run" (Richmond).

"Abundant transient on the New Jersey coast, keeping pretty much to the beach, April 18 to. June 1, September 14 to Oetober 15. Some also are said to remain through the winter. Dr. W. L. Abbott secured one specimen in the spring migration as late as June 13. Occasional on the lower Delaware" (Birds E. Pa. and N. .J., 75).

\section{Limosa fedoa (249). Marbled Godwit.}

This species "dloes not appear to go far along the Atlantic coast northwarl" (Key, 635). Rather rare transient on the New .Jersey coast, where it seems to have been more plentiful formerly; oceurs in May, and again from the last week of July to September 15. Dr. Warren states that a few have been captured in recent years in Lancaster, Philadelphia and Delaware Counties" (Birds E. Pa. and N. J., 75).

\section{Limosa hæmastica (251). Hudsonian Godwit.}

"Much less abundant in the United States than the preceding, and appears to range chiefly along the Atlantic coant" (Birds $N$. W., 494). "On May 16,'S6, I shot a Hudsonian Gudwit at 
West River, Mcl., in a grass field adjoining the village of Halesville" (J. Murray Ellzey, Forrest and Stream, xxvii., 264).

Totanus melanoleucus (25t). Greater Yellow-legs.

Common migrant, but not so numerous as the following species. On March 26 ('75, Resler) one was taken at Patapico Marsh, and on June 7 ('94) one at Ocean City. In fall, Mr. Stone gives them as early as July 15 in New Jersey (Birds E. Pa. and N. J.), and $\mathrm{Mr}$. Richmond at Washington from July 25, but my earliest note is a flock of 35 in Dulaney's Valley on August 12 ('94), while as late as November 4 ('93), I received one from Patapseo Neck (probably shot about the 2nd or 3rd), and another from Cumberland, also probably shot at the same time.

\section{Totanus flavipes (255). Yellow-legs.}

More numerous than the former, in the spring from March 15 ('95), at Havre de Grace, to May 17 ('93, Wholey), at Patapsco Marsh, and again from August 12 ('94), at Loch Raven, to September 5 ('93, J. H. Fisher, Jr.), at Spring Gardens. At Washington, September 11 (94, Wm. Palmer and R. S. Matthews).

Totanus solitarius (256). Solitary Sandpiper.

A regular but not abundant migrant, generally found singly or in pairs in spring, and in small flocks in fall. Noted from April 25 to May 30 ('91, Gray), and from August 13 ('93, Gray) to October 12 ('89, Resler).

This species is a rare summer resident, though its nest has not yet been recorded in Maryland. On July 14, '93, one was in company with a Fildeer in the hed of Gwynn's Falls, at Calverton (Gray and Blogg).

"Occasionally one is scen during the breeding season" at Sandy Springs (Stabler). "In Maryland and Virginia. . . . I have shot birds in August so young as to leave no doubt in my mind that they were bred in the vicinity" (Birds N. IV., 499). 
At Washington, D. C., it is recorded as follows: "April 26 ('91) one scen, May 16; ('SS) one seen, July 20 ('90) one noted, July 28 ('S9), two seen, August S (94, Wm. Palmer) one seen, August 11 ('S9) one seen, and on August 21 ('94 E. J. Brown), several seen and shot" (Richmond).

"Dr. Treichler, of Lancaster County (Par.), mentions it as an irregular brester; he has found rommg ahout half grown in the Conowingo meadows early in July" (Birds Pa., 91).

On May 23, '93, I came across one feeding in an ice pond with but little water; I was within 20 feet and watched it through a field gliss. It walded with a dainty step, sometimes having perceptibly to pull its fert out of the mud, and once when it got in deeper water swam a few feet with a hurried stroke. Small insects on or in the water, on bottom, on weed stems or on bank it swallowed at once. Tiny tadpoles it worked a second between mandihkes and dipped a couple of times in water, apparently to get them head first. One large one it immediately ran ashore with and hammered it on the ground for some little time before swallowing it. In wathe it sometimes had the water up to its breast and belly. Generally not more than the bill was immersed, lut of ten the heal, oceasionally the neek, and once half of the body.

\section{Symphemia semipalmata (258). Willet.}

While not as numerous as it used to be, this species is not uncommon on our ocean front, where it still breed in limited numbers. At Chincoteague Bay y I noted one on June 5 ('94); another on the next diay, and three on the 7 th at the same place ; and Mr. C. Wr. Dirickon, of Berlin, says: "On their way north in spring a few stop and stay with us all summer. They lay their eggs in very much the same place as the terns, and in fact you can sometimes find both nesting very close together." I am informed that they breed in large numbers on Chincoteague Island, and also on Mockhorn and Smith's Islands, Va. "A few still breed on the New Jersey coast" (Birds E. Pa. and N. J., 76-77). 
On August 19 ('93, Janon Fisher) a number were shot a few miles down the beach from Ocean City. On August 27, '93, a bunch of about 30 were on the flats opposite the Navy Yard, Washington, D. C. (B. A. Bean, Forest and Stream, xli, 230). On November 3, '94, I saw a single bird in the Baltimore market, still quite fresh, which had been shot "down the necks," possibly one or two days before.

\section{Pavoncella pugnax (260). Ruff.}

On September 3, '94, a bird of this species was shot at Four Mile Run by Wm. Palmer (Richmond). This European species has occasionally been taken on the coast of New England and the Middle States (for references see Key, 641).

\section{Bartramia longicauda (261). Bartramian Sandpiper.}

Common during migrations and fairly represented in summer. In Dulaney's Valley they were first noted on April 21 ('94, Fisher), the migratory birds leaving about the middle of May; they are noted again from August 11 ('95) to September 8 (95). This year ('95) two pair spent the summer in the north end of the valley, and about a mile apart. These I visited weekly; up to July 14 both birds of each pair would allow of quite close approach, one, presumably the female, of ten circling round within 50 feet. They gave every sign of nesting, but it was not until early in August that the young were seen flying with the parents. On August $S$ two young birds were shot. These birds were flying in two bunches of 4 and 6 until September 1.

On July 3 ('95) one, evidently lost, was flying round calling over an electric light in Baltimore City at $11.30 \mathrm{P}$. M.

"On July 27 ('89) one was shot at Laurel by Geo. Marshall. First recorded at Washington on April 6 ('92); few stop on their passage, but they are commonly heard while migrating at night" (Richmond). "A summer resident, rare at that season" (A. C., 83). 
Actitis macularia (263). Spotted Sandpiper.

Common summer resident from April 8 ('93, Gray) to Oet. 18 (94). Numerous all through the state wherever there is water; they regularly spend the summer at Druid Hill Lake, and a few years ago I frequently observed a pair on Jones Falls opposite Union Station, where no doubt they had a nest.

On May 30 ('91, J. H. Fisher, Jr.), a nest was found at Tolchester, containing fon nearly hatched exgs, and on July 21 ('95), four young were still being led by the parents.

On July 21 ('95), I watched one for some time; the speed with which it ran after a fly, with sucheu doubles, was remarkable; every once in a while it stopped to seratch the back of its head, finally it thought a wash would do that head good, so flying to a shallow part of the run, it syuatted down in the water and hegan to duck its head under, scratehing the back of its head on both sides with the mail of the long middle toe, until it got every feather raised and quite wet. The balance of the body received no attention. Hopping on a stone it dried its head by rubbing it against its sides several times and then flew away. This head washing lasted nine minutes.

Numenius longirostris (26t). Long-billed Curlew.

Breeding on the Atlantic const as firr north as North Carolina, and casually north to New England, this species is "a straggler on the New Jersey coast, occurring generally in May and September" (Birds E. Pa. and N. J., 7S). (On May 23 ('93), two were on Hail Point, Kent County. On August 19 ('93, Janon Fisher), quite a number were shot a few miles south of Ocean (ity, and during September ('\$?, G. A. Rasch), they were unusually plentiful at Cobb's Island.

Numenius hudsonicus (265). Hudsonian Curlew.

Migratory through the United States. One day in August, 1851, W. H. Fisher shot three about eight miles below Ocean City, Md. On May 19 ('91), he saw a good many at New 
Marsh, Cobb's Islaud, but they would not decoy, and two days later he saw quite a number at Smith's Island. Given as "common transient along the New Jersey coast, oceurring May 1 to June 1, and July 15 to September 15" (Birds E. Pa. and N. J., 78). On May 10 ('95), five and one Curlew flew over Baltimore (ity, presumally they were of this species.

Numenius borealis (266). Eskimo Curlew.

Migrating through United States. Captain Crumb calls this species a rare and irregular migrant at Cobb's Island (Birds Vas., 57). "Rare transient on the coast, appearing in May and again in September, according to Turubull" (Birds E. Pa. and N. J., 78).

Family Charadridde-Plovers.

Charadrius squatarola (270). Black-belled Plover.

"Migratory in United States, preferably coastwise, common, but less so than dominicus" (Key, 59S). Three were noted at Waverly on May 12 ('94, Wholey), and one in Dulaney's Valley the next day. On May 19 ('91, Fisher) three were shot at Cobb's Island, Va., and next day two more from numerous flocks observed. Given as common on the New Jersey coast from April 30 to May 22, and from latter part of July to September 15 . Dr. W. L. Abbott has taken specimens on June 3 and November 7 (Birds E. Pa. and N. J., 7S-79).

Charadrius dominicus (272). American Golden Plover.

In New Jersey "very erratic transient, rarely seen in spring, but at irregular intervals oceurring in large flocks in the fall" (Birds E. Pa. and N. J., 79). At Washington, "rare and irregular migrant" (Richmond); at Cumberland (Shriver). 


\section{AEgialitis vocifera (273). Killdeer.}

Common in summer all over the state; this species is very numerous during migrations in ticlewater Naryland, where during mild winters more or less may winter. In Dulaney's Valley this species is a common bird from Narch 10 ('95) to December 22 (').4), while at Powhatan Dim it was noted as early as February 25 ('93, Gray). The set of eggs is, as far as I know, four. Fresh egg's were noted May 28 ('92), one hatched and three pipped, on June 5 ('91), and young still with the parents on July 23 ('93).

On and after July 14 ('95), they are usually to be found in flocks, 53 on one oceasion being counted in a close bunch.

Egialitis semipalmata (274). Semipalmated Plover.

Common migrant appearing on ocean front, sand beaches of Chesapeake Bay and mud flats of our larger inland waters from early in May to the 29 ('SO, Resler), when one was taken at Patapsco Marsh. Returning late in July, and remaining until September 22 (94, Tylor), when five were taken at Ocean City. On August 12 ('94) and 29 ('93, Fisher), they were numerous along Loch Raven.

\section{Ægialitis meloda (277). Piping Plover.}

On June 5 ('94), one feeding in the wash of the waves a few miles from Ocean (ity was noted and three days later, one back where the sand and marsh grass meet, gave unmistakable evidence of having either eggs or small young, but neither could be found.

Given from April 15 to May 15, and in September and October as a transient, a few breeding, and also wintering on the New Jersey coast (Birls E. Pa. and N. J., 79-S0). Capt. Crumb states that it has nested at Cobb's Island. 


\section{Agialitis meloda circumcincta $(277 a)$. Belted Piping Plover.}

This western species is occasional on the Atlantic coast. On May 3, 's4, a specimen, now in the National Museum, was obtained on the shore of the Potomac opposite Washington, near the Long Bridge (H. M. Smith and Wm. Palmer, Auk, v, 147).

\section{Agialitis wilsonia (280). Wilson's Plover.}

Common during summer along the Atlantic coast as far north as Virginia. At Cobb's Island, Va., Mr. H. B. Bailey found it a comparatively common bird, May 25-29, '75 (Auk, i, 26), and they were found breeding there on May 20,'91 (Fisher). "Rare straggler on the New Jersey coast, where it probably bred a few years ago" (Birds E. Pa. and N. J., S0).

Family APHRIZIDE-Turnstones.

Arenaria interpres (283). Turnstone.

Common migrant on our ocean front during Nay, August and September. Apparently irregular on the Chesapeake, they have been taken as far up the Potomac as Washington, D. C. "Three Turnstones in the National Museum were taken in the District of Columbia hy Mr. C. Drexler in 1860 (?). In June, 's2, Mr. J. A. Moore killed a bird at Jones Point, Va., near Washington. In May, 'S1, Mr. O. N. Bryan secured one, and saw another at Marshall Hall, Mad, and we know of the occurrence of three others on the Potomac River within the past three ycars" (H. M. Smith and Wm. Palmer, Auk, v, 147-148).

Family HжмAтороDID ж-Oystercatchers.

Hæmatopus palliatus (286). American Oystercatcher.

Common on the coast of the Southern States during summer. At Cobb's Island they were found breeding, and eggs were taken during June, ' $8 S$ (Theo. W. Richards, Oologist, vii, 186), 
and on May 20, '91, several pairs were observed there (Fisher). On Jume 5, '91, one was noted flying south at North Beach, a few miles south of Ocean City, Md. "Very rare straggler on New Jersey coast" (Birds E. Pa. and N. J., 81).

\section{Order GALLIN E-Galdinaceous Birds.}

Family Tetraonide-Grouse, Bob-whites, ete.

Colinus virginianus (289). Bob-white.

Common, resident; May 2 ('93) is the earliest date I have heard the well-known call of "Bob-white," this is generally stopped by the early part of September ; it has, however, been heard as late as October 23 ('88, Wholey). Their equally wellknown whistle and the faint "click-click" of the covey may be heard at any time. Usually the call is given from the top of the fence, but I have heard it repeatedly given by birds in trees. The nest is seldom found except during harvest when numbers are uncovered. Sets are one each of $8,12,14,18$ and 22, and 2 of 10 . A nest with eggs was found as late as September 1 ('95). A covey of 7 or $\$$ holding together rather late was flushed near Magnolia on May 4 ('9:', Fisher).

\section{Coturnix communis-European Quail.}

In the fall of '79, Messi's. Poultney, Trimble \& Co. imported about 200 birds from Italy. These Mr. Charles D. Fisher turned loose on his place at Ruxton, but never saw anything of them afterwards. The following spring about 1000 were imported, and $\mathrm{Mr}$. Kleibacker tells me there were several eggs in the boxes when they arrived. Quite a number were turned out on the "Dundee Shore," where occasionally one or two were seen during the summer, but early in fall they entirely disappeared. Messrs. Charles B. Rogers and Geo. Brown also liberated a number in Green Spring Valley, where at least one pair nested. Mr. Rogers writing me under date of January 27 , '93, says : “There were several pairs of the birds on our property. I remember that a nest was found near our blacksmith shop, it was on the ground in a cluster of weeds, and if I remember correctly had 13 eggs in it. Nothing however was ever seen or heard of the Quail after the first winter." Mr. Isaac Slingluff writing in reference to the 
above, says : "The nest was found close to the bank of Shoemaker's Run. I think there were 12 or 13 eggs in it, 4 of which did not hatch." One of these is now in the possession of Mr. Jesse Slingluff.

Mr. I. W. Hasbrouck, of Washington, writes me, "In February, '95, I saw a bunch of European Quail exposed for sale on the street; they were said to have been killed near Opequan Creek, but I could get no further information."

\section{Bonasa umbellus (300). Ruffed Grouse.}

Common, resident. On May 2 ('94, Fisher), a nest with 10 fresh eggs was found. During July a covey of young, about as large as partridge, were seen near Ellicott City by Mr. Basil Sollers, and on June 10, '95, at Vale Summit, I came across a pair with 8 or 10 young about the same size.

\section{Tympanuchus americanus (305). Prairie Hen.}

Early in the winter of ' 85 or ' 86, Col. Edw. Wilkins got 12 or 15 birds from the west and kept them until spring when he turned them loose in his orchard, on the Chester River, about four miles below Chestertown, Kent County; a few days later two or three were seen and then they disappeared. On Easteru Neck Island, Mr. Spencer Wicks shot one in the fall, and Mr. Newton Bogle several times saw another dusting itself in the road in the front of his house. Possibly these were some of Col, Willins birds. "Mr. Ridgway records the killing of a Prairie Hen on the Virginia side of the Fotomac, near Washington, March 17, '85 (Forest and Stream, xxiv, 204 and 248). It has been suggested that it was a descendant of birds, liberated previously at Snow Hill, Maryland" (Birds Vas., 59).

Family Phasianide-Pheasants, etc.

Phasianus colchicus. European Pheasant.

Col. W. F. Mason MeCarty tells me that some years ago a number were liberated on the grounds of the Woodmount Gunning Club in Washington County. They are now fairly numorous, and this colony may be considered as established. Occasionally birds wander off, and have been shot quite a distance away from the preserve.

\section{Meleagris gallopavo (310). Wild Turkey.}

Mr. Robert Shriver writing from Cumberland, says, "Indigenous here, about as abundant as ever, they seen to be less 
numerous some seasoms, owing probably to severity of weather or excessive hunting."

Mr. Wm. H. Fisher supplies the following: "Mr. J. R. Ridgley tells me that on his farm in Howard County, about 10) miles from Ellicott City, some years ago he was listening for squirrels and became conscious of a wild turkey, when too late to secure it." He also says "that now ('93) there are a few near his farm in a tract called Beaver Dam Woods."

Mr. Harden, of Georgetown, shot two in the winter of ' $81-82$, between Georgetown and Tennallytown (A. C., '92).

"While at Wererton on September 26, '93, John Lcopold told me that about the first of the month a flock of at least 10 were seen, and that now a flock of seren young, with two adults, is on the other (Virginia) side of the river. Occasionally he has seen turkeys fly arross the river, and once one gave out and fell into the water" (Fisher).

\section{Order COLUMBA-Pigeons AND Doves.}

Family Columidide-Pigeons and Doves.

Ectopistes migratorius (315). Passenger Pigeon.

Originally ocenring in large numbers, but only occasionally seen of late years. On August 27, '93, I flushed a pair from a fence in the upper end of Dulaney's Talley and further down a single bird from a tree top. These birds I watched for some time through a field glass, but none of their actions differed from those of doves. Mr. Wm. H. Fisher supplies the following: "For alpout 10 dars, in ()etolser' TS, flocks of Wild Pigeons flew over our house at Mount Washington between 7 and 7.30 A. M.; 6 to 10 flocks of from 5 to 20 birds each day. In September, 'ss, I shot one near Bradshaw, and in Septenher, 'S!), another in Dulaney's Valley; this last was flying with a flock of Doves. Mr. .J. R. Rirlgley tells me that he saw a flock of 50 or 60 about 8 miles from Ellicott City on September 17,'93. Clarence Cottman salys he saw a flock of about 10 pass near the 
head of Lake Roland and fly up Green Spring Valley on September 19, '93."

Dr. Coues, speaking of the District of Columbia, says: "I once killed a specimen so newly from the nest as to cause me to believe that it had been hatched in the vicinity" (Birds N. W., 389).

They were once very common at Cumberland, but of late years have become very rare (Shriver). At Vale Summit I was told that the last flight occurred there on the evening of New Years day '77, when the sky was black with them and large numbers were killed.

\section{Zenaidura macroura (316). Mourning Dove.}

Common, resident. The usual set of $2 \mathrm{eggs}$ is recorded from April 1 ('82, Small), at Hagerstown, to August 17 ('93, Stabler) at Sandy Springs; near Baltimore, from April 9 ('93) to August 13 ('90, Resler). The nest is usually placed on a fork, or among twigs on a horizontal branch, where it is flat and shallow, but I found one built in the fork of a split cedar 14 inches from bottom to top. I have also found a number in old nests (Robin, Purple Grackle, (ardinal, etc.), also on fence rails and one on top of a stump. Dr. Warren cites several on the ground (Birds Pa., 114).

During fall they unite into bunches and flocks, these are recorded from August 3 ('95) to $\Lambda_{\text {pril }} 3$ ('93); as a rule they do not range above 25 , but I have seen about 50 , and $\mathrm{Mr}$. Wm. H. Fisher saw one of at least 200 on August 26, '93.

Columbigallina passerina terrestris (320). Ground Dove.

Common in the Southern States; "its usual range is limited by the Carolinas, but I have a record of the capture of a specimen many years ago at Washington" (A. C., 91. Birds N. W., 390). Another specimen shot by Mr. Thos. Marron on Oct. 14, '8S, at Broad Creek, MId., is now in the National MIsseum (Smith. Report, '89, 117, 358 and 801).

One was taken in Lancaster County, P'r., in '4t (Birds E. Pa. and N. J., 80). 


\section{Order RAPTORES-Birds of Prey.}

\section{Family Cathartide-American Vultures.}

Cathartes aura (325). Turkey Vulture.

Resident, common. 14 sets of 2 eggs are recorded from April 19 ('82, W. L. Amoss, Fallston) to May 30 ('91, Stabler, Sandy Springs). I have several times heard of 3 eggs, but never could verify the statement. The eggs, nest there is none, are placed in hollow prostrate logs, hollow stumps, under rocks, stones, or bushes, and in one case under the worn side of an old straw stack. Given as resident at Hagerstown (Small), but only as casual at C'umberland (Shriver); at Vale Summit I only saw 3 in 10 days (June 5 to 14, '95).

While usually not noticed by other birds, I saw a crow chase one on May 8,'92, and a Fish Hawk chase another on May 30, '93.

\section{Catharista atrata (326). Black Vulture.}

"North, regularly to North Carolina, irregularly or casually to Maine, New York, ete." (Manual, 222). "Rarely breeds North of $367^{\circ}$ " (Bendire, 16.5). "On March 30, '95, at Kensington, Md., Mr. J. D. Figgins saw 4 birds which he supposed were of this species. He had never seen the Black Vulture in life, but was familiar with the other large birds known to occur here and from his description of the actions of the birds, I have no doubt they were really of this species" (Richmond).

Family Falconid E-Falcons, Hawks, Eagles, ete.

Elanoides forficatus (327). Swallow-tailed Kite.

"On the Atlantic coast its natural limits appear to be the lower portions of Tirgina, but it has more than once occurred in the Midulle States" (Birds N. W., 332). On April 5, '(13, I examined a mounted specinen; on inquiry I was told it had been shot by Mr. W. T. Levering, Jr., on Maidens Choice Lane, close to Kenwood Station, near Catonsville, Baltimore County, late in the summer (late July or' early August) of ' 89. 
While in Queen Anne County (May '92) my boatman several times mentioned a "white Hawk with a split tail" which he had observed occasionally, but he could not tell how often or at what time of year. Mr. A. P. Bowen writes me that it is occasionally seen in Prince George's County.

\section{Circus hudsonius (331). Marsh Hawk.}

Common resident in tide-water Maryland, this species is common in the uplands from August 4 ('95) to May 2 ('91, Gray), and on June 29 ('92, Gray) one was seen near Powhatan. Mr. L. D. Willis, of Church Creek, Dorchester County, informs me that on a salt marsh of the Blackwater River, about 10 miles south of Cambridge, he found a nest of the Marsh Hawk containing 6 fresh eggs on June 2, '95. Next day the female was shot and an egg ready for extension was found in the ovaduct. The nest, a slight affair of dry reeds and grass, was placed on a slight elevation about 60 yards back from the open water and entirely surrounded by thick reeds.

\section{Accipiter velox (332). Sharp-shinned Hawk.}

Common resident, but not very numerous in summer. On May 20 (91, Blogg) a set of 4 eggs was taken, and on May 29 ('92, Fisher) another of 5 . At Sandy Springs on May 16,'91, two fresh eggs, and 15 days later a set of 5 (Stabler).

For two years in succession this terror of the poultry yard nested close to our house, but as far as I could learn the chickens were not molested. In ' $S t$ the young had left the nest and were being fed round the house on June 8, 15 and 22. In 'S5 I spent May 31 and June 7 watching the young being fed. They were in a natural cavity of a chestnut tree in full view of the house and not 100 feet away from it. The entrance was a small rotted-out branch hole about 4 inches in diameter and about 40 feet from the ground. By meaus of a field glass I saw that the young were being fed on grasshoppers. On the approach of a parent they made a great noise, and as this could 
easily he heard all over the house, the feeding was continuous from "the dawn's early light," until it was too dark to see the birds come and go. The nest of this species is usually placed in the twigs of a cedar or pine.

\section{Accipiter cooperi (333). Cooper's Hawk.}

Resident, but at all times less numerous than velox. The nest is built early in April, and the birks stay around it a long time before the eggs are laid. On April 29 ('91, Stabler') a set of eggs was taken at Sandy. Springs, and on June 20 ('SS, Resler), two birds, at most a week old, were in a nest in Howard County. Sets are 1 of 2,2 of 3 and 2 of 5 .

\section{Accipiter atricapillus (334). American Goshawk.}

Maryland appears to be the southern limit of this species in winter, but it is not taken here often. In '68, Dr. J. Lee MeComas, of Cumberland, sent two, shot in Maryland, to the Snithsonian (Smith. Report, '6S, 57), and another sent to Dr. A. K. Fisher, was taken in a steel trap by Mr. Leizear, of Sandy Springs, on December 27 ('87, Stabler).

\section{Buteo borealis (337). Red-tailed Hawk.}

Resident, common, but not of ten seen in summer. Two slightly incubated eggs were taken on March 25 ('94, Hoen), and three birds just hatched were seen on May 7 (93), while two birds apparently just out of the nest were trying to follow their parents on July 5 ('94). Sets are 1 of $1 ; 5$ of $2 ; 2$ of 3 and 1 of 4 . Outside the breeding season they are more or less gregarious, at times being seen in quite large flocks.

Buteo lineatus (399). Red-shouldered Hark.

Inside the limits of Baltimore City this is the most numerous hawk at any time of the year, but in Baltimore County borcalis far outnumbers it. On March 20 (93) two sets of fresh eggs: 
were taken (a ring of snow was round each nest, and it was two feet deep on the ground); while on May 6 ('94, Wholey) a set nearly incubated was collected, and on May 31 ('91) a second set was taken. Sets are 5 of $2 ; 4$ of 3 , and 4 of 4 .

Outside the breeding season, this species, like borcalis may sometimes be seen in flocks, more of ten in bunches of 3 or 4 to 10 , but generally singly or in pairs.

\section{Buteo latissimus (343). Broad-winged Hawl.}

Resident, but not common. On April 27 ('91) a set of three eggs was taken; on May 19 ('92, Blogg) a set of two, and on May 23 ('92, J. H. Fisher, Jr.) a set of three nearly incubated. At Sandy Springs, a set of three was taken April 9 ('91); one of three in May ('92); one of two on May 15 ('92), and another of two on May 22 ('92, Stabler).

The three Butcos are the hawks usually shot by our farmers, because they are large, fly slow, and are called "hen-hawks," while the much smaller, swift flying, Falcos and Accipiters, that may at times take chickens, escape.

Archibuteo lagopus sancti-johannis (347a). American Rough-legged Hawk.

"Along the Delaware, below Philadelphia, it is still found in considerable numbers from November to the end of March" (Birds E. Pa. and N. J., 87). It does not appear to be numerous in Maryland. On January 24, '92, in Dulaney's Valley, one sitting on a tree allowed me to drive slowly past within twenty feet of it. Dr. M. G. Ellzey sars this species was very numerous in Howard County during the winter and spring of '87-8S (Forest and Stream, xxxii, 212). At Sandy Springs one was shot by Mr. Leizear on March 17, '88 (Stabler). One was seen on the Virginia side of the Potomae, opposite Washington, on December 29, '79, by Mr. H. W. Henshaw (A. C., 88-9), and it has been taken in the District of Columbia (L. M. McCormick, Auk, i, 397). 


\section{Aquila chrysaëtos (349). Golden Eagle.}

An irregular winter visitant. On June 30, 'S3, a mounted specimen was presented to the Maryland Academy of Sciences, by Dr. Murdoch; it was shot at Back River, and had five toes instead of four. On November 28, '94, one was shot at Otter' Creek, Harford County; this specimen I had mounted. Four were secured in Maryland, near Washington (see Smith. Reports, '62, 58; '69, 55; '75, 73; '91, 793). On December 8, '87, one was shot at Gaithersburg (Fisher's Hawks and Owls, 97). One in the First National Bank of Cumberland was shot by Mr. Robert Shriver about 30 years ago. "Until about 1856 , for many years a pair is said to have nested in the southern part of Lancaster County on a lofty jutting eliff' over the Susquehanna River" (M. W. Raub, Auk, ix, 200).

\section{Haliæetus leucocephalus (352). Bald Eagle.}

Resident, and generally dispersed along the shores of the Chesapeake Bay and other larger waters of Maryland, being fairly common. At Loch Raven it is no musual sight to see one or more, and Dr. Wilson, of Gleuarm, tells me that about 40 years ago there was a nest used year after year with half a mile of his house. I have only found the nest "down the necks" and on the Eastern Shore; but they breed all along the Potomac as far up ar Hancock. On March S (9t) three eggs nearly fresh were taken; on March 27 ('95), two nearly fresh; on March 29 ('93), two about two-thirds incubated; on April 15 ('93), two lirds, five or six weeks old, and on June 2 ('92), two birds about ready to leave the nest. On February 26 ('93), two eggs were collected at Munt Vernon by E. M. IIasbrouck. The nest being used for years, sometimes attains considerable size, eight feet across the top and seven feet high, is the largest one I have measured.

In confinement at Toledo, Ohio, two eggs were laid, incubation commenced on March 26, ' 86 , and one bird was hatehed on April 26; on Mareh 18, '\$8, she again started to incubate 


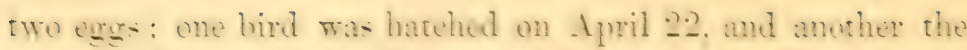

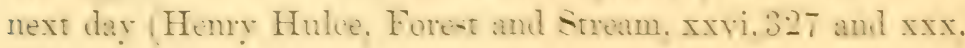
258).

Falco peregrinus anatum (356). Duck Hawk.

.. Iniversally, but irrezularly Uistrilnted in Jourh America. sarely to be con-ileral common anywhere hrouls $a$ - far south as Tirginia at least, usually in mountainous regions" (Ker, 536). "Xests sparingly from $35^{\circ}$ north" (Bendire, 2022). On March 5 ('S7, Fisher), one was seen at Grace's Quarter, but it kept out of range. On December 10, 94 , one mas brought alive to haltimore by a cunaryman, and livel for about four month in the window of Jo. $20 \mathrm{~S} \mathrm{E.} \mathrm{Baltimore} \mathrm{street.}$

"Mr. W. T. Roberts got a female on Torember $16,: 79$, at

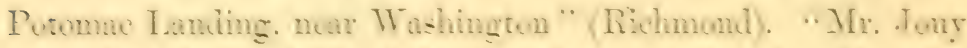
state- clat the Duk Hawk has beon knowa to heed at Harper" = Ferry" (A. C., ST). In reference to this, Mr. II. H. Fisher

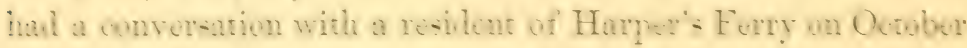
10, :93. He was not acquainted with the "Duck Hawk," but stated that the "Rock Hawk" nested on the face of the Mar" land Heights, and that the site of the nest could be easily located by the "white-wash" after the roung were hatched.

This sprevies is repurten as regularly brealing along the susquehanma in Lamoste? and Tork (wontiss. Po. In the latter county a set of fisur slighty im ubuted egg- was calien (n April 7. : \$0, br M[r. Greo. Miller (Birds Pa., 137).

\section{Falco columbarius (35i). Pigeon Harrt.}

"Thole of Sorth America, breeding chieftr north of the Cunited States" (Manual, 250). "Doubtless breeds in the monntainou- portions of some of che Southem states" (Bendire, 289).

I have but few notes on this powerful little hawk. On

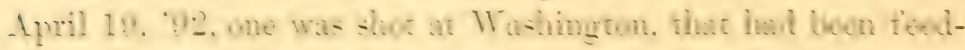
ing on a Sparrow-hawk (Fisher's Hawks and Owls, 113). On April 26, :95, one was shot near Bay Tiew by at. Wolle, 
it had been feeding on a Snow-bird. On April 30, '93, in Dulaney's Valley two birks swished chere past me making for a small scrubby thorn bush, round which they went several times; finally one darted into its entre, the other kept round once more and lit on top. I then saw that they were a Catbird and a Pigeon Hawk, the hawk seeing me flew, but the ('athird remained apparenty thoroughly exhamsted. (On odober :30, '92, I surprised one feeding on a dove. A not uncommon migraut at Washington (Richmond). "N1. F. Is. Washburn, of Johns Hopkins University, hats reported to the Igriendtural Department that he observed several pairs, apparently breding at Harper's Ferry, April 12, '87' (Birds Vas., 62).

\section{Falco sparverius (360). American Sparrow Hawk.}

Resident, common, but most numerous during the migrations of small bird. Henee, on Mareh 18 (a), Wholey and Giray) about 75 were seen in Dulaney's Valley. I) hring summer they are not often seen exerpt in the lowality of the nest. Dates for eggs range from $A_{\text {pril }} 17$ (95, I I munghoure) to May 28 (9)

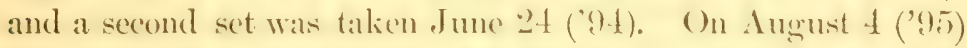
flying young were still being fed by the parents. Sets are 9 of 4 and 6 of 5 .

\section{Pandion haliaëtus carolinensis (36t). American Osprey.}

Common summer resident on all om latrerer waters, extremely numerous on the arms of the ('hesapeake. ()n Mitreh 11 ('93, Blogg) five were seen at Fulton Avenue. On the Eastem Shore it is mantained that they always arrive on st. P'atrick's Day, March 17. Mr. Sharpis attention wats ealled to this, and he reported that the first himel arrived at liock Hall on Matreh 1t, '95. Late in September most have gone south, but they have been noted later, the last on November $\$(92$, Blogg).

On April 3 ('93) they were patching up old nests at the month of Gunpowder, and on April 24 ('94, Tylor) sets of fresh eggrs were collected in Talbot comnty, where on August 
19 ('83) I noted a number of' nests with young still in them. Sets are 4 of 1,9 of 2,19 of 3 , and 3 of 4 .

Inland, this bird is seen more or less regularly at Loch Raven, and one was seen as far up the Gunpowder as Cockeysville on April 17, '94 (Fisher). Several were over the Potomac, at Brunswick, on September 26, '93 (Fisher).

Family Strigid As-Barn Owls.

Strix pratincola (365). American Barn Owl.

"Not abundant north of the Carolinas" (Birds N. W., 300). "At Washington, where the Barn Owl is by no means rare, they begin nesting from the last week in April to about May 10" (Bendire, 327). "The National Museum collection contains two eggs of this bird taken from the Smithsonian towers, one in June, '61, the other June 1, '65' (C. W. Richmond, Auk, $\mathrm{v}, 20$ ). On June 28, '90, seven half-grown young were found in this tower (Fisher's Hawks and Ow!s, 136). "On December 8, '93, a young bird that had but recently left its nest was caught, probably hatched some time in October. On February 27 , '95, another of about the same age was picked up in a bush in the Smithsonian grounds. This was certainly not over two months old, and must have been hatehed in the latter part of December, if not early in Jamuary; certainly a most unusual time of the year for this owl to breed in this latitude" (C. E. Bendire, Auk, xii, 180-81).

Uccasionally one is secured anywhere in tidewater Maryland, and they seemed to be more mumerous than usual during the spring of '93. On April 6 one was shot at the Old Marine Hospital; on the 20th, a male at Aberdeen, Harford County; - on the 22nd, another male on Patapsco. Neck, and on July 27th a female and five downy young were taken alive near the Old Marine Hospital, by A. Wolle. 
Family Bubonide-Horned Owls, Hoot Owls, etc.

Asio wilsonianus (366). American Long-eared Owl.

Nocturnal in its habits; this speries is resident, but as far as I know not common, though a locality may yet be found where it is numerous. On April 22 ('9:?, Gray and Blogg), a set of six egg;, nearly hatched, was collected near Randalstown, from an old crow's nest about 20 feet up a small pine.

"Common resident at Washington" (Richmond); "at Hagerstown one was shot in January" ('79 Small).

\section{Asio accipitrinus (367). Short-eared Owl.}

"It is more than likely that it breeds, occasionally at least, in suitable localities along the borders of the extensive marshes of the sea coast of the southern Atlantic States; by far the greater number, however, breed north of the United States" (Bendire, 332). "Decidedly the commonest owl about Washington, especially in winter" (Birds N. W., 307), where it has been taken in November, January, March and April, and at Sandy Springs it has been taken in December, January, February and March (Fisher's Hawks and Owls, 148-9). On April 1 ('92, Fisher) one was taken at Ruxton. On October 22 ('92, Gray), one at Pikesville; on November 8 ('90, Pleasants), one at Towson, and on December 2 ('93, R. C. Watters), one in Dorchester County.

\section{Syrnium nebulosum (368), Barred Owl.}

Resident, numerous "down the necks," otherwise fairly common round Baltimore. March 16 ('95, Fisher), one fresh egg, and May 5 ('94, Fisher), two young birds, four or five days old, are extreme nesting dates. Sets are 2 of 1,4 of 2 , and 1 of 3 .

Nyctala acadica (372). Saw-whet Owl.

While by no means common in winter, a number have been recorded. On Novemuber $13(92, \mathrm{Blogg})$ one flew into a brightly lighted room in the city. On December 23 ('75, 
Resler) one was taken alive, and on March 4 ('94, Tyler and Fisher) another was taken alive at Bird River. 'The records of the Maryland Academy of Sciences show one presented on May 15 ('79), possibly a mounted specimen.

Quite a number are recorded from the District of Columbia and adjoining portions of Maryland. F. W. Webster notes eight obtained early in October in different years (Auk, iv, 161). One taken on November 1 ('78) ; one on February 12 ('59), and one on March 12 ('S9) (C. IV. Richmond, Auk, vi, 189). One on December 12 ('90); three on January 4 ('91), and one taken alive in the Smithsonian on February 4 or 5 ('91) (E. M. Hasbrouck, Auk, viii, 313); one on November 1 ('S9) (Fisher's Hawks and Owls, 162), and another at Ivy City, on December 3 ('89) (W. A. Merritt, Oologist, viii, 313).

\section{Megascops asio (373). Screech Owl.}

Common resident and generally dispersed, but more of ten heard than seen. I have heard them all through winter at Waverly, Baltimore City, where on January 16, '92, at 7.30 P. M. one was "laughing" as merrily as in June, though there was 6 inches of snow on the ground. Nesting dates range from April 4 ('92), 4 fresh eggs, to Jume 4 ('93), 3 birds just hatched, while on July 24 ('93) young nearly grown were still being fed by the parents. Sets are 2 of 2,5 of 3,9 of 4, and 3 of 5 . As far as I know the gray and red phases of plumage are about equal round Baltimore.

\section{Bubo virginianus (375). Great Horned Owl.}

Common resident, but most numerous in heavily wooded sections of the state, especially in tidewater Maryland. On February 11 (94, Tylor) two fresh eggs were taken on the Virginia sile of the Potomac, near Alexandria. On February 25 ('95, Tylor), two eggs, one-third inculated, at Magnolia. On April 2 (93), one bird about 2 weeks old at Bush River, and on April 12 ('93, A. Wolle), 2 eggs "down the necks." 
In Dulaney's Valley on March 10 ('95) a nest was found with an egg about to hatch and a young bird not 24 hours old, and on April 24 ('92) two young birds just out of the nest were captured alive.

Sets are 1 of 1,8 of 2,1 of 3 , and early in April '91 four birds just out of the nest and sitting together on a limb were seen in Talbot Connty, two of these were captured and raised in confinement (Tylor).

\section{Nyctea nyctea (376). Snowy Owl.}

More or less numerous in Maryland during severe winters, this species cannot at any time be called common. Quite a number are on record from all over the state, but I cannot get exact dates.

\section{Order PSITTACI-PARROTS, ETC.}

Family Psittacida-Parrots and Paroquets.

Conurus carolinensis (382). Carolina Paroquet.

Originally well known in tidewater Maryland, the only occurrence for many years is recorded as follows: "In September, '65, while gumuing for Sora on the Potonac River, Mr. Ed. Derrick fired into a flock of strange birls flying overhead, killing several which proved to be Carolina Paroquets. He had one mounted and kept the specimen in his house for a number of years. Other parties on the marsh at the same time shot numbers of the birds" (H. M. Snith, and Wm. Palmer, Auk, v, 148).

\section{Order COCCYGES-Cuckoos, KingFishens, ETC.}

Family Cuculide-Cuckoos, etc.

Coccyzus americanus (387). Yellow-billed Cuckoo.

Common summer resident, but more often heard than seen. Extreme dates are April 2S ('SS, Resler') and Octoher 14 ('91, Resler). Nests with eggs have been found from June 7 ('93, 
Fisher) to August 23 ('91). As far as I have been definitely able to note sets, they are 6 of 2,3 of 3 , and 2 of 4 . I have found nests with all the eggs in the same state of incubation and others with various stages, from large young birds to eggs in different stages of incubation. At Vale Summit they were fairly common, on June 9 ('95) a nest contained 2 fresh eggs.

Coccyzus erythrophthalmus (388). Black-billed Cuckoo.

A common migrant and rare summer resident. May 8 ('s9, Resler) and May 21 ('93, Wholey) seem extremes of the spring movement, and August 4 ('95) to October 3 ('93, Wholey) cover the fall. On September 28 '92, (Wholey) "they were the most numerous birds seen in the woods."

On July 7, '93, (Gray) a nest with one young bird and 3 nearly incubated eggs was found at Calverton, while further out the Franklin Road, in an overgrown corner, two broods were raised the same year.

At Washington it is noted as "rare from May 2 to the middle of October" (Richmond). At Hagerstown, noted in July, August and September ('S0), and from May 11 to September ('81, Small). At Vale Summit, on June 14, '95, I found the nest, containing 2 eggs about one-half incubated, of the only pair there.

Family AlCEdINId Æ-Kingfishers.

Ceryle alcyon (390). Belted Kingfisher.

Abundant during spring, summer and fall; a number winter in tidewater Maryland during mild seasons, only leaving when frozen out. The nest tunnel, in a bank, preferably but not always over water, is remarkably close to 4 inches in diameter and usually about 5 feet long, though I have seen two of not quite 2 feet and one of over 10. As a rule they go straight in but occasionally they make a beud. The nesting liole at the end is rounder in the shape of a flattened sphere and averages 16 inches across by 8 inches high. In this, the first egg is laid on the bare ground, but by the time the eggs hatch about a quart 
of loose fish seales and bones have accumulated. May 9 ('92, Blogg), 5 fresh eggs, and May 31 ('92), one fresh egg, are extreme dates; full sets are 3 of 6 , and 6 of 7 .

\section{Order PICI-WoODPECKERS, ETC.}

Family PICID五-Woodpeckers.

Campephilus principalis (392). Ivory-billed Woodpecker.

However the distribution of this species may have been, it is now very restricted. Audubon says (iv, 124): "On the Atlantic coast North Carolina may be taken as the limit of its distribution, although now and then an individual of this species may be occasionally seen in Maryland."

\section{Dryobates villosus (393). Hairy Woodpecker.}

Resident, but not common, and, as it is usually found in heavy timber, appears much rarer than it really is. On June 2 ('94, Fisher) a very noisy pair evidently hat a nest, but it was not found owing to lack of time. Young of the year were noted on July 10 ('92) and on August 20 ('93). On May 8 ('95, H. C. Oberholzer) a pair were feeding young near the Great Falls of the Potomac, on the Maryland side.

\section{Dryobates pubescens (391). Downy Woodpecker.}

Common resident. Nests with eggs have been noted from May 4 ('91) to May 2.2 ('93); the set being 5. On .June 8 ('84) young were nearly ready to leave the nest, and ou July 4 ('9:3) young not long out of the nest were seen.

Dryobates borealis (395). Red-cockaded Woodpectier.

"Pine swamps and barrens of South Atlantic and Gulf States, north to Penncylvania " (Key, 451); "irregularly north to New Jersey" (Manual, 283). Dr. Ezra Meichner in his Catalogue of (hester 'ounty Birds, published in 186is, writes, "accidental, very rare" (Birds Pa., 167). 
Sphyrapicus varius (402). Yellow-bellied Sapsucker.

Common during migrations, September 27 ('79, Resler) to October 26 ('94), and again from March 12 ('92, Gray) to May 2 ('93, Fisher). No doubt this species winters in southern Maryland, as specimens have been talien near Baltimore on November S ('St, R hler); November 12 ('92, Gray); November 26 (93); December 6 (98), J. H. Fisher, Jr.); December 24 ('92, Blogg), and January 1 ('92, Resler).

At Washington, "J. D. Figgrens got one on January 14, 'SS; one was shot February 15, about '59, and one was seen about the middle of January, '94" (Richmond).

At Hagerstown they were noted during January and December, '79; January, February, March, October, Norember and December, 'so, and from January right along to July, and also in October, 'S1 (Snall). On July 6, '95, (Tylor) adults feeding young were noted at Deer Park.

Ceophlœus pileatus (405). Pileated Woodpecker.

Fairly common in the heavily wooded parts of Maryland. Early in June '95 a nest was found by Mr. L. D. WVillis near Church Creek, Durchester County. It contained 3 eggs; 2 nearly hatched, thie other rotten. It measured 2 feet 2 inches deep by 8 inches in diumeter, the entrance was $5 \frac{1}{2}$ inches across and 20 feet from the ground, in a rotten stub. November 17 to 22, '94 (Fisher), quite a number were scen in Somerset County, and one was observed to enter a hole in a stub.

"Mr. Pahmer has 3 specimens bought in market (Washington) on the 9th of January, '79, which had been shot in Maryland, near the District line" (A. C., 81-2). "Said to be not rare at Johnson's Gully, Maryland, near Marshall Hall, and about 14 miles from Washington. Must be quite common in Virginia, as a market gunner brought me nine at one time. He would not disclose the locality, but said it was in Virginia" (Richmond). Quite a number are exposed for sale in our Baltimore markets each winter, but they are all said to come 
from Pennsylvania. On November 7, '91, I saw one that had been shot in Carroll County.

"The Indian hen used to be common round Cumberland, but is now very rare" (Z. Laney).

Melanerpes erythrocephalus ( 406$)$. Red-headed Woodpecker.

This very erratic species, common one year in a certain locality and the next entirely absent or only in limited numbers, is resident, migratory or anything else, apparently at its own sweet will. During the severe winter of '92-3 Mr. W. N. Wholey and I had 8 or 10 birds that we went out regularly to see. They were resident in localities about onc-half mile apart and stayed all winter; one was very noisy, the others were silent. The following winter none remained. May 3 ('91) and June 19 ('92) are extremes for eggs. Sets are 3 of 5, 1 of 4, and 1 of 3. As a rule they dig their own holes, telegraph poles being of ten used, but on May 3, '91, I found three fresh eggs in a hollow $\log$ leaning against a fence. The entrance was 15 inches from top to bottom and 4 inches across, while the eavity only went down 6 inches.

At Washington "not very common and local. It usually spends the winter in smaller numbers, or else keeps more secluded" (Richmond).

Melanerpes carolinus (409). Red-bellied Woodpecker.

This southern species is not cormon around Baltimore. Occasionally noted from August 3 ('87, Resler) to May 16 (91, Blogg). "Rather common near Laurel, where it is a permanent resident" (Richmond). At Washington it is given as "a permanent resilent, rare" (A. C., S3); "very rare, Mr. Henshaw saw an individual about the last of May, 'S7" (C. W. Richmond, Auk, v, 21). In Queen Anne's County they were quite numerous on March 4 and 5, '93, though there was 12 inches of snow on the ground, and the thermometer went down to $8^{\circ}$ during the intervening night. 
At Princoss Anne, Somerset County, they were rather common from November 13 to 22 ('94, Fisher), and Mr. E. G. Polk writing from there, says: "They stay here all summer, ai least until after cherries are ripe, as I have shot a number out of the trees, where they were stealing cherries."

\section{Colaptes auratus (412). Flicker.}

Common riskent, more numerous during migrations. April 28 ('94, Tylor'), in Talbot County, and May 12 ('95), near Baltimore, to June 23 ('93), are extremes for eggs. Sets are 1 of 2,3 of 5,4 of 6,2 of 7,3 of 8,1 of 9,1 of 10 , and 1 of 11 . Flickers usually dig their own holes, but they will nest in natural cavities and various other places; if undisturbed, using the same site for years.

Order MACROCHIRES-Gontsuckens, Swifts, HummingBIRDS, ETC.

Family Caprinulgide-Nighthawks, Whip-poor-wills, etc.

Antrostomus carolinensis (416). Chuck-will's-widow.

North, regularly in summer to North Carolina; in a letter to Wm. H. Fisher, Capt. Crumb says he has taken this species at Cobb's Island, Va.

At Odenton, Anne Arundel County, upon two occasions in July, Prof. P. R. Uhler has observed single birds of this species, their size making them quite conspicuous among the Whip-poor-wills which were quite numerous there.

Antrostomus vociferus (417). Whip-poor-will.

Locally common during summer, it was first heard April 9 ('93, Wholey), and on April 27 ('93, Fisher) they were common, remaining so until September 20 ('91), the last being noted September 28 ('94). It Washington, "to October" (Richmond).

On May 5 ('94, Tylor) one fresh egg was found, and on June 10 ('91, Fisher) one young bird a few days old. 
Chordeiles virginianus (420). Nighthawk.

About equally numerous and just as local as the Whip-poorwill, from April 29 ('93, J. H. Fisher, Jr.) to October 15 ('92, Blogg). At Washington, April 20 (Richmond). In fall, large flocks migrating are noted from August 29 ('94) to September 25 ('92, Wholey). Nesting on the bare ground, this species has discovered an excellent substitute in the flat roof's of the houses of Baltinore City, where a large number breed. On June 8, '91, one young bird a few days old was seen within stone's throw of the City Hall, and on July 31, '94, two young birds were flying after their parents.

Family Micropodid E-Swifts.

Chætura pelagica (423). Chimney Swift.

Common summer resident from $A$ pril 16 ('91) to October 4 ('93); extreme dates are March 30 ('95, Blogg) and October 17 ('88, Resler); at Hagerstown, April 6 to October 16 ('so, Small); at Cumberland, April 5 ('95, Z. Laney).

On May 15 ('92) a pair were scen mating, but they were not noticed breaking twigs until June 3 (94); eggs were in nests on June 19 ('81), and young birds f'ell down the chimney on August 27 ('93). Sets are 2 of 5.

Family TrochILIDE-Hummingbirds.

Trochilus colubris (128). Ruby-throated Hummingbird.

Common summer resic!ent; first noted at Washington on April 28 (Richmond) and numerous around Baltinore from May 1 ('92, Resler) to September 25 ('92); the latest date is October 3 ('88, Resler), when one was perched on a telegraph wire in the city, and ('90, Wholey) when one was taken. The usual set of two eggs is noted from .Ture 2 (93), J. H. Fisher, Jr.) to July 10 ('92, Blogg). 


\section{Order PASSERES-PERCHINGBIRDS.}

Family Tyrannide-Flycatchers.

Milvulus forficatus (443). Scissor-tailed Flycatcher.

"A Milvulus probably $M$. forficatus is given in the original edition as having been obtained by Mr. C. Drexler, on May 6, '81. We have never been satisfied of the accuracy of the information, even supposing veracity on the part of our informant, and in our remarks on Mr. Jouy's list, we spolie as if inclined to drop the species from the list; but we have no more authority for doing so than for retaining it, so we make no alteration in a record which, unfortunately, must always remain dubious" (A. C., 75-6). One "was sent to the Smithsonian Institute by Mr. R. B. Taylor, of Norfolk, Va., . . shot on January 2, '82 in his door yard in that city" (Robert Ridgway, Auk, viii, 59). Under date of May 5, '93, Capt. Crumb states that he has secured a specimen at Cobb's Island.

\section{Tyrannus tyrannus (444). Kingbird.}

Common summer resident from April 14 ('95), to September 15 (93, Gray). On September 23, '91, I saw a single bird 2 miles north of Martinsburg, W. Va., and at Hagerstown they are noted from April 13 ('83) to October ('79, Small). During migrations they appear in flocks, sometimes over 100 being together, these have been noted from April 30 ('93) to May 3 ('93, Fisher), and from August 4 ('95) to September 7 ('94). Extreme dates for eggs are May 31 ('93) and July 17 ('92). On August 12 ('94), young were still being f'ed. Sets are 1 of 1, 1 of 2,13 of 3 , and 3 of 4 .

\section{Tyrannus verticalis (447). Arkansas Kingbird.}

"This is a western species added to the list in '77, by Mr. Jouy, who found it in the flesh in market September 30, '7t. In point of fact, it was not actually got in the District, but in some adjoining portion of Maryland. There is no doubt about 
the bird, as the specimen is preserved in the United States National Museum. (Snith. Report, '74-5, 32. Jouy's Catalogue, '77, 5 and 11)' (A. C., '76).

\section{Myiarchus crinitus (452). Cxested Flycatcher.}

Common summer resident from April 29 ('93, Gray), to September 2 ('93, Gray); extreme dates are April 27 ('93, Gray), and Septembrir 21 ('94). Eggs are recorded from June 6 ('91), to July 9 ('93). Sets are 1 of 3,1 of 4,4 of 5 , and 2 of 6 .

\section{Sayornis phœbe (456). Phœbe.}

Common from March 18 ('94) to October 17 ('94), quite a number of single birds have been olnserved during the remainder of the year. This year ('95), however, they have been abser.t; a few were observed between March 31 and May 13, after which none were seen until September 15.

Extreme nesting dates are April 8 ('94), a nest ready for eggs and July \& ('94), eggs nearly hatched. Sets are 3 of 3, 10 of 4,13 of 5 , and 1 of 6 .

At Hagerstown, under date of January 26, '\$2, Small says : "Has probably been with us all winter, was seen December 8 and 26, and January 18, 19, 20 and 21."

\section{Contopus borealis (459). Olive-sided Flycatcher.}

Rare migrant. "The claim of this species to a place in our list (of the District of Columbia) rests upon Mr. Ridgway's observation near Fall's C'hurch, Va., where several birds were noticed in September,'S1. Further west in Virginia, the species cannot be considered very rare, individuals having been observed for 3 or 4 successive summers by one of the authors, and Dr. A. K. Fisher has taken a specimen in the Bull Run mountains" (H. M. Sunith and Wm. Palmer, Auk, v, 148).

"Judge Libhart states that this species (probably 15 or 20 years ago) was found as a breeder in Lancaster (County, where, however, in recent years it has been observed by Dr. Treichler only as a rare spring and fall migrant" (Birds Pa., 194). 
Contopus virens (461). Wood Pewee.

Common summer resident; first noted on April 25 ('85, Resler), when one was taken, and numerous on May 8 ('94). A number were noted October 15 ('93), and two days later ('83, Resler) one was taken. Nesting dates range from June 8 ('92, Blogg), a set of fresh eggs to September 12 ('92, Wholey) young birds not able to fly far. Sets are 1 of 1,5 of 2 , and 7 of 3 .

Empidonax flaviventris (463). Yellow-bellied Flycatcher.

Migrant, not common. Spring notes are few. On May 14 ('93), a male was taken and 4 days later another, 3 days after which 5 were seen (Wholey). On May 16 ('83), and 19 ('93), single birds were taken (Resler). During fall they are frequently recorded between August 31 ('93, Gray) and October 6 ('94).

At Washington, a "spring and fall migrant arrives first week in May and we have seen it in the fall until the third week in September. One shot July 28," (A. C., 78) "migrant during whole of May, and August and September" (Richmond). "Tolerably commou migrant near Washington, generally in the scrub pines" (Dr. A. K. Fisher, Birds Vas., 67). This last observation may account for its not being more frequently noted near Baltimore, as but a small percentage of our local observations have been made among the pines.

Empidonax virescens (465). Acadian Flycatcher.

First noted on April 30 ('93, Wholey), and common from May 11 ('94,) to August 24 ('94 and '95,) the last was recorded on September 11 ('94). On May 31 ('91,) a nest was ready for eggs and on July 30 ('93, Fisher), one contained eggs ready to hatch. Sets are 28 of 3 , and 1 of 4 .

Empidonax traillii alnorum (622a). Traill's Flycatcher.

Rare migrant. On May 5, '93 (Resler), one was taken at Back River, and on May 11, '93, (Wholey) another at Waverly. "One 
was taken by the writer on May 13, '8S, at the Fotomac River, Alexander County, Va.; another by Mr. Ridgway on May 18,'88, at Laurel, Maryland, and a third by myself on May 19, '88, in Virginia, opposite Georgetown. Several others were subsequently seen and ohservel" (Wm. Palmer, Auk, vi, 71), "This has always been regarded as the rarest of the flycateher's ; very few having leen taken up to the present year ('92). On and about May is for several days they were quite common and a number were taken" (E. M. Hasbronck, Auk, x, '93). "Common at times, I saw sereral on May 23, '91. Wm. Palmer shot one on May 10, '14, and another on August 27, 'S9, and I shot one on September 17, '90" (Richmond).

Empidonax minimus (467). Least Flycatcher.

Rare migrant, specimens have been taken on April 29 ('93, Gray), on April 30 and May 7 ('92, Pleasants), on September 11 and 25 ('93, Gray), and September 28 ('92, Resler). At Washington, "common from April 25 to May 25 and from August 28 to September 25 " (Richmond).

On Din's mountain, June 5 to 14 , '95, three or four pairs were mating in a grove of heavy timber.

Family Alaudid đE-Larks.

Otocoris alpestris (474). Horned Lark.

Irregularly abundant in flocks, which are sometimes quite large, from November 10 ('94, Gray), to March 19 ('92, Gray); they are most numerous in tidewater Maryland. At Washington, from the first of November to April (A. C., 41).

Otocoris alpestris praticola (474b). Prairie Horned Lark.

This sub-species appearing in company with alpestris can only be identified by close comparison with a series of specimens. One, of several shot at Powhatan, on February 25 ('93, Gray), was pronounced of this sub-species by Mr. Ridgway. 
"Two in the collection of $\mathrm{Wm}$. Palmer have been identified by Mr. Henshaw as belonging to this race; they were taken in February,'s1, and were in company with numbers of Otocoris alpestris. On February 16,'ss, eighteen specimens of this variety were taken by $\mathrm{Wm}$. Palmer, near Washington, from a flock of 50 or 60 birds that had been noted in the vicinity throughout the winter. About half a dozen other specimens have recently been obtained by various collectors" (H. M. Smith and Wm. Palmer, Auk, v, 148).

\section{Family Corvidæ-Crows, Jays, etc.}

\section{Cyanocitta cristata (477). Blue Jay.}

Common resident. A pair were mating on April 13 ('93), and eggs were collected, 5 on May 13 ('S2) and 4 on May 30 ('94, Tylor).

\section{Corvus corax principalis (486). Raven.}

Now rare in Maryland, but, without doubt, may be credited to our ocean front and also to the mountains of Western Maryland. During Christmas week '92, about 20 were seen at Bayard, W. Va., but they could not be approached within rifle range. On December 6, '93, several were seen at the same place (J. H. Fisher, Jr.). Bayard is within 5 miles of the Potomac. During July, 's0, Ravens were found on Cobbs, Boone and Mockhorn Islands (Robert Ridlgway, Auk, vi, 118). Recorded from Franklin, Somerset and York Counties, Pa, (Birds Pa., 202). One was taken at Hagerstown in October, '80 (Small).

\section{Corvus americanus (488). American Crow.}

An abundant resident; scattered over the country in summer, and gathering into large "roosts" in winter. They had started roosting on October 21 ('94), and were using it in numbers from November 4 ('94) to March 24 ('95), but I only saw a few on March 31. A nest with 3 fresh eggs on March 13 ('SS, 
Wholey), and another with 1 fresh ege on May 132 ('S2), ar extreme dates. Young were still in a new on June 5) (') (1)' and

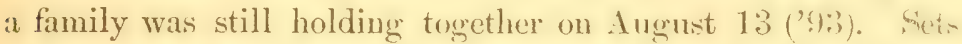
are 3 of 2,3 of 3,18 of 4,22 of 5,1 of 7 , and 1 of 10 . On Dan's Mountain I only saw 5 or 6 crows from Jume 5 to 14 ('95).

Corvus ossifragus (490). Fish Crow.

Resident in tilewater Maryland. Five eggi nearly incribated were taken at Gumpowder on May 21 ('): Fi Fisher), 5 in

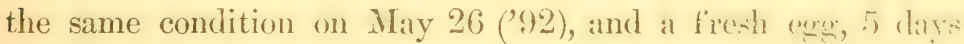
later, were collected in Queen Anne County. On Jun S (') 4 ), 5 eggs, about to hatch, also 1 fresh egg were, noted at Gecan City. This last nest was only $\&$ feet from the gromol in an alder bush (Alnus maritima), the others were all in the tope of high trees.

Family ICTERIDA-Blackbirds, Orioles, ete.

Dolichonyx oryzivorus (494). Bobolink.

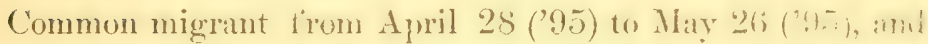
from August 9 ('9-1) to November 8 ('88, Resler). Usually

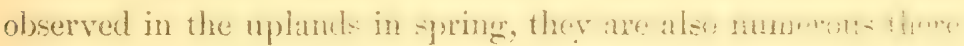
in the fall, while the marshes are alive with them. In April, '95, seven were shot from a flock at Cumberland by '/. Lamey.

\section{Molothrus ater (495). Cowbird.}

Resident; wintering in tidewater Maryland, they are shdum:

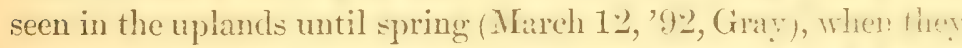
become numerous, but the majority soon go north, amd cincint summer their presence is chiefly shown by the alien cys in the small bird's nest. In fall, however, flocks of any number un to 300 or 400 are frecquently seen between Septembur 16 i $: 414)$ and November 19 ('94). On November 11, '1, I canc aros: an enormous flock of birds, 10,000 , or more; they entirny conered a 25-acre field. Careful investigation with a heln ylan showed about equal numbers of Cowbirds and Red-winged Blackbirds. 
Extreme nesting dates are May 21 ('93), when 2 egrgs were in a Rolin's nest with $: 3$ of the owners, and August 25 ('95), when a young bird was being fed by Indigo Birds. As a rule, only one exrg is found in a nest in Miaryland; the only instance of more, beside the one mentioned above, that I know of, is 3 in a Wood 'Thrush's nest with one of the owners, foumr in 'Talbot County on July 25, '95 (Tylor).

Xanthocephalus xanthocephalus (197). Yellow-headed Blackbird.

Near Baltimure specimens of this western bird have been taken as follows: On September 10,' ',1 a male was shot from a flock of Red-winged Blackbirds feeding in a wild oat marsh near Curtis Bay by Mr. Otto Nickel, who presented it in the flesh to A. Resler, in whose collection it now is. On September 18, '93, a female was shot from a bunch of Blackbirds at Patapsco marsh by Richard Cantler; this I secured for the Maryland Academy of Sciences. On October 1, '94, Mir. Edwin Selıenck got another female at Patapsco Marsh; it was flying by itself. This one had the feathers removed by an over-active cook.

"A female was brought me on August 29, '92, that was killed from a flock of Blackbirds on the marshes adjoining Washington. 'This in the first record for the District of Columbia" (E. M. Hasbronck, Auk, x, 92).

\section{Agelaius phœniceus (498). Red-winged Blackbird.}

Resident in tidewater Maryland, but not found in the uplands during winter. Nesting among the reeds, grass or bushes of swamps or wet meadows, I wats rather surprised when a nest was found in a wild aster on top of a hill and fully a mile away from the nearest piece of swanp and one-cighth of a mile from the rum. On Mlay 13 (') t, Tylur) eggs were found in Talbot County; near Baltimore, from May 18 (90) to July 26 ('81). Sets are 1 of 1,10 of 2,44 of 3,30 of 4 , and 3 of 5. At Vale Summit I only noted a single female on June 13, '95. 


\section{Sturnella magna (501). Meadowlark.}

Common resident; numerous in flocks in spring and tall. On May 10 ('91, Wholey) 2 fresh eggs were found and on July 21 ('95) 5 fresh. Sets are 1 of 4,5 of 5 , and 1 of 6 .

Only a few at Vale Summit, June 5 to 14, '95.

\section{Icterus spurius (506). Orchard Oriole.}

Common summer resident. First noted at Washington on April 25 (Richmond); at IIagerstown, April 30 ('79, Small), at Knoxville, May 4 ('94, Fisher), and at Baltimore, May 5 ('95), while on May 7 (93), they were common. They leave as soon as the young are able to go with them, and but few individuals are seen after August 4 (95); the last on September 8 (95).

Eggrs are noted fom May :;() (') '?), to July 12 ('83). Sets are 2 of 3,2 of 4 , and 3 of 5 .

Only one pair was at Vale Summit, June 5 to 14, '95.

\section{Icterus galbula (507). Baltimore Oriole.}

Locally common churing summer. On April 29 ('93, Gray) both males and females were olserved, but that they arrive earlier is shown by a pair having started to build on Maly 2 ('91). They are numeromily peomeded until September s (95), a fow until October 6 ('94).

At Waverly a pair started to build on May 2 ('91), and finished the nest on May 1.t. The year before they did not start until the 15 th, and the nest was finisherl on the 21 st; both were placed quite close torgether and within 20 feet of the veranda. On June 7 ('S2) a nest contained 2 fresh eggs; on June 23 ('95) young were in a nest, while flying birds were still being fed on July 21 ('95).

At Hagerstown they were noted on April 27, '80, on May 12 they were building, and on the 1 sth they har exgn (Nmall). At Vale Summit, June 5 to 14 , '95, they were numerous, the nests containing either eggs or small young. 
Scolecophagus carolinus (う()). Rusty Blackbird.

Very common duringr migration; quite a number winter in tidewater Maryland. First noted in a large flock on September 30 ('9-t), the last were talien Mar 7 ('sis, Resler). As a rule, they mite with floxks of Cowhirk, Rich-winged Blackbirds or Purple (riackles, lut sometinn they are seen in flocks by themselves.

\section{Quiscalus quiscula (511). Purple Grackle.}

Resident; it takes remarkably severe weather to drive this species from tidewater Maryland in winter. In the uplands they are numerous from March 1 ('95) to July 20 ('95) and not uncommon until early in November. Nests with erges are recorded from A pril 28 ('94, Tylor) in 'Talbot C'ounty and from May $6(92)$ in Baltimore ('ounty, until Jume \& ('St). Sets are 2 of 2,5 of 3,5 of 4,13 of 8 , and 4 of 6 . Nesting anywhere, a bunch of cedars seems to be preferred. 'The nest is usually placed in a crotch, but other situations are frequently chosen, notably the spaces in the rough sides of the Fish Hawk's nest. On May 14, '81, I found one in a hollow of a tree not seven feet from the ground, and on May 22, '92, another in a partially torn out Flicker hole. In 'y1-2-3, they nexted inside the barn on the Mamplen property, in Dulaney's Valley, placing their nets on the rafters and roof-sill (J. H. Pleasants, Jr.,).

Quiscalus quiscula æneus (511b). Bronzed Grackle.

"Occasionally east af the Alleghanies, from Virginia north-

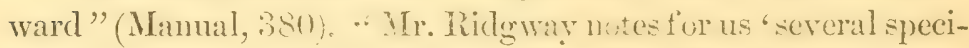
mens seen' but concile's it 'ralle.' Mr. Wr. Palmer notes one in

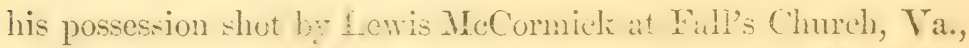

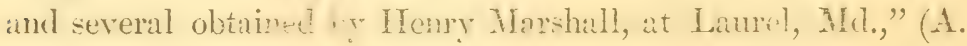
C., 73). One was sliot in Prince George's County, by Fred. Zuller, (Smith. P'riont, 's, Sü), and another at Laurel, Mid., by George Marshali (Joid. 724 ). 
"Little more than a straggier, and individua mang through here hardly remain to breed. However, I have a male shot April 6 , 'S6, a ciar when ordinary quiverle is wing, and at female shot April 2, '\$7, about the time ordinary quiscala are laying their first eggs" (C. W. Richmond, Auk, v, 19).

I have a male taken on March 1, '95, in Dulamey's Valley, and careful investigation, at short range with a fiehd glase on

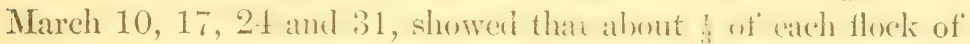
Grackle's were referable to this race. On April 21, '95, at least one male was observed.

\section{Quiscalus major (513). Boat-tailed Grackle.}

This species nests in the stunted pines and alder bushes

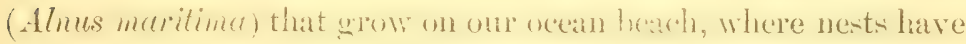
been found by Mr. C. W. Dirickson, of Berlin, and on July 7 , '92, Mr. W. N. Wholey found a colony near Ocean City, the

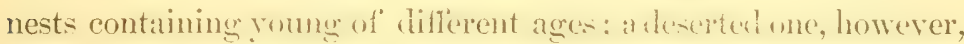
held 3 rotten eggs. In June, '94, I visited this locality and

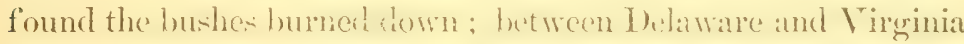
I did not see a single grackle.

On May 6, '93, one was with a flock of Purple Grackles at 'Townsend Street just west of Fulton Arenue (Gray), and on May 17, '93, one was noted at North Point.

A small colony was found at Smith's Island, Va., where they were breeding; cures and small young loing found, May 16-24, '94 (Richmond).

Family Fringildide-Finches, Sparrows, ete.

Pinicola enucleator (515). Pine Grosbeak.

I can find no reference to this species, except that Dr. Coues says: "Northern border" of United States in winter, sometimes south to Maryland" (Key, 343). "An extremely rare and probably only accidental visitor in severe winters" (A. C., 56). "Occasionally to Maryland" (Birds N. W., 105). "We have no recent records, and the old ones are mere traditions- $i$. e., we have no precise dates or records of specimens" (Richmond). 


\section{Carpodacus purpureus (517). Purple Finch.}

Common in flocks during winter, they were exceedingly numerous round Baltimore during the severe season of '92-3. Extreme dates are October 1 ('90, Recler) and May 321 ('93, Fisher). At Washington it is wiren as "common in migrations, less so in mid-winter. One was shot September 17 ('S7), by H. W. Henshaw. I saw a flock at Great Falls, MId., on September 24-5 ('S9), and one was shot on May 13 ('S5), by Dr. H. M. Smith" (Richmond).

"Not known at Hagerstown until May 3, 'S3, when they swarmed in the town" (Small).

\section{Passer domesticus. English Sparrow.}

The first English Sparrows brought to this conntry were 8 pairs, liberated in Brooklyn in the spring of ' 51 , but nothing is known of what became of them. Two years later, 100 were liberated there and the importation was kejt $u p$ for 30 years, the birds being liberated at widely different points of the country, 2500 or more birds being introduced.

“In June, '74, a few birls were brought to Baltimore by an English Captain and liberated in Franklin Syuare. These are the first birds we have any knowledge of that came to Baltimore direct" (Baltimore American, August 31, '93). At the following points in Maryland they introdnced thenselves, ${ }^{1}$ ant were noted in the following order :

${ }^{\prime} 65$ Hancock.
${ }^{\prime} 68$ Cumberland.
'70 Williamsport.
'72* Hanchester.
'75* Boonsboro.
'75* Oakland.
'76* Clearspring.
'76* Hagerstown.
'76* New Windsor.
'76* Smithsburg.
${ }^{\prime} 76$ * Taneytown.
'76* Westminster.

$$
\begin{aligned}
& \text { '77* Mechanicstown. } \\
& \text { '77* Union Bridge. } \\
& \text { '78* Frostburg. } \\
& \text { '78* Lonaconing. } \\
& \text { '78 Middletown. } \\
& \text { '78* Sharpsburg. } \\
& \text { '79* Burkettsville. } \\
& \text { '79* Emmettsburg. } \\
& \text { '79* Sandy Springs. } \\
& \text { '80 Grantsville. } \\
& \text { '80 Salisbury. } \\
& \text { * About. }
\end{aligned}
$$

1 For a full account of the introduction, etc., of the English Sparrow, see "The English Sparrow in North America," by W. B. Barrows, United States Department of Agriculture, Division of Economic Ornithology and Mammalogy, Bulletin No. 1, 1889. 
Now they are all over the State and here to stay, being common in the cities and towns, while there is scaredy a house in the country without more or less of them round it. In Baltimore City they are frequently seen building in the winter; these, I believe, are only roosting nests. On May 17 ('91) eggs about one-half incubated were taken, and on August 16 ('91) birds, just hatched, were found. Sets are 2 of 2,2 of 3,9 of 4,7 of 5 , and 2 of 6 .

\section{Loxia curvirostra minor (521). American Crossbill.}

Very irregular in its movements; I have only observed this specics once. (On November 1 1, ')- A, about 25 were feeding on the cones of a smatl scrub pine, at the north end of Dulaney's Valley; they were quite wild, and did not remain ten minutes; when flushed, they flew clear out of sight.

At Lawyer's I Iill, Ioward ('omty, about a half mile from Relay, in March, ')(), Mr. C. (ramble Lowndes found "a flock of about $40 \mathrm{in}$ a small bunch of pines; firing into them, two ame to the ground dead, and sereral others, also dead, humg from the branches by their bills or claws, so that they were dislodged with difliculty. The other's were all killed during a week with a small rifle, and were quite good eating. At night they roosted in a small ravine filled with piues and serub valis, and they spent the entire day in the clump of pines."

On January 15, '91, one was taken at Bush River, by Mr. Basil Sollers. Late in October, '89, two were shot out of' a Hock of about 20 in Talbot County (Tylor). It Cimberland "it is seldom seen; some years acro I killed one out of" a flock with a cane" (Z. Laney).

"On May 23, '\$1, MIr. Geo. Marshall shot two, male and female, from a flock of five, near Laurel, Mr. The female showed ummistakable evidence of having recently incubated. Two days later another male was shot in the same locality" (Smith. Report, '84, 146).

"On May 17,'85, an adult male and a young bird in the striped feather, barely able to Hy, were seen by me in a pine sapling, a short distance beyonl the eity (Washington) limits" (Hugh M. Smith, Auk, ii, 379). 
"For a long time regarded as extra rare and irregular in winter'; in Derember. '87, they were numerous at Washington, and every lomal collector secured a series. Individuals were "alugh: alive in the Smithonian grounds and in the Agricultural Mejartment Park; they were seen until April 19,'8S. In the following wintor they were rather rare. In '90, again they were uncomnum, but remained until late, individuals and flocks heing noted on May 10, 16, 17, 21 and 24. Specimens taken on sume of these dates showed no signs of breeding. I have few records for '91, '92 or '93, except that Mr. Ridgway, who lives at Brookland, D. C., near an extensive patch of pines, observel them all summer in small numbers, and still reports them up to June, '95. In the past winter, '94-5, Mr. Figgins reported then common near Kensington, Md., flocks appearing at short intervals throughout the winter. He mentions seeing lumbirels on March 24; his last date is April 7, when about a dozen wore seen. Mr. R. S. Matthews and I saw two small flocks late in April '95" (Richmond).

Loxia leucoptera (522). White-winged Crossbill.

"South in winter to or beyond $40^{\circ}$ " (Manual, 393). Audubon mentions having secured il specimen "in Maryland a few miles from Baltimore" (iii, 191), and Mr. Henry Marshall has one, shot at Laurel about '74 (A. C., 57).

Acanthis linaria (528). Redpoll.

"Rare an: irreutular, perhaps only an necasional visitant in severe winters" (A. C., 57). One specimen, a female, was taken by Dr. T. H. Bean at Fort Runyon, Ta., on February 19, 'T5" (Wm. Palmer, Auk, xi, 333). Audubon says (iii, 121): "T have seen several that were obtained near Baltimore, Md."

\section{Spinus tristis (529). American Goldfinch.}

Common resident; they commence flocking by the middle of September and hold together until early in June. On April 
30 ('93), however, I saw an early pair mating, the male being in nearly full summer plumage. While no doulth they nest earlier, the first note I have is of a pair building on . July 12 ('91), the latest date is September !) ('94), four fresh eggs. Sets are 1 of 3,3 of 4,2 of 5 , and 1 of 6 . At Vale Summit they were not numerous and still in flocks. Jume 5 to 14,95 .

\section{Spinus pinus (533). Pine Siskin.}

Irregular winter visitor, usually found among the pines. On November 24, '92, yuite a large flock was near St. MIfary's Industrial School; on January 29, "18, a flock of about 20 was at St. George's Avenue, and on Mareh 1, 'T!' (Iiesler), a number were at Bayview.

At Washington, "very abundant sume winter's between October and April ; at times, several years will pass without one being seen" (Richmond).

\section{Plectrophenax nivalis (534). Snowflake.}

Irregular winter visitant in cold seations. () F Fehruary (;, 92 (Gray), a flock of eight was seen at Calverton; on February 10 , '95, two were noted on the Falls Tumpilie near ifclvale, and on the same day (Fisher) two were seen on the drive roment Druid Hill Park lake.

One specimen has been taken at Washington (Richmond).

\section{Calcarius lapponicus (536). Lapland Longspur.}

"South in winter to northern United States, sonctimes (rarely) as far as South Carolina" (Mamual, 404). On Felnumy 10, '95, just after the blizzard, all our roads being impasialle to vehicles, I walked out to Lake Roland. At the point where the Northern Central Railruad crosses the Falls Turmpilie a small part of the bank had been cleared of snow ly the wint. on this weie about 20 Longspurs, with $S$ or 10 Song sparrom: and about 25 Tree Sparrows. They allowed me to approach within three feet. 
"Ou December 11, 's6, while 1). Fishes ami 1 were riding along the road to Falls Church, Va., and distant from Washington perhaps four miles, we sitw a flock of 15 or 20 Horned Larks by the roadside. Scattered through the flock were half a dozen or more Longspurs, one of which was secured. Comparatively little collecting has ever been done about Washington in winter, and to this fact, rather more than to its excessive rarity, is due, I an persualed, the absence of the species from the local lists. Nithough probably not a regular migrant, the species occul's here in small numbers, I am inclined to believe, every hard winter. However, it is to be remarked that the records for this bird so far south are very few" (II. W. Henshaw, Auk, iv, 347).

\section{Poocæetes gramineus (540). Vesper Sparrow.}

liesident; abuudant during migrations from March 20 ('y2,) to May 23 ('93, Wholey), and from September 22 ('95) to December 2 ('9t). During summer they are not very common, and only a few winter with us. On June 19 ('90, J. H. Fisher, Jr.) 3 slightly incubated eggs were taken. At Hagerstown it is given as "not common; occasionally seen in June, July, September and October" (Small). At Vale Summit on June 11, '95, I found one pair feeding young just out of the nest.

\section{Ammodramus princeps (541). Ipswich Sparrow.}

"Breeding on Sable Island, N. S.; in winter migrating along the Atlantic coast south to Virginia." (Mauual 407). "Winter resident along the New Jersey coast; not abundant, though probably regular." 9 specimens are recorded between Norember 16 ('80) and April 3 ('S9) (Birds, E. Pa. and N. J., 112-3).

"Those who "are to visit in winter the bleak, wink-swept sind hillocks of our Atlantic coast will find this bira much less rare than it wats once supposed to be" (Chapman 291). 
Ammodramus sandwichensis savanna (j)t2uj. Savimul Sparrow.

Fairly common migrant, some possibly wintering; noted tron October 6 ('95,) to November 9 ('92, Resler), and from March 18 ('91, Resler) to May 12 (')2, Pleasants). At $\mathbb{W}^{r}$ ashington " 4 were noted on ()ctober 14, 94, (J. 1). Figgins and Wm. Palmer); a few winter" (Richmond). At Hagerstown "quite common during the fall migration of ' $S() "$ (Small). No doubt it winters along our sea-coast for "at (ape May and probably all along the coast of southern New Jersey the Savanna Sparrow is an abundant winter resident" (Birds, E. Pa. and N. J., 113).

Ammodramus savannarum passerinus (5-16). Grasshop)per Sparrow.

A few wintering; this species is common from A pril 10 ('95, Fisher) until November 4 ('94). It is usually flushed f'rom the ground, but during the breeding season it mounts on a weed or even to the top of a fence to sing the very peculiar song from which it derives its name.

Although very numerous in the breeding season, the nest is seldom found, it being plated on the level ground in the open field. Young out of the nest were being fed on June 4 ('93), and on August 11 ('94) birds 4 or 5 days old were in a nest. Sets are 3 of 3 , and 3 of 4 .

Common at Washington from March 30 (95) to k ketoher 21 ('87, Richmond). At Vale Summit a number were ohserved June 5 to 14 , '95.

Ammodramus henslowii (547). Henslow's Sparrow.

"Innown from this region for many year's, this has been considered one of the rarest sparrows, although always found in one or two localities. On May 30, '92, while exploring Johnson's Gully, Maryland, 16 miles south of Washington, a large colony was found" (F. M. Hasbronck, Auk, x, 92). "Not 
uncommon in several localitic near Washington. At Kensington, Maryland, where it is rather common, Wm. Palmer found a nest with young on June 1, 94 , and J. D. Figgius shot 2 on October 14, '94. It is also rather common at Laurel, where, on April 10, 89, Mr. Ridgway shot a male" (Richmond) and Geo. Marshall secured specimens on May $t$ and 221, and August 11, '94. In Howard County, specimens were taken on April 17, and August 3, '93 (Resler).

\section{Ammodramus caudacutus (549). Sharp-tailed Sparrow.}

"Abundant summer resident on the salt marshes along the New Jersey coast and for some distance up the shores of Delaware Bay. Mr. I. N. DeHaven finds a few 'sharp-tails' nearly every winter on the Atlantic (ity meatows, but they are by no means common at this seasun" (Birds, E. Pa. and N. J., 114).

On June $7,9,4$, I found a number along the beach some miles south of Ocean City, Maryland.

\section{Ammodramus caudacuís nelsoni (5.9a). Velson's Sharp-tailed Sparrom.}

"Fresh water marshes of the Eastern Lnited Stater, and during migrations, to marshes of the Atlantic const, Massachusett. to South Carolina" (Manual, 41:). " Iare trancient on the New Jersey coast, though probably of regular oreurener. The least common of the three races of sharp-tailed Sparrows on our coast, it will probably be found to be more abundant in f'all than in spring. Specimens have been secured May a and Octoher 2, '92, by Mr. I. N. DeHaven" (Birds, E. Pa. and X. J., 115).

In Virginia the following specimens have been taken, "one by (. Irexler in September, '(i-), another by E. J. Brown, at ('obb's [sland on May 11, "1.), and a third by medf on $f$ mile Run marsh, Alexandria County, ou septemler 1\&, :13," (Wm. Palmer, Auk, xi, 333). 


\section{Ammodramus caudacutus subvirgatus (5496). Acadian Sharp-tailed Sparrow.}

"Was found associated with the other two races at Atlantic City on October 2, '92, and a number of specimens shot. It appearer to be more numerous than melomi hut less so than true caudacutux. This spresies apsenenty winters further south, for all the winter specimens so far taken by us in New Jersey were candacutus. Doubtless more careful search will show the nelsoni and subvirgatus to be of regular occurence in both migrations"

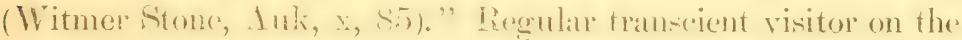
New Jersey coast marshes" (Birds, E. Pa. and N. J., 114).

\section{Ammodramus maritimus (550). Seaside Sparrow.}

"Abundant summer resident on the New Jerney coast marshes and on the shores of Delaware Bay, arrives at Atlantic City about $A$ pril 20 amb departs Oduber 15. In cape Mily ('ounty, Mr. Wr. 1. Baily seened several speeimens Feburary 22, 92, which would indirate that a few of these birds winter there oceasionally" (Birds, E. Pa. and N. J., 115). Between, May 14 and 28, '94, at Smith's Island, Val., they were "breeding and quite numerous, we secured 43 specimens of this bird." (E. J. Brown, Auk, xi, 259). "On Smith's Island I found 3 nests May 18, '94, with 4, 5, and 5 egrs and on May 23,' '94, another with 4 egers" (Richmond).

On May 27,'93, I came accross a pair of these birds, one of which I scuncel, but eareful sourch failed to find the nest. They were in a marsh on Start's Point, between Chester River and Langford's Bay, in Kent County. On June 6, '94, I found a nest with 5 exw nouly hatched, on our ocen front quite close to the Virginia line, where they were rather common.

\section{Chondestes grammacus (552). Lark Sparrow.}

This bind of the Mi the Talley ocentimally strays to the Atlantic coast. "Up to date, our knowledge of the occurrence

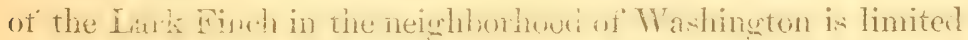


to the capture of a single specimen by Mr. Roberts, on August 25, 'T7 (at Fort Runyon, on the Viginia side of the Long Bridge, A. C., (6) and the observation of 2 individuals in the Smithsonian grounds by Mr. Ridgway (on August 27, '77, Auk, iii, 43). To the above is to be arded the capture of a second specimen, an adult male, on August s, 'S6, by the writer" (H. W. Henshaw, Auk, iii, 487).

\section{Zonotrichia leucophrys (55 $)$. White-crowned Sparrow.}

Regular, though not common, migrant from October 7 ('94) to October 2:) ('92), and from May 6 ('93 and '94, Wholey) to May 21 ('92, Gray), and on the same day at Sandy Springs (Stabler). At Washington, "from October 13 ('93), when several were seen by H. W. Henshaw and A. K. Fisher, to November 25 ('SS), when one was shot by J. D. Figgins, and from the middle of April to May 17 ('86), when one was shot out of a flock of about a dozen" (Richmond).

\section{Zonotrichia albicollis (558). White-throated Sparrow.}

Winter resident; conmon; more numerous during migrations. Noted from September 21 ('3), Gray), and common from Septenber 29) ('95) to May 13 ('92), the latest record being May 19 ('95), when two, a male and female, were found in a brush pile in Dulaney's Valley, and some years ago one was taken on the same date by Mr. A. Resler. At Washington "one was shot on September 15 ('89), and they were common from September 30 ('90, '94) until May 20 ('88), when one or two were noted and a male was shot by W. F. Roberts. On May 21 ('86) one was shot and ('88) several were heard singing" (Richmond).

\section{Spizella monticola (559). Tree Sparrow.}

Equally numerous during winter with the "Snowbird," this species is not so commonly observed, as it does not come round the house, preferring the briar and weed patches. On October 7 ('94) I found it common in Hocks with Snowbirds; and on 
April 29 (94) quite a number were in a Hoek with Field and Chipping Sparrows. At Wakhingten "from late in Oetolen to early in April" (Richmond).

\section{Spizella socialis (560). Chipping Sparrow.}

First noted on March 16 (') 14 ), and common from March 25 (94) to Tovember 27 (')2), s ar 10 were seen on Deember "2 (94), and abotit a dozen (m December 4 ('92). At Washiugton, "some spend the winter, hut not in numbers sufficient to be detected every season. On Mirch 12(')(1, J. D). Figgins) four were seen. Common from the end of March to November 24 ('S9), one was seen on Iecember 1-t ('90)" (Richmond). Mating on April 22 ('94), the firet next with egars was found on May 10 ('91), the last on Alugust 28 ('92), and on Septemher 16 ('94) young just out of the nest were observed. Sets are 2 of 2,27 of 3 , and 14 of 4 .

At Hagerstown their arrival is noted on March 30, '79, March

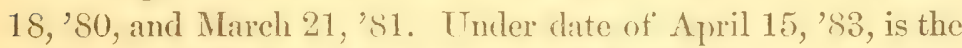
following: "Has any one ever noted the Chippy's fondness for the sap of the grape vine: They malie a regular habit of drinking large (quantities when the vines have heen trimmed in spring. Do they do this for water, or for any nourishment there is in the say): I rather think the latter, as they drink too much for simply quenching their thirst" (Small).

Only a few at Vale Summit, June 5 to 14, '95.

Spizella pusilla (563). Field Sparrow.

This is our most conmon breeding sparow, being exceedingly numerous from March to November. During mild winters, a number stay with us, and exen during the cold winter of '92-:' a flock wass seen on Derember 4 , ahout 20 on Jamuary 4 , and a single bird on Jamuary "2.2. At Washington it is noted as "a common regular winter as well ats a summer resilent" (Richmond). Nests with expre are noted from May $8\left(^{\circ} \div 1\right)$ to Augunt 16 ('91). Sets are 5 of 2,22 of 3 , and 15 of 4 .

At Vale Summit they were not common, Jume 5 to 14 , '95. 
Junco hyemalis (567). Slate-colored Junco.

A winter reident; first noted on September 28 ('93, Gray); it was common on september :30 ('94), but, as a rule, they do not become numerous until the middle of October, remaining so until April 23 (') 3 , Fisher), the last is recorded on May 1 ('74, Resler. '2). At Washington "from September 30 ('94), when several were-een by Messr. Figgins Matthews and Palmer, to April 27 (90), when several were seen. On May 1 ('87), one wati secen and on May 4 ('-) one was shot" (Richmond).

Junco hyemalis shufeldti (567b). Shufeldt's Junco.

A western bird. "On April 28, '90, my son, A. W. Ridgway, shot a female of this sub-species near Laurel, Maryland. It was shot out of a small flock in which, my son thinks, were (ther of the sume lind, but he may have been mistaken" (Robt. Ridgway, Auk, vii, 289).

\section{Melospiza fasciata (581). Song Sparrow.}

Common resident; liable to be heard singing at any time, even in the depth of our most severe winters. Nesting dates mone from thay :3 (") Wholey), 5 fresh eger, to September 11 (92), when young leave a nest. Sets are 1 of 2,5 of 3,13 of 4 , and 8 of 5 . Situations of nests noted show 8 built up from the gromd in bushes, etc., 7 on level ground in grass, and $s$ in hollows in the sides of banks, while one was in the side of a haystack (Fisher).

At Hager-town, Snall says, "one pair has lived in our yard and built two nests each year; averaging from 8 to 10 feet albove the rround; the luwest was 4 feet up, and one was fully -5 feet ${ }^{2} \mathrm{p}$ in a western rine growing against the house. Cowhird egrs were twice deposited, when all the eggs were thrown out ard they started to builit a siew nest the next day. Twice, one of this pair wa lsilled, but a few days later the survivor secured a mate."

Only a few were seen at Vale Summit, June 5 to 14 , '95. 
Melospiza lincolni (583), Lincoln's Sparrow.

"In the Atlantic states it is apparently rare; in the course of all my collecting I never saw it" (Birds, N. W., 136). T. M. MeCormick mentions 2 specimens olstained in the District of Columbia, without date (Auk, i, 397). "Nir. Henshaw collected on the Virginia side of the Potomac 3 speeimens in May, '85. Wm. Palmer has taken 2) birds; and Mr. Ridgway has noted this speeies on several oceasions near Laurel, Md. (Auk, v, 148). "On May 7, '92, J. D. Figgins got one at Kensington, Md., on May 12, '87, R. Ridlgway grot one at Gainesville, Va., and on May 18, ' 84 , H. W. Henshaw got one, the first on record for the District of Columbia, $\mathbf{W m}$. Palmer shot one on September 30, '94, and Robert Ridgway shot one on October 18, 'S9, at Laurel" (Richmond).

Melospiza georgiana (584). Swamp Sparrow.

Occasionally noted during winter, and common from September 30 ('94) to November 11 ('94), and again from April 8 ('93, Gray) to April 29 ('94); extreme dates are September 16 ('94) and May 12 ('94, Wholey). At Washington, "from September 28 (90) to the last of October, when they sometimes swarm in suitable places; a few winter, and in April they again become common, the last being noted on May 16 ('88)" (Richmond).

"Resident; though much more abundant during the migrations than at other times. The Swamp Sparrow breeds on the marshes of Tinicum Township, Delaware County, Pa., and in other similar situations, but seems to be rather locally distributed during the breeding season in southern Pennsylvania" (Birds, E. Pa. and N. J., 118).

\section{Passerella iliaca (585). Fox Sparrow.}

Common during migrations, from Octolere 21 ('94) to December 16 ('94), and from February 13 ('92, Gray) to April 23 ('92, Gray), a few occasionally wintering. On November 
5, '93, I saw between 400 and 500 in Dulaney's Valley, one of which gave me a wild burst of song. At Washington, recorded "from October 18 ('94) to April 15 ('94). Two were shot on April 21 at Laurel, by Geo. Marshall" (Richmond); noted at Hagerstown in May, 'S0, and also "a few all winter" (Small).

\section{Pipilo erythrophthalmus (587). Towhee.}

Common summer resident, occasionally wintering. Noted from March \& ('94) to November 13 ('92), and common from April 2 ('93) to October 21 ('92); nests with eggs range from May 13 ('94), to August 28 ('91, Fisher'). Sets are 8 of 3, and 3 of 4 . Six nests were on the ground, the others elevated, the highest being $6 \frac{1}{2}$ feet up in a cedar.

During the severe winter of '92-3, Mr. W. N. Wholey and I watched a flock from December $S$ to February 14, seeing it 3 or 4 times a week. Neither of us could ever count the flock; sometimes there seemed more, sometimes less, but we estimated it to average about 50 birds. There was snow on the ground all this time and the temperature went down as low as $1^{\circ}$, and for over a month the maximum kept below $32^{\circ}$ (Fuhenheit).

In Somerset County they were numerous from November 15 to 21 ('94, Fisher).

At Vale Summit they were common, June 5 to 14 ('95).

\section{Cardinalis cardinalis (593). Cardinal.}

Resident, old birds generally seen in pairs, the young (presumably) going in flocks in fall and winter, occasionally a few pairs of adults may be found quite near each other. Nesting dates range from Nay 3('92, Wholey), a nest ready for eggs, to August 18 ('S3), 3 eggrs. Sets are 1 of 2,17 of 3 , and 1 of 4 .

Habia ludoviciana (595). Rose-breasted Grosbeak.

A migrant, seen at irregular intervals and not to be proenred every year; it has been fairly well noted from April 28 ('93, Resler) to May 20 ('76, Resler) and from September 11 ('so, Resler) to September 25 ('93, Gray). 
"A regular migrant at Washington, not rare, but of" irregular abundance from May 3 ('91 and '92) to May 16 ('S8 and '90) and from August 29 ('ST), when Mr. R. Ridgway shot one at Gainesville, Va., to September 28 ('S9)" (Richmond).

On Dan's Mountain, in Mleghany ('ounty, I found 2 pairs, one located at l'ompey Smash, the other about a mile distant at Lauertown. Morning and evening, from June 5 to 14, '95, both the males could be heard singing. ( )n .June S, I found the nest of the I'ompey Smash pair; it containerl a young bird not 2.4 hours old and 2 infertile eggr. (On the 14th I again visited this nest; on being disturbed the young one scrambled out of the nest and fell to the ground; I replaced it and hope it arrived at maturity, and will live to a green old age.

\section{Guiraca cærulea (597). Blue Grosbeak.}

This large sized edition of the Indigo bird seems to nest more or less regularly in southern Maryland, Washington being about its northern limit, where it is noted as "rather rare, from first week of May to middle of September" (A. C., 68). "During the summer of ' 87 a pair nested twice on my father's farm, about a half-mile east of the District of C'olumbia. On June 24 I took the first nest and 4 egges from the fork of a peach tree, about 7 feet up. . . . In August evidently the same birds nested in a small cedar. I have observed them every season since, but have found no more nests" (A. B. Farnham, Oologist, viii, 219-20).

At Washington "a male was seen on June 30, '89 ; a pair, male and female, were taken by Wm. Palmer on August 15, '92, and several were seen and one shot on September 19, 'S6. At Kensington, Mrd., a nest was found early in .June '95, by J. D. Figgins, and another with 4 egress was found at Lamel about Jume 10, '95, by (Geo. Marshall" (Richmond). ()ne was taken in Howard County, on July 29, '93 (Resler). On August 3, '91, a pair were seen feeling flying young on the Windsor Road, about a half'-mile this side of P'owhattan (Gray 
and $\mathrm{B} \operatorname{logg})$. At Hagerstown "a male with testes as large as peas was shot by A. J. Jones on May 23, '82" (Small).

\section{Passerina cyanea (598). Indigo Bunting.}

Common summer resident; first noted on April 30 ('92, Gray) and common from May 2 ('93) to September 30 ('94); the last was taken on October 5 ('S7, Resler). At Washington, "noted on April 29 ('94, Currie, Preble and Hasbrouck); it was still common on September 30 ('90, '94), while one was found on October 15 ('90); and on December 13 ('87) Mr. M. M. Green shot one, it was 'fat and healthy'" (Richmond).

A nest ready for eggs on May 25 ('90) contained 3 on June 1, and on August 29 ('91); a brood of young left a nest on being disturberl. Sets are 1 of 1, 5 of 2, 17 of 3 and 5 of 4 .

At Vale Summit they were common, June 5 to 14 , '95.

\section{Spiza americana (604). Dickcissel.}

"A summer resident. This bird used to arrive regularly about the first of May, and leave towards the end of September, meanwhile being very abundant. . . . Now, however, the birds seem to have forsaken us, few, if any, having been heard for the past few years" (A. C., 67). "Extremely rare; this bird is said to have been abundant formerly, but it appears to have withdrawn almost entirely from this vicinity. A male, seen by Mr. Henshaw about the last of May, 'S7, was very likely nesting" (C. W. Richmond, Auk, v, 22). "At Jefferson, Maryland, Mr. J. D. Figgins got one on August 4, '90, and 2 more the next day" (Richmond).

The case seems to be paralleled near Baltimore. I have been several times told of its former abundance, and how easily it was taken with bird-lime. The only late item, however, is "on May 7,'92, near Wyndhurst Avenue, on the Baltimore and Lehigh Railroad track, I heard a strange bird song; locating it, I saw a male Black-throated Bunting, it was in plain sight and identification is positive" (Wholey). Specimens were taken by Mr. Resler on May 20, '76, June 10,'76 and October 2, 
'80, at Back River. At that time they were quite common, and no special attention was paid to them.

Family TANAGRIDE-Tanagers.

Piranga erythromelas (608). Scarlet Tanager.

Summer resident; generally dispersed, but local and not very common. Noted from May 4 ('92, Resler) to October 7 ('93, Pleasants). At Washington "from April 25 ('95) to October 7 ('88, W. T. Roberts)" (Richmond).

Nests with eggs are noted from June 2 ('SS, J. H. Fisher, Jr.) to July 18 ('93, Pleasants), while in Howard County three fresh eggs were collected on August 1 ('92, Resler). Sets are 2 of 3 and 3 of 4 .

Only a single pair at Vale Summit, June 8, '95.

\section{Piranga rubra (610). Summer Tanager.}

Summer resident; about as numerous as the last species, noted at Washington from April $2 S$ (') 4, Richmond) and at Baltimore from April 30 ('93, Blogg) to September 12 ('93, Gray). Eggs are recorded from June 7 ('93, Wholey) to July 10 ('93, Bloggs). Sets are 4 of 3 and 1 of 4 .

In '90-1-2, Scarlet Tanagers occupied a piece of open woods back of our house in Dulaney's Valley; in '98, there were no Searlet Tanagers, but several pairs of Summer Tanagers; in '94, no Tanagers appeared; but this year ('95), four or five pairs of both speeies spent the summer, some of them nesting quite close to the house. Both species have been more numerous this year than I have known them before.

Family Hirundinide-Swallows.

\section{Progne subis (611). Purple Martin.}

Common summer resident. First noted in Kent County on March 30 ('95, Fisher), and in Baltinore County f'rom $A$ pril 2 ('93) to October 15 ('93). In spring they are generally first observed at the bird boxes, these they leave as soon as the young 
are able to go with them, the latest date being August 27 ('94), when only one pair was left. On July 28 ('95), 6 were in a small dead tree in Dulaney's Valley; as there were only one adult male, this family presumably had started to migrate. In this same tree on August 12 ('94), at 10.40 A. M., I saw 18 (3 adult males) all sound asleep, with their heads under their wings. On being flushed by a knock on the tree they flew round for a few minutes and returning, settled themselves again, evidently played out from a long migration flight. At Bay Ridge, towards dusk, on August 18 ('95), quite a large number flew south in an uneven but regular column.

On May 18 ('92) a box held 8 nests in various stages of construction, from just started to ready for eggs, and on May 29 ('94) another had 21, ranging from just started to having the complete set of' 5 eggs, while as late as July 9 ('95, Henninghouse) 3 fresh eggs were taken. Sets are 3 of 5 . Usually nesting in the boxes put up for them, on June 12, '94, I found nests with young under the eaves of cottages at Ocean City. At Washington they formerly nested in the tops of the columns of the Treasury Building, now "in crevices of the Post Office Department Building and the Masonic Temple" (Richmond). At Bay Ridge, on June 28, '93, several pairs were nesting in the hoods of electric lamps (Gray). At Cumberland on June 4, '95, I found them in the electric lamps, and also in cornices of buildings.

\section{Petrochelidon lunifrons (612). Cliff Swallow.}

Summer resident, extremely local and not common; but a colony may locate their nests under the eaves anywhere, оссирy them any number of summers, then, without apparent cause, leave, sometimes coming back after one or more years. First seen on April 16 ('93), when 26 were flying in a loose flock; the last were also seen in a loose flock on September 3 ('93). At Washington, September 12 (A. C., 52). Nesting dates range from June 7 ('S2), five fresh eggs, to July 23 ('93), when young birds were still in nests. On July 22 ('93), however, 
I saw quite a number on the telegraph wires, young and old, ready to go south. Sets are 1 of 1,1 of 2,2 of 3,1 of 4,1 of 5 .

Chelidon erythrogaster (613). Barn Swallow.

This, our swallow proper, is an exceedingly numerous :ummer resident, there being scarcely a harn or out-building that has not its swallow nests on the rafters. First noted on April 3 ('s0, Resler), on the 15th ('93) they were numerous, remaining so until September 20 ('90, Resler). Birds congregated on the telegraph wires, ready to migrate, have been seen as carly as July 5 ('94). Nesting dates range from Nay 29 ('81), slightly incubated eggs, to August ? (93), small young birds. Sets are 1 of 1,4 of 3,6 of 4, and 10 of 5 . At Washington they were noted Mareh 30 (90), and nests with 1 and 2 egges were found on May 16 ('86, Richmond). At Hagerstown on March 20, 's0 (Small).

A small colony was at Vale Summit June 5 to 14, '95.

Tachycineta bicolor (614). Tree Swallow.

Sparingly distributed along the shores of tidewater Maryland in summer, this species may be seen anywhere during migrations, when it is abundant. Noted from March 30 (')2, Resler) to October 17 ('94, Resler); quite a large number were flying south in a loose, desultory mamer over Ferry Bar on $A$ ugust 12 ('95). At Washington it is recorded from "March 30 ('90), to October 14 ('94), when there must have been a wave of them, as Wm. Palmer got one and saw several at Kensington, Mdd.; Geo. Marshall saw one at Laurel, Mrl., and R. Ridgway saw 2 or 3 at Gainesville, Va." (Richmond). On October 14, '94, there was quite a large number in Dulaney's Valley. Several were seen at Harper's Ferry, April 8, 'S7, by F. L. Washburn (Birds Vas., 77). At Hagerstown in September, '82, and May, '83 (Small). Nests with eggs are noted from May 12 ('94, Fisher) to July 3 ('93, Blogrg). Sets are 1 of 4 , 2 of 5 , and 1 of 6 . 


\section{Clivicola riparia (616). Bank Swallow.}

Comnon summer resident. Quite a number were at Loch Raven on April 14 ('95), but they were down the necks earlier, for on April 19 ('95, Fisher), at Gunpowder, a new hole had been dug about a foot deep and two others a few inches. The last birds were noted September 12 ('85, Resler). At W'ashington, from April 25 ('S6, '94) to September 15 ('90, Richmond). On July 17, '91, a large number, possibly between 3000 and 4000 were on a ducking blind at the muth of Back River; they kept up an incessant twitter and were evidently ready to leave for their winter home. May 12 ('91), slightly incubated eggs, and July 17 ('92), young birds, are extreme nesting dates. Sets are 3 of 2, 2 of 3,3 of 4,3 of 5, 2 of 6 , and 2 of 7 .

Stelgidopteryx serripennis (617). Rough-winged Swallow.

Summer resident, but not as numerous as the Bank Swallow. Observed at Washington April 8 ('92, R. Ridgway, Auk, ix, 307 ), at Baltimore, April 19 ('79, Resler); the last recorded at Washington was shot on September 3 ('94, Richmond). Sets of eggs, noted from May 13 ('S3) to June 15 ('S1), are 2 of 4, 1 of 5,1 of 6 , and 1 of 7 . "Numbers of these birds breed along the Fotomac River in crevices of the rock; . . . a nest of 7 eggs found during June, '87, contained six eggs of this species and one of the Barn Swallow" (C. W. Richinond, Auk, v. 23). At Hagerstown, Small says ('SO-'81), "the Bank and Rough-winged Swallows are about equally common."

\section{Family Axpelid E-Waxwings.}

\section{Ampelis cedrorum (619). Cedar Waxwing.}

Resident, roving in flocks all the year, from which, in their leisurely mamner, a pair will detach themselves and go to housekeeping, generally in July or August. Eggs are noted from June 17 ('92, Blogg) to August 21 ('92). At Vale Summit a nest had 5 fresh eggs on June 11 ('95). Sets are 1 of 3 , 2 of 4 , and 4 of 5 . 
Family LanIId 2 -Shrikes.

Lanius borealis (621). Northern Shrike.

Probably a regular, though rare winter visitor. On Octoher 26,'s7, one was taken on P'atapseo Marsh (Resler); December 2, '94, one in Dulaney's Valley; January 10,'93, one at Bay View (1. Wolle); February 11, '92, one at Powhattan (Gray); February 19, '93, one was seen in Dulaney's Valley, and on February 25, '93, one was seen just west of the city (Gray). At Washington, "one was shot on December 26, 's7; another on Jamuary 10, ') 1, and one on February 10, ' 46 . Numbers of others have been taken" (Richmond).

\section{Lanius Ludovicianus (622). Loggerhead Shrike.}

A common resident in the south $A$ tlantic States, wandering north in winter. Near Baltimore single birds are numerously recorded from Auguat 26 ('92, Blogg) to April 2:) ('93, Gray), and near Washington f'rom "Augunt 11 ('s!) to April 6 (-); dozens have been reported, mostly, however, in midwinter" (Richmond). At Hagerstown "only seen a few times. One was seen in May eating a large beetle under the spruce in our yard, and one was noted in December, '80" (Small).

\section{Family Vireonide-Vireos.}

Vireo ólivaceus (624). Red-eyed Vireo.

Very common summer resident. First noted on April 23 ('9:); a week later they were numerous everywhere, remaining so until Oetober 6 ('9t), the latest date being of a single bird on October 11 (98). At Washington "from April 22 ('91) to October 14 ('94, Palmer and Figgins), specimens were taken -one on October 17, '90; four on October 30, '94 (Palmer and Figgins), and one on November 11, 'SS (Figrgins)" (Richmond).

Nests with eggs range from June 8 ('85) to July 31 ('93), while young birds not long out of the nest and still being fed by the parents were seen on reptember 1 (92). Sets are 11 of 2,29 of 3 and 3 of 4 . 
Vireo philadelphicus (626). Philidelphia Vireo.

"Not very common in the Atlantic States" (Key, 332). "A regular but rather rare spring and fall migrant, arriving here late in April or early in May; after the 20th of May it is seldom seen in P'emnsylvania until it migrates southward in September" (Birds Pa., 264). "A very rare migrant;" 10 specimens are recorded between September 11 ('S0) and October 6 ('91) (Birds E. Pa. and N. J., 126). "One taken on the Virginia side of the Potomac near Washington, on May 17, 's8" (Wm. Palmer, Auk, vi, 74). "Wm. Palmer also got one or two additional ones, and J. D). Figgins shot one on September 16, '94, at Kensington, Md." (Richmond).

Vireo gilvus (627). Warbling Vireo.

Of local distribution, in some parts of Maryland it is a summer resident, lut near Baltimore I have only found it as a migrant. On May 5, '82 (Resler), one was taken, the only spring note. In ' 94 I found it quite numerous in Druid Hill Park on August 21, 22 and 24, and again on Oetober 4 and 6, but not between times. At Washington it is "a summer resident, not very common, from $\Lambda_{\text {pril }} 28$ ('S9) to September 10." Mr. Figgins found it very common at Kiensington, Md., on August 23, '94 (Richmond).

At St. Michuel's, Talbot C'ounty, on June 15, '94, a pair were very lively in a shade tree. At Hagerstown, "the Redeye and Warbling Vireos are to be heard all through the long summer days; they both breed in town, but the Warbling is decidedly the most common, staying with us from the first week of May to October" (Small). In Cumberland, on Jume 4, '95, quite a number were in the shade trees.

\section{Vireo flavifrons (628). Yellow-throated Vireo.}

Regular, but not very common summer resident, more numerous during migrations. Noted from April 13 ('90, Pleasants) to October 6 ('94). In Dorchester County they were numerous, 
and specimens were taken on April 6, 9:3 (R. C. Walter:). "A common summer resident at Washington, f'rom April 20 to the middle of September. II $\mathrm{m}$. I'almer found a nest with 3 small young on June 1, 'ot" (Richmoml). On May 27 (')?, Blogg) a nest held :) half-incubated egge; on June 15) (998, Fisher) one contained young birds, and on .June 19) ('92, Wholey) one had 4 eggs ready to hatch.

\section{Vireo solitarius (629). Blue-headed Vireo.}

A regular migrant, not common. Noted from April 19) (1): Resler and Wholey) to May 11 (93, Pleasints), and from September 26 ('94, Resler) to October 22 ('92, Gray). During spring single birds are usually seen; in fall, small parties of 4 or 5. At Washington "not uncommon in migrations, April 1:" ('88, Hasbrouck) to May 10 ('S5) and October S ('SS) to October 26 ('90)" (Richmond). At Hagerstown "a f'ew were seen in the spring migrations; they hard a decided partiality for some climbing roses, and were very unsuspicious" (Small).

\section{Vireo noveboracensis (631). White-eyed Vireo.}

Common summer resident from April 22 ('91, Resler) to September 23 ('94). At Washington "from April 12 ('g() to October 12 ('90)" (Richmond). Nesting notes range from May" 27 ('95, Fisher), 2 fresh eggs, to August 6 ('9:) $), 2$ birds about two-thirds grown. Sets are 1 of 2,3 of 3 and 1 of 4 .

While the nest is usually placed near water, or in a swampy place, on July t, '94, I found a nest containing young nearly ready to fly, on top of a high, dry hill, fully $\frac{1}{y}$ of a mile f'rom the nearest spring.

\section{Family MNiotiltide-Wood Warblers.}

Mniotilta varia (636). Black and White Warbler.

First noted on April 15 ('93, Gray;'95, Resler), and numerous on April 23 ('92, '93). Gradually thimning out as the loreeding season comes on, it is again abundant from early in August to 
September 16 (94), after which it is occasionally noted until October 9 ('S9, Resler). At Washington "from April S ('SS) to October 18 ('92)" (Richmond). The nest, being placed on the ground, is seldom found; those noted are: May 16 ('91, Blogg), 3 eggs nearly hatched; June 1 ('S9, Blogg), 4 birds and a rotten egg; July 4 ('92), 3 birds a f'ew days old.

On Dan's Mountain they were very common. On June 5, 95, I found a nest with 5 nearly fresh eggs; it was placed in a crevice, about 4 feet up the perpendicular face of Dan's Rock, on the summit of the mountain.

\section{Protonotaria citrea (637). Prothonotary Warbler.}

"Rare or casual on the Atlantic const north of Georgia" (Manual, 4S4). One was seen on May 2, '61, near Washington (A. C., 42.) "On May 17, '88, near Laurel, Mr. P. L. Jouy and I noticed a Prothonotary Warbler, and later, when we were in company with Geo. Marshall, another (or possibly the same one) was seen, but we failed to secure either" (R. Ridgway). On August 25 '95, I saw 2 in Dulaney's Valley; they were fussing with one another and allowed of quite close approach. “On May 11,'94, an adult male was taken at Mit. Vernon, Va., by E. M. Hasbrouck" (Richmond), and Captain Crumb has taken one at Cobb's Island (letter to W. H. Fisher).

Helmitherus vermivorus (639). Worm-eating Warbler.

Sparingly resident, from May 2 ('90, Gray) to September 10 ('92, Resler). At Washington "from $\Lambda_{\text {pril }} 29$ ('SS, Hasbrouck), it remains throughout most of September" (Richmond); at Hagerstown to September 19 ('79, Small). On Jume 7 ('S5) a nest held 4 eggs slightly incubated; on .June 25 ('93) 4 birds were nearly ready to fly; on July 2 (93, Wholey) a nest was ready for eggs; on July 4 ('91) adults were feeding young barely out of the nest, and on August 15 ('91, Gray), a pair were leading full grown young. At Washington it has been found nesting along Rock Creek, where on May 31, 'S5, a nest 
with 6 well incubated eggs was found, and on Jume 14,'S5, and June 5, 's7, nests with 5 young about half grown were also found (C. W. Richmond, Auk, v, 23-4).

Helminthophila pinus (641). Blue-winged Warbler.

This species, fairly numerous in migrations, from May 5 (95) to May 16 ('93, Wholey), and from August 18 ('91, Gray) to September 21 (94), has been found as a regular, but rare summer resident along Gwymn's Falls, between Calverton and Franklin (Blogg and (iray), where in '92, on Jume 11 and 14, young birds just out of the nest were noted, and on the latter date 3 were caught. On July 5, another brood had just left a nest. In '93, on May 20, a nest was half built; on the 27 th it contained one erge, but later it was deserted. On June 13 a nest was found containing 3 birds just hatched and an infertile egg; on July 1, another had 4 birds under a week old and an infertile egg, and on July 12, another nest was found with young birds. On May 29, '94, a nest was found with four fresh eggs.

On June 15, '95 (Fisher) a pair was seen at Mt. Washington where five days later I noted a pair feeding young, and on July 10,'91 (Fisher), one bird secured from a flock of 5 or 6 at Ruxton indieates its nesting there. "Geo. Marshall and others have foumd it breeding at Laurel, Md., and at Washington, where it is rare as a breeding bird, a nest was found by Mr. H. H. Birney carly in June, 'so, with 4 eggss about to hatch" (Richmond).

Helminthophila leucobronchialis (-). Brewster's Warbler.

The identity of this bird is not very clear, but it is supposed to be a hybrid ; it has been found from Virginia to Connecticut, and as far west as Michigan. On May 15, 'S5, one was taken near Fort Myer, Alexandria ('ounty, Va., by Wm. Palmer (Auk, ii, 304), and a rery typical male was taken at Beltsville on May 1, '95, by A. H. Thayer (C. W. Richmond, Auk, xii, 307). 
Helminthophila chrysoptera (642). Golden-winged Warbler.

Uncommon migrant; on May 7, '92 (Pleasants), one was taken and several others seen near 'Towson. On May 29, '92 (Wholey), one at Waverly, and on September 5, '93 (Gray), another near Franklintown. At Laurel a female was taken on May S, '94, by Geo. Marshall. At Washington "one was seen on May 2, '90, and specimens were taken on May 4, '88 (Hasbrouck), and '90 (Figgins); on August 8, '89; on August 11, 'S9 (Palmer); and a pair on August 17, '\$9. There are numerous other records" (Richmond). On Dan's Mountain I noted one on June 10, '95.

\section{Helmin thophila ruficapilla (645). Nashville Warbler.}

Regular, though not common migrant. On May 6, '93, and 7, '92 (Pleasants), single birds were taken near Towson. On May 11, '02 (Wholey), 3 birds were shot out of about 20 at Waverly, where on the 12 th they were still more numerous; at the same place they were very numerous on May 14, '93, but 3 days later only one was noted. One was taken at Towson on September 18, '93 (Pleasants). At Washington "specimens were taken on May 1, '89 (R. Ridgway); May 3, '88 (A. K. Fisher); May 13, 'S2 (H. M. Smith); September 5, '82 (H. M. Smith); September 16, '94 (Figgins); and September 18, '90, etc." (Richmond).

Helminthophila celata (646). Orange-crowned Warbler.

"Migrates sparingly east of the Alleghauies" (Manual, 488). ()n Octoher 12, '89, one was taken at Munson Hill, Va., a few miles from Washington, by Dr. A. K. Fisher (Auk, vii, 96), and (aptain Crumb shot one at Cobb's Island in the fall of ' 87 (letter to W. II. Fisher). " "Wm. Palmer shot one on October 14, '94, at Kensington, Md. This is the latest warbler to arrive, all eastern North Ameriean dates are very late, compared with those of the other wirblers. In spring it should be looked for in March" (Richmond). 
Helminthophila peregrina (6t7). Temmessee Warbler.

Irregular fall migrant, has not yet been noted in spring. Specimens have been taken near Baltimore on September 18 ('93, Gray) and September 20 ('9:), Pleasants). "At Washington, on August 31 ('90, Figgins; W. L. Richmoud); September $2 S$ ('82, Palmer'; '90); September 29 ('\$9, Figrins); October ? ('94, Palmer); October 11 ('61, T. ('. Smith); ()etober 12 ('90); November 30 ('89), and others are recorded. Some seasons it is not rare in the tall, rank growth of weeds on the P'otomac Flats" (Richmond).

Compsothlypis americana (648). Parula Warbler.

A common migrant, this species also spends the summer with us in numbers, where it finds the hanging moss (I $T_{\text {snea }}$ ), and occasionally elsewhere. First noted near Baltinore on April 25 ('91, Gray), it was common on May 4 ('93, Fisher) and began to thin out by May 17 ('92, Wholey). The first fall movement was noted on August 21 ('94), and it was numerous from September 12 ('90, Gray) to October 8 ('92, Gray), the latest date being October 17 ('s8, Resler). At Washington it "was first noted on $A_{\text {pril }} 19$ ('91), and common on $A$ pril 28 (' 89 ); the last was recorded on October 16 ('87)" (Richmond).

During summer, noted near Baltimore on June 3 ('91, Resler), June 8 and 30 ('93, Wholey), July 4 and 14 ('9:' Gray) and July 29 and August 5 ('92, Resler). At Washington on June 10 ('86, Richmond).

On the Isle of Wight, Worcester County, a few miles north of Ocean City, Md., on June 8, '9t, I saw a pril f'eeding four flying young; this prompted further investigation, and on the 12th I found them very numerous, in the 4 hour I spent there, noting at least 50 pairs of adults with young, calch lrood licepling separate.

On Dan's Mountain I noted a female on June 5, '95, the only one seen there. 
Dendroica tigrina (650). Cape May Warbler.

I have only records of 2 specimens taken near Baltimore, one on October 21 ('93, Wholey) at Wayerly, the other on October 22 ('90, Resler) at Back River. "Not by any means rare in the District of Columbia, some seasons quite common; quite a number of specimens are on record between May $S$ ('S9, $R$. Ridgway) and May 16 ('89, R. Ridgway). On August 4, '92 (E. J. Brown), one was taken and they are again numerously recorded from August 25 ('90, Figrins) to October 7 ('82, H. M. Smith), while on December 16,'88 (Figgins), an adult male was shot; it was in company with $D$. coronate and was in good health and spirits when found" (Richmond).

Dendroica æstiva (652). Yellow Warbler.

Scattered everywhere in migrations, and locally common during summer. On April 6 ('93, R. C. Watters) quite a number were seen and one shot in Dorchester County. April 15 ('95, Wm. Palmer), at Washington; April 21 ('83 Small), at Hagerstown, and April 24 ('S9, Resler), are first dates. They soon become numerous, but thin ont by May 11 ('92). In the fall I have never seen them so numerous as they are in spring, generally only a single bird being seen at a time, the last on October 2 ('94). Nests with eggs are recorded from May 15 ('95, Gray) to June 16 ('95). Sets are 3 of 3,1 of 4 , and 1 of 5 . Common at Vale Summit, June 5-14, '95.

\section{Dendroica cærulescens (654). Black-throated}

Blue Warbler.

An abundant migrant, noted as numerous from April 30 ('93) to May 15 ('92); the last were seen on May 2S ('94), when a pair, male and female, spent the day at Waverly, Baltimore City. August 27 ('89, Resler) notes the first return in the fall and they were numerous f'rom August 31 ('93 Gray) to October 18 ('93), when an enormous number were in a small patch of woods. At Washington, "from April 27 ('SS, Hasbrouck) to May 30 's3 , and from August 31 ('90) to October 19 ('92)" (Richmond). 


\section{Dendroica coronata (655). Myrtle Warbler.}

Abundant migrant, some occasionally wintering with us. On September 7, '94, a single bird was seen in Druid Hill Park. On September 30 ('94) the migration commenced and they are numerously noted to November 12 ('?2, Gray) ; after which they were recorded on November 24 ('92), December 28 ('91, Gray) and January 28 ('93, Gray), becoming common again on February 4 ('93, Gray) and remaining so until May 5 ('95), the latest date being May 19 ('93, Resler). At Washington, it is "a common winter resident from September 30 ('90; '94) to May 20 ('88)" (Richmond). At Hagerstown, "plentiful in November and February, many spent the winter of ' $79-80$, while other winters only a f'ew were seen. In 'S3 they remained in considerable numbers until May 6" (Small).

During the latter part of June, '79, a male, female and 3 young about half grown were observed near Havre-de-Grace. The male was perfectly healthy, but the female had a healed up broken wing and was only able to flutter a short distance, which accounts for their staying to breed (Ludwig Kumlein, B. N. O. C., v. 182.)

\section{Dendroica maculosa (657). Magnolia Warbler.}

Abundant migrant; noted from May 4 ('93, Fisher) to June 3 ('94, Gray), and from August 22 ('94), to October 5 ('87, Resler). At Washington "from April 22 ('91) to May 30 ('91), and from August 16 ('89) to October 5 ('90)" (Richmond). "The nest has been found in Somerset County, Pa., where I am informed they breed regularly" (Birds Pa., 283).

\section{Dendroica cærulea (658), Cerulean Warbler.}

Rare east of the Alleghanies. On July 14, '93, an adult male and 2 young birds were taken; the male had been heard singing for a week previously (J. H.Pleasants, Jr., Auk, x, 372). On May 5, '88, a male was taken at Rock Creek, and on May 11, '90, a female on the Virginia side of the Potomac near Washington (E. M. Hasbrouck, Auk, v, 323 and vii, 291). 
At Hagerstown it was noted as a rare transient and questioned as a summer resident (Small), while Dr. H. D. Mearns gives it as "a rare summer visitant" in Somerset County Pa., (Birds Pa., 269 and 284).

Dendroica pensylvanica (659). Chestnut-sided Warbler.

A common migrant from April 29 ('93, Gray) to May 25 ('92, Resler), and from August 15 ('90, Pleasants) to September 25 ('93, Gray). On October 18, '93, a remarkably large number of this species were observed. They, with other species, fairly swarmed in an S-acre piece of woods; my note book says: "The ground was covered with Towhees and Snowbirds, the bushes were full of White-throats, Song Sparrows and Snowbirds, while the trees were filled with Black-throated Blue, Black-throated Green, and Chestnut-sided Warblers, Golden and Ruby-crowned Ringlets, Robins and Blue Jays,-evidently a first-class bird-wave."

At Washington they are recorded from "April 28 to May 30 ('91), and from August 10 ('s9 ; '94, Figgins) to September 29 ('89)' (Richmond).

On July 4, '93 (Wholey), a pair were taken near the Blue Mountain House, and on July 24, '93 (Gray), a pair with "worms" in their bills were seen within 100 yards of High Rock, showing that they breed on the Blue Ridge. On Dan's Mountain they were fairly common from. June 5 to 14 , '95; on the 9 th I collected a nest with 4 eggs about half incubated.

Dendroica castanea (660). Bay-breasted Warbler.

Migrant, not common; specimens have been taken as follows: May 16 ('91, Blogg) at Franklintown, May 21 ('93, Wholey) at Waverly, May 24 ('90, Pleasants) at Towson, and May 28 ('93, Wholey) at Waverly; September 20 ('93, Gray) at Calverton, September 21 ('93, Pleasants) at Towson, and September 28 ('89, Resler) at Back River. 
At Washington " a late arrival in spring of irregular alumdance, usually uncommon; from May 10 to 27 ('8s; s) shot by Wm. Palmer), and from August 29 ('S7, R. Ridgwaly) tu October 19.('s8, R. Ridgway). On September 22, 24t and 2!), 's9, they were common at Great Falls, MId." (Richmond).

\section{Dendroica striata (661). Black-poll Warbler.}

Common nigrant from May 4 ('92, Resler) to May 28 ('s7, Resler; '93, Wholey), and from September 24 ('St, Resler) to October 18 ('90, Resler). At Sandy Springs, to June 3 (Stabler). At Washington " numerous from May 1 to .June 1 (' 88 , '89, and '90, Figgins; '91), and from September 1 ('s? and '94, Figgins) to October 20 ('S9) One was seen on June :', 'S9; one was shot on June 4, '58, (Coues), and one was heard singring on June 12, '94 (Brown)” (Richmond). “On July 30, '93, an adult male was shot at Washington (E. J. Brown, Auk, xi, 79).

Dendroica blackburniæ (662). Blackburnian Warbler.

Common migrant from May 2 ('93, A. Wolle) to May 1!) ('92, Resler), and from August 30 ('93, Gray) to October 1:) ('S3, Resler). At Washington "as early as August 19 ('94, Brown)" (Richmond). On July 28, '92, in Howard County, a young male was taken by A. Resler (Transactions of the Maryland Academy of Sciences, 1892, 20:3). On June 10, 95, on Dan's Mountain, while watching a pair of Louisiana Water Thrushes, a male flew close to me and commenced bathing.

Dendroica dominica (663). Yellow-throated Warbler:

"Southern Atlantic States, north regularly to Maryland (near seacost)" (Manual, 503). On May 12, '95, at Fairwiew, a fishing shore on Rock Creek, Anne Arrundel ('ounty, and 9 miles from Baltimore, Mr. W. H. Fisher noted 3 birds of this species; two were together in the woods, the third was in a tree at the boat-landing. 
" $\Lambda$ t Washington it is not common; specimens have been taken as follows: July 15, '94, 3 (Brown and Palmer); July 20, '90, 3 or 4 (Figgins and Richmond); July 27, '90, 1; July 28, 'S9, 4 (Figgins and Richmond); July.29, '94, 1 (Brown and Palmer); August 1, '89, 5; August 1, '94, 4 (Figgins); August 5, '89, 1; September 4, '90, 1 seen. In '93, at Johnson's Gully, near Marshall Hall, Md., where it undoubtedly breeds, Palmer and Hasbrouck found it on June 1 and 11, July 22 and August 10. On Smith's Island, Va., about May 24, '94, I saw one with a 'worm' in its mouth, evidently feeding young" (Richmond).

Dendroica virens (667). Black-throated Green Warbler.

Common migrant from April 21 ('93, Blogg) to Nay 15 ('92), and from August 30 ('90, Resler) to October 22 ('90, l'leasants). On October 18, '93, they were remarkably numerous in the bird wave already noted. At Washington from April 22 ('SS, M. M. Green) to May 19 ('S8; '95, Palmer), and from August 26 ('S9, Figgins, at Jefferson, Md.) to October 21 " (Richmond). On June 14, '95, on Dan's Mountain, a pair were feeding flying young.

Dendroica kirtlandi (670). Kirtland's Warbler.

Migrates through southeastern United States and Mississippi Valley; sunmer home unknown, winters in the Bahamas. "Wm. Palmer shot one on September 25, 'S7, near Fort Myer, Va. (about one-quarter mile from the Potomac River)" (Richmond).

\section{Dendroica vigorsii (671). Pine Warbler.}

Fairly numerous during migrations, this species, local in its distribution, spends the summer with us in limited numbers. Numerously noted from April 9 ('90, Resler) to April 25 ('S5, Resler), and from August 3 ('93, Resler) to October 22 ('92, Blogg). On Jume 29, '93 (Resler), one was taken at Back River, and on July 2, '93, another in Dulaney's Valley. At 
Washington "noted from March 24 ('89, Figgins) to ()ctoloce 25 ; it is a rare summer resident but swarms at times in the fall. Figgins found them in immense numbers on August 31, '90, and shot 18" (Richmond).

In Dorchester County, on April 6, '9:' (IR. (: Watters), several were seen and one taken. In Worcenter County, on June 12 , '94, en the mainland, about a mile from Ocean City, I watched a male for about an hour in hopes of locating the nest which evidently was close at hand, but I did not find it.

\section{Dendroica palmarum (672). Palm Warbler.}

"Oceasional (or casual) during migrations east of the Alleghauies" (Manual, 517). The following specimens have been taken near Washington, where it is "probably a regular, though rare, migrant." April 22,' S5, Roslyn, Alexandria County, Va.; April 29, 'SS, Roslyn, (C. W. Richmond); May b and May 11, '89, Laurel, Prince George County, Md. (R. Ridgway); May 11, '90, Riverdale, Prince George County, Mcl. (C! W. Richmond); May 11, '81, Soldiers' Home, District of Columbia (L. M. McCormick); September 18, '87, Potomac Landing, Alexandria County, Va.; September 22, '9:, Four Mill Run, Alexandria County, Va. (J. E. Brown); October 4, '(31, Ballston, Alexandria County, Va. (Wm. P’almer, Auk, xi, 3:3:3).

Dendroica palmarum hypochrysea $(672 a)$, Yellow Palm

\section{Warbler.}

A regular migrant; common, usually appearing in small flocks, though of ten single birds are seen, from I pril 4 (9:;, Gray) to April 29 ('91, Resler), and from September 12 ('95), Hoen) to October 22 ('93). At Washington "from March :31 ('S9) to April 29, and in the fall they were still common on October 19 ('90, Figgins)" (Richmond). "One year they were very common at Hagerstown in October, swarming everywhere, some even coming in at the windows" (Small). 


\section{Dendroica discolor (673). Prairie Warbler.}

A summer resident, but so decidedy local that until its special haunts are discovered its presence is not suspected. These are usually of limited extent, but quite a number are known near Baltimore, a few pairs breeding at cach. Noted from April 22 ('91, Resler) to September 5 ('83, Resler). On June 4 ('90, J. II. Fisher, Jr.) a nest held slightly incubated eggs, and on July 16 (93) young birds left a nest on being disturbed. Sets are 3 of 3 , and 1 of 4 . "Common at Washington from April 19 ('91) to September. Mr. Figgins found a nest with 4 eggs on Nay 14, '91, and another with 3 on May 30, 's8', (Richmond).

\section{Seiurus aurocapillus (674). Oven-bird.}

Common summer resident; first noted on April 9 ('93), and numerous from April 21 ('93, Resler) to September 16 ('94); the last was recorded on October 18 ('90, Resler). Extreme nesting dates are May 24 ('91, J. H. Fisher, Jr.), fresh eggs, and August 6 ('93), young just out of the nest. Sets are 2 of 3,7 of 4, and 1 of 5 . At Washington "to October 17, '90; on May 20, '88, a nest with 4 eggs was found" (Richmond).

Seiurus noveboracensis (675). Water-Thrush.

Common migrant from April 27 ('92, Resler) to May 25 ('93, Resler), and from August 29 ('94, Resler) to October 16 ('92, Wholey). At Washington "from April 22 ('94, Wm. Palmer) to May 25. On July 21 ('94, Figgins) one was found that had killed itself by flying against telegraph wires, and it is numerously recorded from that on until September" (Richmond).

Seiurus noveboracensis notabilis $(675 a)$. Grinnell's WaterThrush.

A western species. Two specimens taken in Virginia, near Washington, May 11, '79, and May 5, '85, are in the collection of Mr. W. Palmer (Auk, v, 148). Another was captured 
by Dr. A. K. Fisher, August 5, '\$6, not far from the Long Bridge, on the Virginia side of the Putomace" (Birds Vas., '\$5-6.)

Seiurus motacilla (676). Louisiana Water-Thrush.

Common during migrations. This species probably spends the summer with us in greater numbers than is generally supposed. Noted from April 's ('93, (iray) to September 24 ('92, Blogg). On June 13 and 22, '93 (Gray), a pair were seen feeding young near Franklintown. At Washington "a nest and 5 badly incubated eggs were obtained on Pincy Branch, May 25,'88, by G. E. Mitchell. Wm. Palmer got a fully fledged young bird about June 14, '91" (Richmond). On June 10, '95, I found two pairs on Dan's Mountain, where, no doubt, they were nesting.

\section{Geothlypis formosa (677). Kentucky Warbler.}

Summer resident, not rare round Baltimore; a pair usually occupying each marshy spring head in heary wools. Noted from April 29 ('92, Blogg) to September S (95); nesting dates range from June 18 ('9:3), young just hatched, to July 27 ('95), young still in nest. Sets are 1 of 3 and 4 of 4 . At Washington "not very common, May 3 to Septemher 5 . On June 15, '79, Mr. H. W. Henshaw found a nest with 4 eggs somewhat incubated" (Richmond). At Johnson's Gtully, Mad., on May 30, '92, a nest with 5 egges was found, and on June 6, '29, another with 4 eggs, both slightly incubated (E. M. Hasbronck, Auk, x, 92).

\section{Geothlypis agilis (678). Connecticut Warbler.}

A rare migrant. I have no spring dates, but specimens have been taken from September 20 ('93, Pleasants) to Octoher 1 ('90, Resler). At Washington "very rare in spring. Mr. I. MeCormick shot one at Falls Church, Va., in May, '79, and Wm. Palmer got a female on May 23, '91. It is fairly common in fall, and has been taken from dugust $2 S$ ('S6, Dr. A. K. Fisher) to October 12 ('90), when two were taken on the Potomac Flats and another seen" (Richmond). 
Geothlypis philadelphia (679). Mourning Warbler.

Rare migrant; near Baltimore single birds have been recorded as follows: May 28, '91, Towson (Pleasants), shot; May 26, '77, Back River (Resler), shot; June 3, '93, Franklin Road (Gray), seen; August 24, '87, Patapsco Marsh (Resler), shot; August 30, '93, Back River (Resler), shot ; September 1, '90, Franklin Road (Blogg), seen; September 13, '79, Bay View (Resler), shot; September 18, 93, Franklin Road (Gray), seen ; September 26, '94, Back River (Resler), shot; September 30, '93, Dulaney's Valley (Wholey), shot; October 5, '87, Patapsco Marsh (Resler), shot.

On August 17, '94, an immature female was taken at Laurel, by Mr. Geo. Marshall. At Washington "very rare from the middle to the end of May and from August to October 1, '94, when Wm. Palmer got an immature female" (Richmond).

Geothlypis trichas (681). Maryland Yellow-throat.

Our most abundant summer warbler; first noted on April 20 ('91, Resler), it soon becomes common and remains so until October 6 ('95), the last being recorded on October 19 ('92, Resler). The nests of this species, as of all ground buildings birds, are difficult to find, so I have but few items; extremes are May 24 ('92,Wholey), a nest ready for eggs, and August 13 ('93), when young leave a nest. Sets are 1 of 3 , and 2 of 4 . At Washington "abundant from April 15 ('91, R. Ridgway) to October 21 ('95, Palmer and Matthews)" (Richmond). Not very common on Dan's Mountain, June 5-14, '95.

\section{Icteria virens (683). Yellow-breasted Chat.}

Common summer resident, from April 30 ('92, Gray); they leave early and but few are seen after August 6 ('93), though single birds have been noted until August 30 ('93, Gray). At Washington "from April 29 ('74, Palmer, Hasbrouck and Preble; 'S8,Hasbrouck) to September" (Richmond). It is given to September 20 in Penusylvania (Birds Pa., 299). Eggs 
are noted from May 22 ('\$9, J. H. Fisher, Jr.) to July 12 ('91). Sets are 9 of 3,2 of 4, and 1 of 5 . A few pairs were on I)an's Mountain; a nest contained 3 eggs on June 14, '95.

Sylvania mitrata (684). Hooded Warbler.

A rare migrant; near Baltimore specimens have been taken : May 3, '90, and 10, '84 (Resler); May 15, '92 (Wholey); September 8, '93 (Gray); September 20, '90 (Resler), and one was seen on September 22, '95. Possibly it breeds in limited numbers in Howard County, for on August 4, '94, near Botterill P. O., 14 miles southwest of Baltimore, Mr. A. Resler collected a young bird not long out of the nest, and four days later a pair of adults, male and female. At Washington "a rare migrant, may breed. Specimens have been taken from May 1 ('SS, Hasbrouck) to the end of the month; and from August 19 ('94, Figgins), at Kinsington, to September 15 ('90)" (Richmond).

Sylvania pusilla (685). Wilson's Warbler.

A fairly common migrant from May 6 ('93, Gray) to May 26 ('95), and from September 11 ('92, Gray) to September 23 ('93, Wholey). At Washington "rither common from May 8 to May 23 ('91), and from August 31 ('90) to the middle of' September" (Richmond).

Sylvania canadensis (686). Canadian Warbler.

Common migrant from May 4 ('95, Fisher) to May 29 ('94, Resler), and from August 7 ('S9, Resler) to September 15 ('90, Gray). At Washington "from May 5 ('94, Hasbrouck) to May 27, and from August 7 ('87) to September 24 ('S9)", (Richmond). On Dan's Mountain, on June 10, '95, I eame across a male singing, and later a pair with young in the nest.

Setophaga ruticilla (687). American Redstart.

Common migrant from April 25 ('91, Blogg) to May 24 ('93, Wholey), and from August 24 ('91) to Octolier 15 ('93); most of the notes, after the middle of September, record imma- 
ture birds. It is also fairly common, though local, during the summer. A pair were seen mating on May 15 ('92), and young birds out of the nest are noted from June 3 to July 18 ('93, Gray). On June 20, '93, Mr. W. H. Fisher and I found them very numerous at Mount Washington. In a walk of about three-fourths of a mile we noted 9 pairs feerling young, and no doubt there were others we did not see. Sets are 3 of 3 . At Washington it is "a conmon migrant, first noted on $\Lambda_{\text {pril }} 19$, '91. A few breed. Hasbrouck found a nest with 4 eggs nearly hatched on May 21, '88" (Richmond). On Dan's Mountain, June 5 to 14 , '95, they were very numerous; their numbers about equalled that of all other birds seen there. On the 9th young birds left a nest before I could count them.

\section{Family Motacilidide-Pipits.}

\section{Anthus pensilvanicus (697). American Pipit.}

Common in flocks from October 13 ('95) to November 19 ('94), and from February 11 ('94) to May 13 ('92); occasionally some winter with us. At Washington "from October 15 ('90) to Nay 4 ('S9); more numerous in October, November and March and April than in midwinter. They were common until November 30, 90 " (Richmond).

On November 12, '93, I found a large flock in Dulaney's Valley; some were ruming and presumably feeding on pasture, others on a part that had been newly turned up, while the greater number were either bathing in a shallow puddle or dressing their feathers in an adjoining tree, being perched on the branches from the ground up to the top, fully 50 feet from the ground; they, however, were more at home on the fence rails or on the ground.

Family Troglodytide-Thrashers, Wrens, etc.

Mimus polyglottos (703). Mockingbird.

Resident in the southern counties of Maryland and regular in summer as far north as Kent and Ame Arundel Counties. In 
the balance of the state it can only be called a stragghler. On May 2, '93 (Fisher), one was at Glyndon. On June 7 and 14, 'S5, one was singing in great style at Fork. On September 17, '93, two were fussing in a tree in Dulaney's Valley, where Mr. Thomas Peere informs me a pair "used" until a few years ago, and also that another pair regularly spent the summer just across the ridge in Long Green Valley, until about the same year. In the spring of ' 82 (Pleasants) two nests with eggs were found near Towson.

On June 28, '93 (Blogg), a nest with young about a week old was found at Bay Ridge, Anne Arundel County. In Queen Anne County, on May 30, '92, a nest was ready for eggs, and on May 27 and 31, and June 1 and 2, nests were found with 3 young birds in each. At St. Michael's, Tialbot County, 4 fresh eggs were found on Jume 13, '94.

\section{Galeoscoptes carolinensis (704). Catbird.}

Common summer resident from April 25 ('92, Gray) to October 22 ('90, Resler). One was noted in Inlaney's Talley on December 24 ('94, W. L'Allemand), and on April 2 ('93) two very noisy birds spent the day at $W$ averly. At $W$ ashington "from April 16 ('94, R. Ridgway) to October" Wm. I'almer has taken a specimen in December, and on January 13, 'S9, I found the remains of one that had been killed by some hird of prey" (Richmond). On May 4 ('92) a pair were building, and eggs are recorded from May 16 ('91) to August 16 ('91). Sets are 1 of 1,6 of 2,31 of 3,15 of 4 , and 2 of 5 . At Vale Summit, I only saw 3 in 10 days.

The following is the result of observations made on a nest built in a veranda at Tacoma, D. C. After the nest had been completed 24 hours, the first egg was laid on May 11, '93, at $10.35 \mathrm{~A}$. M., the second at $9.40 \mathrm{~A}$. M., the third at 9.15 A. M., and the fourth at 10.15 A. M. on successive days. For the first 4 days she sat upon them only at irregular intervals, but this habit soon changed after that time. On Niay 25 there were no birds hatched at dark, but on the morning of the 
26th 3 young were in the nest, the other hatehed the next night. At 6.45 P. M. on June 5 they all left the nest together (R. W. Shufeldt, Auk, x, 303-4).

Harporhynchus rufus (705). Brown Thrasher.

Common summer resident, from April 19 ('94) to September 21 ('94); extreme dates are April 7 ('90, Resler) and November 5 ('93). "At Laurel, on April 2 ('S8, R. Ridgway), two were seen. At Washington from April 6 ('SS) to November 13 ('87)" (Richmond). May 21 ('93), a nest with birds about one-half grown, and August 6 ('93), another with birds only 3 or 4 days old, are extreme nesting dates. Sets are 2 of 2,4 of 3,5 of 4 , and 1 of 5 . Usually nesting in a brier tangle or thick bush; on May 29, ' $\$ 1$, one was placed on the broken-off' top of an appletree stub about 7 feet high. On July 26, '91, one was on the 4th rail of a worm fence, and on June 24, '91, another was on the ground under a potato vine. At Vale Summit they were not common; on June 7 a nest held 4 fresh eggs.

\section{Thryothorus ludovicianus (718). Carolina Wren.}

Common resident, occasionally vying with the House Wren in semi-domesticity. On April 8 ('94) a nest was nearly finished, and on May 2 (90) a brood of young left a nest, while as late as August 10 ('93) slightly incubated eggs were taken. Sets are 1 of 3,1 of 4,2 of 5 , and 2 of 6 .

On April 26, '91, I was shown a nest containing 3 fresh eggs placed behind an ornament in the corner of a friend's parlor; later, I was told that either five or six young were raised there. At Vale Summit one bird was seen on June 13, '95.

\section{Thryothorus bewickii (719). Bewick's Wren.}

A rare bird east of the Alleghanies. Single birds are recorded at Washington as follows: April 5, '92 (R. Ridgway), seen; April 6, 's3 (Wm. Palmer), shot; April 8, 'sS (M. M. Green), shot; April 10,'S2 (Wm. Palmer), shot; April 22, '88 (M. M. Green), seen ; November 24, 'S9 (J. D. Figgins), shot; Decem- 
ber 22,'90 (C. W. Richmond), seen (Roht. Rirlgway, Auk, ix, 307, and Richmond). Possibly it is common in summer in parts of western Marylind. On July 4, ’ (Wholey), about one hundred yards from (2uir-Auk, on the Blue Rirlge Mountain, a nest of this species was found in a hollow logr ; in it were 4 young, which Huttered out, leaving 2 infertile eggs. On the same day a specimen was sceured near the Blue Mountain House. On August 2,'93 (Gray), one was observed near Hagrerstown. On June 9 and 14, '95, I noted this species at Vale Summit, and on the 11th a pair were seen with a brood of young.

\section{Troglodytes aëdon (721). House Wren.}

A common summer resident. This semi-rlomesticated, wholly independent and irrepressibly impudent little bird has been noted from April 12 ('95, Fisher) to Octuber 10 ('93), on which latter date a number were seen at Bright Lights, near North Point. P'osibly they may arrive earlicr than above given, for on April 27 ('9:3) a nest was about one-half' built, and 3 days later another was nearly ready for eggs. The earliest date, however, I have found eggs is May 19 ('95), the latest July 17 ('92), and on August 26 ('94) young birds barely out of the nest were seen. Sets are 2 of 3,3 of 4,7 of 5,4 of 6 , and 2 of 7 .

This species of ten pre-empts the nests of other birds, the Downy Woodpecker being the most usual victim. On May 26, '94, a Carolina Wren's nest, which I had watched being built, held one egg; on June 3 a House IVren was found it it, and having added 5 of her own was sitting on them, all 6 being slightly incubated. As a rule, when the House Wren jumps a claim it modifies things to suit itself, but in this case it made no changes, the nest being exactly as the Carolina ITren had built it.

Troglodytes hiemalis (722). Winter Wren.

Common winter resident from September 26 ('94, Resler) to May 7 ('93, Blogg, Fisher and F. C. K..). At Washington 
"from September 27 ('S9, R. Ridgway) to April 29 ('s8)" (Richmond). While a few come round the farm buildings, others may be found in dry upland woods, but to see any number in the course of a day's walk, our wooded watercourses must be followed, where they will usually be found among the roots that hang from the washed banks, the individuals being about one-half a mile apart. On November 27, '92, Mr. W. N. Wholey and I heard one sing in Dulaney's Valley.

Cistothorus stellaris (724). Short-billed Marsh Wren.

Very rare. On April 18, '79, a specimen was presented to the Maryland Acadeny of Sciences by Mr. W. S. Clayton. Presumably it was taken in the vicinity of Baltimore. At Washington E. M. Hasbronck has taken two specimens; one, a female, on May 9, '90 (Auk, vii, 289), the other on May 3, '93 (Richmond). "Rare migrant, and in southern New Jersey occasional (regular?) winter resident" (Birds E. Fa. and N. J., 144 ; Auk, ix, 204).

\section{Cistothorus palustris (725). Long-billed Marsh Wren.}

Common summer resident in the marshes of tidewater Maryland; it probably also winters in limited numbers in southern Maryland, as Messrs. S. N. Rhoads and Witmer Stone found it "tolerably common in cattail swamps" at Cape May City, N. J., January 26 to 29, '92, (Auk, ix. 204). Noted near Baltimore from A pril $2 S$ ('94, Wholey) to October 14 ('91, Resler), and at Washington to October 19 ('90, Richmond). Nests with eggs range from June 3 ('90) to August 7 ('90), on which latter date 3 other nests were ready for eggs, so presumably they nest later. Sets are 1 of 2,1 of 3,9 of 4,6 of 5 , and 1 of 6 . At Hagerstown one was observed "for a few days in spring in the yard" (Small).

\section{Family CerThIID E-Creepers.}

Certhia familiaris americana (726). Brown Creeper.

Fairly common during winter from September 26 ('94, Resler) to May $S$ ('75, Resler). "One was taken at Washington 
on September 22, '55, by Dr. Cones" (Richmond). On September 27 ('94, Fisher) one was seen in a tree at the corner of Park Avenue and Madison Street. At Hagerstown "f rom October to May" (Small).

Family PARIDE-Nuthatches and Tits.

Sitta carolinensis (727). White-breasted Nuthatch.

Common resident, but usually seen singly or in pairs. On March 31 ('94, Blogg) a pair were found building, and on April 7 the nest contained 1 egg. On July 26 ('94) young just out of the nest were observed.

On June 11, '95, a single bird wats noted on Dan's Mountain, and on July 6 ('95, Tylor), a pair were feeding young at Deer Park.

Sitta canadensis (728). Red-breasted Nuthatch.

Common during some winters, this species is either wanting, or very rare during others. During the severe winter of '92-3, they were quite numerous round Baltinore. Tsually found singly, at times several may he seen fairly close together. September 11 ('so, Resler) and May 6 ('93, Cray), are extreme dates; on this last day they were quite numerous and a number of specimens were taken. At Washington to May 10 (Richmond), and at Hagerstown to May 4 (Small).

Sitta pusilla (729). Brown-headed Nuthatch.

Apparently a regular summer resident in southern Maryland. On May 28, 92, in Queen Ame County, I found a pair building a nest in a small hole in a dead pine stub, and later in the day, about three-quarters of a mile ristant, I came across another pair. In Worcester County on the mainland, about a mile from Ocean City, on June 8, '94, I found a single bird.

"It is common at St. George's Island and P'iney P'oint, Mi., near the mouth of the Potomac, and on Smith's Island, Va. Between Cape (harles and Brighton it was noted in small numbers and is probably common" (Richmond). 


\section{Parus bicolor (731). Tufted Titmouse.}

Common resident. On $\Lambda$ pril 10 ('92) a nest was ready for eggs, and on August 4 ('94) young not long out of the nest, keeping in a close bunch and still being fed, were seen. Sets are 1 of 5 and 1 of 8 . "Their notes are heard loudest on clear winter days, and at Hagerstown they are locally called "Storm Bird" (Small). On Dan's Mountain I noted single birds on June 11 and 12, '95.

\section{Parus atricapillus (735). Chickadee.}

Irregular winter visitant, sometimes common in cold seasons ('92-3 for instance), when the majority of the following species leave us. Noted from October 15 ('92; '93) to March 21 ('95).

"Mr. Henry Marshall has taken it at Laurel" (A. C., 37). "This bird was very abundant about Washington during March and April, '85. . . O Owing probably to the severe winter they were driven south, returning about the middle of March; the first specimens were taken March 15, and others were taken every week until April 19, when 6 were shot and many others seen. The weather during April was fine and warm, and the birds were singing and apparently quite at home. But few $P$. carolinensis were seen until the last week of April, showing that they too had been driven much further south" (Wm. Palmer, Auk, ii, 304). Noted at Hagerstown as "common during the winter of ' $80-81$ "; none, however, were seen the previous or the two succeding seasons (Small).

Parus carolinensis (736). Carolina Chickadee.

Common resident. On April 23 ('93) a nest held 2 fresh eggs, and on July 23 ('93) young, not long out of the nest, were seen. Sets are 2 of 2,1 of 3,2 of 4,1 of 5,1 of 6 , and 2 of 7.

At Hagerstown "resident, but scarce in summer" (Small). On Dan's Mountain, June 6, '95, young were in the nest of the only pair seen. 
Family SylviIDE-Kinglets and Gnateatchers.

Regulus satrapa (718). Golden-crowned Kinglet.

Winter resident; very common during some seasons ('92-3, for instance) and comparatively rare other's. 'They are, however, most numerous during migrations, thinning ont about the end of October and getting numerous enrly in March. Fxtreme dates are September 30) ('93, Gray) and April 22 ('93, Gray). $\Lambda$ t Washington "one was taken on April 27 ('88, Hasbrouck)" (Richmond), and at Hagerstown it was noted as "staying until May" (Small).

Regulus calendula (749). Ruby-crowned Kinglet.

A common migrant; possibly a few winter with us during mild seasons. Noted from September 26 ('94, Resler) to Novenber 5 ('92, Gray), and from April 2 ('S7, Resler) to May 7 ('93). At Hagerstown, a "common migrant in March and April, October and November; plentiful in fall, but scarce in spring" (Small). At Washington "from September 25 ('S7) to early in November, and from April 8 ('SS) to May 10 ('91). Specimens have been taken in winter: two on December 1 ('S9, C. W. Richmond; A. K. Fisher), one on December 15, '89, and 2 others seen, and 1 on Februaly 9 (91, Figgins)" (Richmond). "On December ह̇, 92, I saw and positively identified a single Ruby-crowned Kinglet in the grounds of the Department of Agrieulture, and also saw what was presumably the same individual on .Jannary 5, 6 and 14 , '93, this period covoring some of the most severe weather ever known here" (L. IV. Clyde Todd, Auk, x, 206).

\section{Polioptila cærulea (751). Blue-gray Gnateatcher.}

Fairly common during summer in restricted localities, from April 1 ('93, Gray) to September 14 ('9:), Ciray). It Irashington "from April 5 to September; one was shot on November 23, '90" (Richmond). On May 7 ('93), a nest was nearly finished; Nay $1 \pm$ ('):', Blogge) and June 4 ('95, Fisher) are extremes for eggs. Sets are 7 of 4 . 
On June 12, '94, on the Isle of Wight, near Ocean City, I saw two pairs with young just out of the nests.

Family TurdIDE-Thrushes, Bluebirds, ete.

Turdus mustelinus (755). Wood Thrush.

Common resident from April 29 ('93 ; '94) to October 2 ('95). Extreme dates are April 13 ('92) and October 15 ('93). At Washington "several were seen on April 19, '91, and they were common the next day" (Richmond). At Vale Summit they were fairly numerous, June 5 to 14, '95.

Eggs are recorded from May 18 ('91; '95) to July 28 ('95). Sets are 1 of 1,18 of 2,30 of 3 , and 16 of 4 .

\section{Turdus fuscescens (756). Wilson's Thrusla.}

Fairly common migrant, from April 23 ('93, Fisher) to Nay 30 ('92, Blogg) and from August 29 ('93, Gray) to October 6 ('94). At Washington "from April 26 to May 2S, and from August 18 ('89, Figgins) to the end of September" (Richmond). At Hagerstown it was noted in Oetober ('79, Small). On July 6, '95 (Tylor), a pair were feeting young at Deer Park.

Turdus aliciæ (757). Gray-cheeked Thrush.

Regular, but not very common migrant, from May 12 ('92, Wholey) to May 30 ('92, Resler), and from September 12 ('94, Resler) to October 16 ('92, Wholey). At Washington "l'ather' ciminon from May 10 to June 5, and from September 10 to October 10" (Richmond).

Turdus aliciæ bicknelli (757a). Bicknell's Thrush.

Apparently a rare migrant. "At Laurel Mr. Robert Ridgway shot an adult male on May 14, '8S, and 4 days later an adult female; near Washington on October 3, '85, I secured an adult male" (Richmond). 
Turdus ustulatus swainsonii (758a). Olive-backed Thrush.

Common migrant from April 30 ('92, Wholey) to May 28 ('93, Wholey), and from September 16 (92, Pleasants) to October 13 ('94). At Washington "until Oct. 20, '90" (Richmond).

Turdus aonalaschkæ pallasii (759b). Hermit Thrush.

A common migrant from October 4 ('94) to November 28 ('91, Resler), and from March 23 ('S9, Resler; 94, Fisher) to May 21 ('92, Gray). It also stays with us sparingly during winter, single birds being taken as follows: December 24,'92 (Wholey); January 1, '92 (Wholey); January 8, '87 (Resler); January 17, '92 (Wholey); Jamuary 20, '93 (Gray); January 27, '95 (F. C. K.), 1 scen; January 29, '80 (Resler), 1 seen; February 6, '76 (Resler), 1 seen ; February 22, '92 (Gray), 1 seen; and March 5, '90 (Resler). In Somerset County they were common from November 13 to 22, '94 (Fisher). On July 9, '90, an adult female was shot in Howard County, about fifteen miles southwest of Baltimore City, by A. Resler (Forest and Stream, xxxv, 11).

\section{Merula migratoria (761). American Robin.}

Resident, abundant in flocks during the migrations, it is commonly scattered over the country during summer, and a few scattered flocks as a rule winter with us in the uplands north of Baltimore, while down the "necks" they are more numerous, and in southern Maryland large flocks are characteristic of the winter season. Eggs are noted from May 5 ('95) to July 30 ('81). Sets are 7 of 3 and 10 of 4 . At Hagerstown eggs were also noted on May 5 ('82, Small). Not numerous at Vale Summit, June 5 to 14 , '95.

\section{Sialia sialis (766). Bluebird.}

Common resident. On March 18 ('94) a nest was ready for eggs, and birds were in another on August 12 ('94). Sets are 2 of 2,3 of 3,5 of 4 , and 7 of 5 . 
In the fall and winter they of ten go in flocks of 5 or 6 , to about 20 , but generally they will be seen iu pairs. On Januiry 16, '95, Bluebirds were seen at Cumberland, where the river's and creeks had been frozen over from December 25 (Howarl Shriver, Maryland State Weather Service, Report of February, '95). On June 11, '95, a brood of flying young were noted at Vale Summit.

The latter part of the winter of '94-5 was remarkable for its severity all over North America, and the birds were thinned out in great numbers. Perhaps from being more familiarly known than other small birds, the almost complete absence of Bluebirds and Phobes caused considerable comment. The blizzard of early February completely covered Maryland with 2 feet or more of snow, and travel was stopped for about 10 days by the drifts. Bluebirds had been numerous around Baltimore up to this time, and 2 were still alive on February 10. Later in the season a number of Screech Owl holes were found more or less filled with Bluebird feathers, and the owls were absent. Only a very few seattered Bluebirds were noted during summer and fall until November 3, when my note book says, "scattered everywhere over Dulaney's Valley in pairs, evidently a migration flight"; on November 9 a flock of about 20 was seen. At Washington " 21 dead birds were found by Robt. Ridgway in a bird box on his grounds, where they had been frozen by the blizzard which almost exterminated them in this part of the country" (Richmond). 


\section{ADDENDA.}

Larus atricille (i) \&), Laughing Gull. About 100 were below Fort MLEIIenry on April 23,3 , '95, and about a dozen were in the lower harbor on Oetober 24, '95.

IIydrochelidon nigre smrinamensis (\%'). "The Black Tern at Washington, D. C. September 1S, 93 I shot 13 Black Terns. Previous to this I an aware of only one recorded instance of its ocenrene, one heing foumd dend feptember 1S, '82. Edward J. Biown" (Auk, xi, 73).

Phalarocorax dilophus (1.2()), Donble-crested Cormoraut. 7 ('ormorants, presumably of this species, were seen at ()cean City on September 23, '94 (Tylor).

Rallus virginianus (212), Virginia Rail. Occasional in winter. One was shot near Baltimore, late in December, '79 (Resler), and a male, in full plumage and in fine condition, was taken in a terrapin trap) on January 2(), ' 1, near Easton ("Sinkboat", Forest and Stream, xxxvi, 44).

Gullinago delicutu ( $\therefore ;())$, Wilson's Snipe. On December 29, '94, a f'emale was shot at Wrestover, Somerset ('o., by Mr. M. T. Sudler.

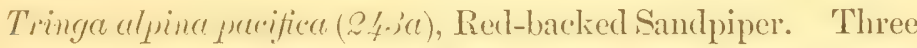
were at Lock Raven on September 29, '95.

Totanus melanolencus (254), Greater Yellow-legs. On November 13, '75, one was shot at Back River (Resler).

Totanus flavipes (255), Yellow-legs. Numerous at Loch Raven from September 22 to October 13, '95.

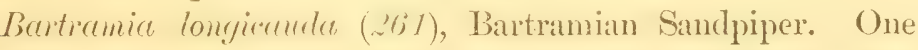
was shot on September 1:), '95, near Relay, by Mr. (․ Gamble Lowndes.

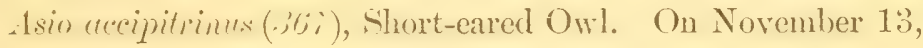
'95 one was shot at Bear' Creek, Baltimore Co. 
Coccyzus americanus (387), Yellow-billed C'uckoo. One was seen at Pikesville on October 27, '95 (Fisher).

Carpodacus purpureus (51\%), Purple Finch. Should be recorded to May 21 ('92 Gray); not to May 31 ('93 Fisher).

Calcarius lapponicus (536), Lapland Longspur. "'The blizzard drove half a dozen of these birds into Baltimore City, where on February 4, 5, and 10, '95, they were seen in company with English Sparrows feeding in the bed of North Avenue ncar Caroline St. They allowed of quite close approach" (Resler). Ammodicamus maritimus (550), Suaside Sparrow. "A specimen was collected some 9 or 10 years ago, on Miller's Island, Baltimore Co., by the late Mr. Wolle, Sr., at whose house I had the opportunity to examine the bird before it was mounted " (Resler).

ERRATA.

Page 255, line 24, for Cantter read Cantler.

Page 269, line 19, for nivialis read nivalis.

Page 270, line 19, for Hutchin's read Hutchins's.

Page 274, line 1, for Ardella read Ardetta.

Page 275, line 29, for corulea read crrulea.

Page 277, line 24, for vialaceus read violaceus.

Page 281, line 5, for light house read life-saving station.

Page 292, line 14, for Black-billed read Black-bellicd.

Page 301, line 27, for (399) read (339).

Page 318, line 31, for (622a) read (466a),

November 15, 1895. 


\section{INDEX.}

SCIENTIFIC, POPULAR, AND LOCAL MARYLAND NAMES.

ACANTHIS IINARIA, 528.

Accipiter atricapillus, 331. cooperi, 333.

velox, 332.

Actitis macularia, 263.

Egialitis meloda, 277.

m. circumcincta, $277 \mathrm{c}$.

semipalmata, 274.

vocifera, 273.

wilsonia, 280 .

Agelaius phoeniceus, 198 .

Aix spousa, 144.

Alca torda, 32.

Alle alle, 31.

Ammodramus caudacutus, 519 .

c. nelsoni, $549 x$.

c. subvirgatus, $549 b$.

henslowii, 547 .

maritimus, 550 .

princeps, 541.

sandwichensis savauna, $542 a$.

savannarum passerinus, 546.

Ampelis cedrorum, 619 .

Anas americana, 137.

boschas, 132.

corolinensis, 139 .

crecca, [138.

discors, 140

obscura 133

penelope, 136.

strepera, 135

Anhinga, 118

anhinga, 118.

Anser albifrons gambeli, 171a.

Anthus pensilvanicus, 697 .

Antrostomus carolinensis, 416 . vociferus, 417.

Aquila chrysaëtos, 349 .

Archibuteo lagopus sancti-johannis, $347 \alpha$.

Ardea candidissima. 197.

cærulea, 200

egretta, 196.

herodias, 194.

tricolor ruficollis, 199.

virescens, 201.

Ardetta exilis, 191.

Arenaria interpres, 283.

Asio accipitrinus, 367.

wilsonianus, 366 .

Assemblyman, 165.

Auk, Razor-billed, 32.

Aythya affinis, 149 .

americana, 146.

collaris, 150

marila nearctica, 148 .

vallisneria, 147 .

BALD-CROWN, 137.

Bald-face, 137.

Baldpate, 137.
Bartramia Iongicauda, 261.

Bay Blackhead, 148.

Bay Muscovy, 163, 165, 166.

Beach Bird, 248.

Bee-martin, 444.

Beetle-head, 270.

Bittern, A. 190.

Least, 191.

Blackbird, Cow, 495.

Crow, 511.

Marsh, 498.

Red-winged, 498.

Rusty, 509.

Swamp, 498.

Yellow-headed, 497.

Blackhead 148, 149, 150 ,

Black Logcock, 405 .

Blue-bill, 148, 149, 167.

Bluebird, 766.

Blue-twing, 140 .

Bobolink, 494.

Bob-twhite, 289.

Bonasa umbellus, 300 .

Booby, 163, 165, 166, 368, 375.

Botaurus lentiginosus, 190.

Brant, 173.

Black, 174.

Branta bernicla, 173

canadensis, 172.

c. hutchinsii, $172 \alpha$.

vigricans, 174.

Brass-eye, 151.

Broad-bill, 142.

Bubo virginianus, 375 .

Buffle-head, 153.

Bull-bat, 420 .

Bull-head, 270.

Bunting, Bay-winged, 540.

Black-throated, 601 .

Indigo, 598.

Snow, 534.

Butcher-bird, 621, 622 .

Buteo borealis, 337 .

latissimus, 343.

lineatus, 339.

Butter-ball, 153.

Buzzard, Turkey, 325.

CALCARIUS LAPPONICUS, 536.

Calico-back 283.

Calidris arenaria, 248.

Campephilus principalis, 392.

Camptolaimus labradorius, 156.

Canary, Fly, 652.

Wild, 529, 652 .

Canvasback, 147.

Cardinal, 593.

Cardinalis cardinalis, 593.

Carpodacus purpureus, 517.

Catbird, 704. 
Catharista atrata, 326.

Cathartes aura, 325 .

Cedar-bird, 619.

-lark, 619.

Waxwing, 619.

Ceophlcus pileatus, 405.

Cepphus grylle, 27.

Certhia familiaris americana, 726 .

Ceryle alcyon, 390 .

Chretura pelagica, 423.

Charadrius dominicus, 272. squatarola, 270 .

Charitonetta albeola, 153.

Chat, 683.

Yellow-breasted, 683.

Chebec, 467.

Chelidon erythrogaster, 613.

Chen hyperborea nivalis, $169 a$.

Cherry-bird, 619 .

Chewink, 587.

Chickadee, 735 .

Carolina, 736

Chip, 560.

Chip-bird, 560

Chippy, 560.

Winter, 559

Chondestes grammacus, 552.

Chordeiles virginianus, 420.

Chuck-will's-widow, 416 .

Circus hudsonius, 331

Cistothorus palustris, 725 . stellaris, 724.

Clangula hyemalis, 154.

Clivicola riparia, 616 .

Coccyzus americanus, 387.

erythrophthalmus, 388.

Colaptes auratus, 412.

Colinus virginianus, 289.

Columbigallina passerina terrestris, 320 Colymbus auritus, 3 .

holbcellii, 2.

Compsothlypis americana, 648 .

Contopus borealis, 459 .

virens, 461.

Conurus carolinensis, 382.

Coot, 167.

A., 221.

Sea, 163, 165, 166

White-winged, 165 .

Cormorant, 119.

Double-crested, 120.

Corvus americanus, 488.

corax principalis, $486 a$.

ossifragus, 490.

Coturnix communis, (after 289).

Cowbird, 495.

Crane, 194.

Blue, 194.

Sandhill, 206.

White, 196, 197, (200 young).

Creek Blackhead, 149

Redhead, 150 .

Creeper, Black and White, 636 . Brown, 726.

Crossbill, A, 521 .

Red, 521 .

White-winged, 522 .

Crow, A., 488.

Fish, 490 .

Rain, 387, 388 .

Sea, 286.

Crow-bill, 221.

Crymophilus fulicarius, 222

Cuckoo, Black-billed, 388. Yellow-billed, 387.

Curlew, Eskimo, 266.

Hudsonian, $265^{\circ}$.

Jack, 265.
Curlew, Long-billed, 264.

Short-billed, 265.

Sickle-billed, 264.

Cyanocitta cristata, 477.

DABCHICK, 6.

Dafila acuta, 143.

Dendroica xstiva, 652.

blackburniæ, 662 .

cærulea, 658 .

cærulescens, 654 .

castanea, 660 .

coronata, 655 .

discolor, 673 .

dominica, 663 .

kirtlandi, 670 .

maculosa, 657.

palmarum, 672 .

p. hypochrysea, $672 \alpha$.

pensylvanica, 659 .

striata, 661 .

tigrina, 650 .

vigorsii, 671 .

virens, 667.

Dickcissel, 604.

Dipper, 6, 153.

Diver, Great Northern, 7.

Hell, 6.

Dog-bird, 202.

Dolichonyx oryzivorus, 494.

Dove, 316 .

Carolina, 316.

Ground, 320.

Mourning, 316.

Sea, 34 .

Dovekie, 34.

Dowitcher, 231.

Long-billed, 232.

Dryobates borealis, 395 .

pubescens, 394.

villosus, 393.

Duck, Acorn, 144.

Assemblyman, 165 .

Bald-crown, 137.

Bald-face, 137.

Bald pate, 137.

Bay Blackhead, 148.

Bay Muscovey, 163, 165, 166.

Big Blackhead, 148.

Black, 133

Blackhead, 148, 149, 150, 151.

Bluebill, 148, 149, 167.

Blue-wing, 140.

Brass-eye, 151.

Broad-bill, 142.

Buffle-head, 153.

Butter-ball, 153.

Canvasback, 147

Channel, 165.

Creek Blackhead, 149

Redhead, 150 .

Crow, 221.

Crow-bill, 221

Dipper, 153.

Dusky, 133.

Eider, A, 160.

King, 162 .

Fish, 129, 130

Flock, 148.

Gadwall, 135.

Golden-eye, A., 151.

Barrow's, 152.

Gray, 132, 135.

Gray Mallard, 132, 135.

Green-head, 132

Green-winged Teal, 139.

Hairy-crown, 130.

Heavy-tailed, 167. 
Duck,.Jingler, 151.

Labrador, 156.

Lesser Scaup, 149.

Little Blackhead, 149

Long-tailed, 15.

Mallard, 132, 133.

Marsh, 133.

Old-squaw, 151

Partridge, 139.

Pintail, 143.

Raft, 148.

Redhead, 146.

Ring-billed, 150.

Blackhead, 150 .

Ring-necked, 150.

Ruddy, 167.

Scaup, A., 148.

Scoter, A., 163.

Surf, 166.

White-winged, 165

Shovel-bill. 142.

Shoveller, 142

Shuffler, 148.

Spoon-bill, 142

Sprigtail, 143.

Steel-head, 167.

Stiff-tail, 167.

Summer, 144.

Surf, 163, 165, 166

Teal, European, [138].

Tree, 144

Whiffler, 151

Whistler, 151

Widgeon, European, 136.

Wood, 144 .

EAGLE, BALD, 352.

Black, 352.

Golden, 349

Gray, 352.

Spotted, 352.

Vhite-headed, 352 .

Ectopistes migratorius, 315.

Egret, A., 196

Eider, A., 160.

King, 162.

Elanoides forficatus, 327.

Empidonax acadicus, 465.

flaviventris, 463.

minimus, 467 .

traillii alnorum, $466 a$.

virescens, 465 .

Ereunetes occidentalis, 247.

pusillus, 246.

Erisnatura rubida, 167.

Falco columbarius, 357.

peregrinus anatum, 356.

sparverius, 360 .

Finch, Grass, 540.

Lark, 552.

Pine, 533.

Purple, 517.

Fisherman, 129, 130, 131

Hairy-crowned, 130.

Pied, 129.

Flicker, 412.

Flock Duck, 148.

Flocking Fowl, 148.

Flood Gull, 80.

Flycatcher, Acadian, 465 .

Crested, 452

Least, 467 .

Olive-sided, 459.

Scissor-tailed, 443.

Traill's, 466a.

Yellow-bellied, 463.

Fly-up-the-Creek, 201.
French'Mocking Bird, $\{705$.

Fulica americana, 221.

GADWALL, 135.

Galeoscoptes carolinensis, 704.

Gallinago delicata, 230.

Gallinula galeata, 219.

Gallinule, Florida, 219.

Purple, 218.

Gannet, 117.

Gelochelidon nilotica, 63.

Geothlypis agilis, 678 .

formosa, 677 .

philadelphia, 679 .

trichas, 681 .

Glaucionetta clangula americana, 151.

islandica, 152.

Gnatcatcher, Blue-gray, 751.

Godwit, Hudsonian, 251.

Marbled, 249.

Golden-eye, A., 151.

Barrow's, 152.

Goldfinch, A., 529.

Goosander, 129.

Goose, Canada, 172.

Greater Snow, 169a.

Hutchins's, $172 \alpha$.

Nigger, 119, 120.

White-fronted, A., 1710

Wild, 172.

Goshawk, A., 334.

Grackle, Boat-tailed, 513 .

Bronzed, $511 b$.

Purple, 511

Rusty, 509.

Grass Finch, 540.

Grayback, 231.

Gray Duck, 132, 135

Mallard, 132, 135 .

Widgeon, 143.

Grebe, Holbœll's, 2.

Horned, 3

Pied-billed, 6.

Green-head, 132.

Green-wing, 139.

Grosbeak, Blue, 597.

Cardinal, 593 .

Pine, 515.

Rose-breasted, 595 .

Ground Robin, 587.

Dove, 320 .

Grouse, Ruffed, 300 .

Grus mexicana, 206.

Guara alba, 184.

Guillemot, Black, 27.

Guiraca cærulea. 597

Gull, Black-headed, 58.

Bonaparte's, 60 .

Flood, 80.

Great Black-backed, 47.

Herring, A., 51a.

Iceland, 43.

Kittiwake, 40.

(Kumlien's, 45, see 43.)

Laughing, 58 .

Razor-billed, 80 .

Ring-billed, 54 .

HABIA LUDOVICIANA, 595.

Hrematopus palliatus, 286.

Hairy crown, 131.

Haliaetus leucocephalus, 352.

Harporhynchus rufus, 705 .

Hawk, Bird, 332, 357, 360.

Black, $347 \alpha$.

Blue, 331.

Broad-winged, 343 .

Chicken, 333, 337, 339, 343. 
Hawk, Cooper's, 333.

Duck, 356 .

Fish, 364 .

Hen, 337, 339, 343.

Long-tailed Chicken, 333.

Marsh, 331.

Partridge, $332,357$.

Pigeon, 357 .

Red-shouldered, 339

Red-tailed, 337.

Rock, 356.

Rough-legged, A., $317 \alpha$.

Sharp-shinned, 332.

Snowbird, 360.

Sparrow, A., 360.

Heavy-tailed Duck, 167.

Hell-diver, 6, 153.

Helminthophila celata, 616 .

chrysoptera, 642.

leucobronchialis, (after 641).

peregrina, 647.

pinus, 641 .

ruficapilla, 645 .

Helmitherus vermivorus, 639 .

Heron, Great Blue, 191.

Green, 201.

Little Blue, 200.

Little Green, 201.

Louisiana, 199.

Night, Black-crowned, 202.

Yellow-crowned, 203.

Snowy, 197.

Himantopus mexicanus, 226.

Hookumpake, 228

Hummingbird, Ruby-throated, 428.

Hydrochelidon nigra surinamensis, 77.

IBIS, GLossy, 186.

White, 184

Wood, 188.

Icteria virens, 683 .

Icterus galbula, 507

spurius, 506 .

Indian Hen, 190, 405.

Indigo Bird, 598.

Ionornis martinica, 218.

JACKDAW, 513.

Jaeger, Long-tailed, 38.

Parasitic, 37.

Pomarine, 36.

Jay, 477.

Blue, 477.

Jingler, 151.

Jowink, 587.

Junco, Shufeldt's, $567 b$.

Slate-colored, 567.

Junco hyemalis, 567 .

b. shufeldti, $567 b$.

KILDEE, 273.

Killdeer, 273.

Kingbird, 444

Arkansas, 447

Kingfisher, Belted, 390.

King Forester, 405 .

Kinglet, Golden-crowned, 748.

Ruby-crowned, 749 .

Kite, Swallow-tailed, 327.

Kittiwake, 40.

Knot, 234 .

LANIUS BOREALIS, 621.

ludovicianus, 622 .

Lark, 501.

Cedar, 619.

Field, 501 .
Lark, Horned, 474.

Meadow, 501 .

Prairie Horned, $474 b$.

Shore, 474.

Sky, 474 .

Wood, 674.

Larus argentatus smithsonianus, $51 \alpha$.

atricilla, 58

delawarensis, 54.

(kumlieni, 45 , see 43 .)

leucopterus, 43.

marinus, 47.

philadelphia, 60 .

Lettuce bird, 529 .

Limosa fedoa, 249.

hremastica, 251.

Little Black-head, 149

Striker, 74.

Longspur, Lapland, 536.

Loon, 7.

Red-throated, 11

Lophodytes cucullatus, 131.

Loxia curvirostra minor, 521 .

leucoptera, 522 .

MACRORHAMPHUS GRISEUS, 231. scolopaceus, 232.

Mallard, 132, 133.

Black, 133.

Gray, 132, 135 .

Marsh, 133.

Marsh-hen, Fresh-water, 208. Salt-water, 211.

Marsh Robin, 587.

Martin, 611.

Bee-, 444.

Purple, 611.

Maryland Yellow-throat, 681.

Meadowlark, 501.

Megascops asio, 373.

Melanerpes carolinus, 409. erythrocephalus, 406 .

Meleagris gallopavo, 310 .

Melospiza fasciata, 581 . georgiana, 584

lincolni, 583 .

Merganser americanus, 129. serrator, 130.

Merganser, A., 129.

Hooded, 131.

Red-breasted, 130 .

Merula migratoria, 761.

Micropalama himantopus, 233.

Milvulus forficatus, 443 .

Mimus polyglottos, 703 .

Mniotilta varia, 636 .

Mockingbird, 703 .

English, 703 .

French, 705.

Sandy, 705 .

Molothrus ater, 495.

Mother Carey's Chicken, 106, 109.

Mud-hen, Fresh-water, 208.

Salt-water, 211.

Myiarchus crinitus, 452.

NigHTHA WK, 420 .

Night Partridge, 228.

Numenius borealis, 266.

hudsonicus, 265.

longirostris, 264.

Nuthatch, Brown-headed, 729.

Red-breasted, 728 .

White-breasted, 727 .

Nyctala acadica, 372.

Nyctea nyctea, 376.

Nycticorax nycticorax navius, 202. violaceus, 203. 
OCEANITES OCEANICUS, 109.

Oceanodroma leucorhoa, 106.

Oidemia americana, 163. deglandi, 165 perspicillata, 166.

Old-squarv, 154

Olor buccinator, 181. columbianus. 180 .

Oriole, Baltimore, 507 . Orchard, 506

Ortolan, 214 King, 212, 219

Osprey, A..364.

Otocoris alpestris, 474 a. praticola, $474 b$

Oven-bird, 674.

Owl, Acadian, 372. Barn, A., 365.

Barred, 368

Booby, 368, 375.

Cat, 375 .

Great Horned, 375.

Hoot, 368, 375.

Little Gray, 373.

Little Red, 373.

Long-eared, A., 366.

Marsh, 367.

Monkey, 365.

Mottled, 373.

Saw-whet, 372 .

Screech, 373.

Short-eared, 367

Snowy, 376.

Ox-eye, 242,246

Oyster-catcher, A., 286.

PANDion haliä̈TUS CAROLINENSIS, 364.

Paroquet, Carolina, 382.

Partridge, 289.

Night, 228.

Parus atricapillus, 735.

bicolor, 731 .

carolinensis, 736 .

Passer domesticus, (after 517).

Passerella iliaca, 585.

Passerina cyanea, 598 .

Pavoncella pugnax, [260].

Peep, 242, 246.

Peet-weet, 263.

Pelecanus erythrorhynchos, 125. fuscus, 126.

Pelican, Brown, 126.

White, A., 125.

Petrel, Leach's, 106.

Wilson's, 109 .

Petrochelidon Junifrons, 612

Pewee, 456.

Bridge, 456

House, 456 .

Wood, 461.

Phalacrocorax carbo, 119

dilophus, 120.

Phalarope, Northern, 223. Red, 222.

Phalaropus lobatus, 223.

Phasianus colchicus, (after 305).

Pheasant, 300.

European, (after 305).

Philohela minor, 228.

Phobe, 456.

Pied Fisherman, 129.

Pigeon, Passenger, 315. Wild, 315 .

Pinicola enucleator, 515 .

Pintail, 143, 167.

Pipilo erythrophthalmus, 587.

Pipit, A., 697.

Piranga erythromelas, 608. rubra, 610 .

Plectrophenax nivalis, 534.
Plegadis autumnalis, 186.

Plover, Beetle-head, 270 .

Big Yellow-legs, 25t.

Black-bellied, 270 .

Black-breast, $243 a, 270$.

Bull-head, 270.

Field, 261.

Golden, A., 272.

Grass, 261.

Killdeer, 273.

Little Yellow-legs, 255.

Piping, 277.

Belted, 277a.

Ring, 274, 280 .

Ring-neck, 274, 280.

Semipalmated, 27.4 .

Upland, 261.

Wilson's, 280.

Yellow-legs, 254, 255.

Podilymbus podiceps, 6 .

Poke, 201.

Polioptila cærulea, 751.

Poocretes gramineus, 540.

Porzana carolina, 214.

jamaicensis, 216.

noveboracensis, 215.

Prairie Hen, 305.

Privateer, 332.

Progne subis, 611.

Protonotaria citrea, 637.

Puffinus auduboni, 92.

major, 89.

stricklandi, 94.

Purple Martin, 611.

QUA-BIRD, 202, 203.

Quail, 289.

European, (after 289).

Quiscalus major, 513 .

quiseula, 511 .

q. æeneus, $511 b$.

RAIL, BLACK, 216.

Carolina, 214.

Clapper, 211.

King, 208.

Sora, 214.

Virginia, 212

Yellow, 215.

Raincrow, 387, 388.

Rallus elegans, 208.

longirostris crepitans, 211.

virginianus, 212.

Raven, Northern, $486 \alpha$.

Redbird, 593, 610 .

Summer, 610 .

Redhead, 146.

Redpoll, 528 .

Redstart, A., 687.

Reedbird, 494.

Regulus calendula, 749 . satrapa, 748 .

Ring-billed Black-head, 150.

Ring-neek, 274, 280.

Rissa tridactyla, 40 .

River Shuftler, 149.

Robin, A., 761 .

Ground, 587

Marsh, 587.

Wood, 755 .

Rook, 167.

Ruff, [260].

Ruffed Grouse, 300.

Rynchops nigra, 80 .

SANDERLING, 248

Sandpiper, Baird's, 241.

Bartramian, 261.

Least, 242.

Pectoral, 239. 
Sandpiper, Red-backed, $243 a$.

Semipalmated, 216.

Solitary, 256.

Spotted, 263.

Stilt, 233.

Western, 247.

White Rumped, 240.

Sandy Mockingbird, 705.

Sapsucker, 393, 394, 402, 636, 727, 728.

Yellow-bellied, 402 .

Sayornis phobe, 456.

Scolecophagus carolinus, 509.

Scolopax rusticola [227].

Scoter, A., 163.

Surf, 166.

White-winged, 165.

Sea Dove, 34 .

Sea Srvallow, 74.

Sedge-hen, 211.

Seiurus aurocapillus, 674 .

motacilla, 676 .

noveboracensis 675 .

n. notabilis, $675 a$.

Setophaga ruticilla, 687

Shearwater, Audubon's, 92. Greater, 89.

Sooty, 94 .

Sheldrake, 129, 130

Shitepoke, 201.

Shovel-bill, 142.

Shoveller, 142.

Shrike, Loggerhead, 622. Northern, 621.

Shuffler, 148.

River, 149.

Sailia sailis, 766 .

Siskin, Pine, 533.

Sitta canadensis, 728.

carolinensis, 727.

pusilla, 729.

Skimmer, Black, 80 .

Sky-lark, 474.

Sleepy Brother, 167.

Snakebird, 118.

Snipe, Black-breasted, $243 a$. English, 230.

Grass, 239.

Gray, 234.

Gray-back, 231.

Jack, 230, 239 .

Marsh, 230.

Robin, 234.

Robin-breasted, 234.

Sand, 212, 246, 256, 263.

Wilson's, 230.

Snowbird, 567.

Snow Bunting, 534.

Snow-flake, 534.

Snowl, 131.

Somateria dresseri, 160 .

spectabilis, 161.

Sora, 214

Southerland, 154.

Southerly, 154

South Southerly, 15..

Sparrow, Bay-winged, 510.

Blue, 598.

Bull, 581.

Chipping, 560 .

Winter, 559 .

Englisb, (after 517).

Field, 563 .

Fox, 585 .

Grasshopper, 546

Ground, 581.

Henslow's, 517.

Ipswich, 541 .

Lark, 552.

Lincoln's, 583.

Savanna, $512 c$
Sparrow, Seaside, 550.

Sharp-tailed, 519.

Acadian, $549 b$.

Nelson's, $549 a$.

Song, 581 .

Swamp, 584.

Tree, 559.

Vesper, 540.

White-crowned, 554 .

White-throated, 558 .

Yellow-winged, 516.

Spatula clypeata, 142.

Sphyrapicus varius, 402 .

Spinus pinus, 533.

tristis, 529.

Spiza americana, 604 .

Spizella monticola, 559.

pusilla, 563.

socialis, 560 .

Spoon-bill, 142.

Sprigtail, 143.

Squawk, 202, 203.

Steel-head, 167.

Stelgidopteryx serripennis, 617.

Stercorarius longicaudus, 38.

parasiticus, 37 .

pomarinus, 36 .

Sterna antillarum, 74 .

dougalli, 72 .

forsteri, 69 .

fuliginosa, 75

hirundo, 70 .

maxima, 65.

paradisæa, 71 .

tschegrava, 64 .

Stiff-tail, 167.

Stilt, Black-necked, 226.

Storm-bird, 731 .

Striker, 69, 70 .

Little, 74 .

Strix pratincola, 365 .

Sturnella magna, 501 .

Sula bassana, 117.

Swallow, Bank, 616.

Barn, 613.

Chimner, 423.

Cliff, 612.

Eave, 612 .

Rough-winged, 617.

Sea, 74.

Tree, 614

White-bellied, 614 .

Swan, Trumpeter, 181.

Whistling, 180 .

Swift, Chimney, 423.

Sylvania canadénsis, 686 .

mitrata, 684.

pusilla, 685 .

Symphemia semipalmata, 253.

Syrnium nebulosum, 368 .

TACHYCINETA BICOLOR, 614.

Tanager, Scarlet, 608 .

Summer, 610 .

Tantalus loculator, 188.

Tar-bucket, $163,165,166$.

Tar-pot, 163, 165, 166.

T'eal, 139, 140.

Blue-winged, 140

European [138].

Green-winged, 139

Tern, Arctic, 71 .

Black, A., 77.

Caspian, 64.

Common, 70.

Forster's, 69.

Gull-billed, 63 .

Lenst, 74 .

Marsh, 63.

Roseate, 72 
Tern, Royal, 65.

Sooty, 75 .

Wilson's 70 .

Thistle-bird, 529

Thrasher, Brown, 705.

Thrush, Bicknell's, 757

Brown, 705 .

Gray-cheeked, 757.

Hermit, $759 b$.

Olive-backed, $758 \alpha$.

Tawny, 756.

Wilson's, 756

Wood, 755 .

Water, 675 .

Grinmell's, 675ct

Louisiana, 676.

Thryothorus bewickii, 719 .

ludovician us, 718 .

Tilt, 263.

Tilt-ass, 263.

Tilter, 263.

Tilt-up, 263.

Tip-up, 263.

Titlark, 697

Titmouse, 'T'ufted, 731 .

Totañus flavipes, 255

melanoleucus, 254.

solitarius, 256.

Towhee, 587 .

Tringa aipina pacifica, $243 \alpha$.

bairdii, 241.

canutus, 234.

fuscicollis, 240 .

maculata, 239.

minutilla, 242 .

Trochilus colubris, 428.

Troglodytes aëdon, 721 .

hiemalis, 722 .

Turdus alicia, 757.

a. bicknelli, 757 \%

aonalaschkre pallasii, $759 b$.

fuscescens, 756 .

mustelinus, 755 .

ustulatus swainsonii, $752 \alpha$.

Turkey Buzzard, 325 . Vulture, 325.

Turkey, Water, 118. Wild, 310 .

Turnstone, 283.

Tympanuchus americanus, 305.

Tyrannus tyrannus, 444 .

verticalis, 447 .

URINATOR MMBER, 7 .

lumme, 11.

VIREO FLAVIFRONS, 628. gilvus, 627 .

noveboracensis, 631 . olivaceus, 624 .

philadelphicus, 626 .

solitarius, 629 .

Vireo, Blue-headed, 629.

Philadelphia, 626 .

Red-eyed, $62 t$.

Warbling, 627

White-eyed, 631

Yellow-throated, 628 .

Vulture, Black, 626 .

Turkey, 625 .

IVALLOON, 7.

Warbler, Bay-breasted, 660.

Black and White, 636 .

Black and Yellow, 657 .

Blackburnian, 662 .

Black-poll, 661 .

Black-throated Blue, 654.

Black-throated Green, 667.

Blue-winged, 641 .

Warbler, Blue Yellow-backed, 648.

Brewster's, (after 641).

Canadian, 686 .

Cape May, 650.

Cerulean, 658.

Chestnut-sided, 659.

Connecticut, 678.

Golden-winged, 642 .

Hooded, 684.

Kentucky, 677.

Kirtland's, 670 .

Magnolia, 657.

Maryland Yellow-throat, 681.

Mourning, 679 .

Myrtle, 655 .

Nashville, 645 .

Orange-crowned, $6 \pm 6$.

Palm, 672.

Parula, 618 .

Pine, 671.

Prairie, 673.

Prothonotary, 637.

Red-poll, 672 .

Tennessee, 647.

Wilson's 685 .

Worm-eating, 639.

Yellow, 652.

Yellow Palm, 672a.

Yellow Red-poll, 672 $x$.

Yellow-rumped, 655.

Yellow-throated, 663.

Water Partridge, 139, 167.

Water 'h'mush, 675 .

Grinnell's, 675a.

Large-billed, 676 .

Louisiana, 676.

Small-billed, 675.

Water Turkey, 118.

Water-witch, 6.

Waxwing, Cedar, 619.

Wheeler, 412 .

Whitter, 151 .

Whip-poor-will, 417.

Whistler, 151.

Widgeon, 136.

European, 136.

Gray, 143.

Wild Canary, 529, 652 .

Willet, 258 .

Woodcock, 228, 405 .

A. 228 .

European [22\%

Wood-hen, 405.

Wood-lark, 674 .

Woodpecker, Downy, 394.

Hairy, 393.

Ivory-billed, 392.

Pileated, 405.

Red-bellied, 409.

Red-cockaded, 395.

Red-headed, 406.

Yellow-bellied, 402 .

Wood-robin, 755

Wren, Bewick's, 719 .

Carolina, 718 .

House, 721 .

Long-billed Marsh, 725.

Short-billed Marsh, 724 .

Winter, 722 .

XANTHOCEPHALUS XANTHOCEPHALUS, 497 .

YELLOW BIRD, 529, 652.

Yellow-breasted Chat, 683 .

Yellow-hammer, 412 .

Yellow-legs, 255, 254. Greater, 254

ZENAIDURA MACROURA, 316.

Zonotrichia albicollis, 558 . leucophrys, 554 . 


\section{WORKS AND PERIODICALS REFERRED TO.}

A. C.-Avifauna Columbiana, being a list of birds ascertained to inhabit the District of Columbia, etc., by Elliott Coues and D. W. Prentiss. Second edition, 1883. (This includes the first edition, 1861, and the gist of P. L. Jouy's list of 1877.)

A. (D. U. -The American Ornithologists' Union, Check List of North American Birds, 1886. (This is the present standard of nomenclature.)

Andubom.-The Birds of America, by John James Audubon, Vols. I to VII, 1840-44.

Auk. - The Auk, a quarterly Journal of Ornithology. (The official organ of the American Ornithologists' Union. Vol. I, No. 1, appeared January, 1884.)

B. N. D. C.-Bulletin of the Nuttall Ornithological Club. (Vol. I, No. 1, appeared in January, 1876. In 1881 it was continued as the Auk.)

Bendire.-Life Histories of North American Birds, with special reference to their breeding habits, and eggs, by Chas. Bendire, 1892. (Gallinaceous Birds, and Birds of Prey.)

Birols W. Pa. and Y. J.-The Birds of Eastern Pennsylvania and New Jersey, by Witmer Stone, 1894.

Birds N. W.-Birds of the North-West, by Elliott Coues, 1877.

Birds Pa.--Report of the Birds of Pennsylvania by B. H. Warren. Second edition, 1890
Biruls Vas.-A Catalogue of the Birds of the Virginias, by Wm. C. Rives, October, 1890.

Chapman.- Handbook of the Birds of Eastern North America, by Frank M. Chapman, 1895.

Fisher's Hawks and OwIs.-The Hawks and $O$ wls of the United States in their Relation to Agriculture, by A. K. Fisher, 1893 .

Norest and Stream.-A weekly Journal of the Rod and Gun. (Vol. XXVI, No. 1, January 27,1886 , is the first number I have access to. Two volumes each year. No. 1 bearing date of the fourth Thursday of January or July.)

Kiey.-Key to the North American Birds, by Elliott Coues. Fourth edition, 1890.

Manua I. - A Manual of North American Birds, by Robt. Ridgway, 1887.

1. amd 9.-The Ornithologist and Oölogist: Birds, their nests and eggs. (A monthly publication begun in 1876 . issued by several parties, published to Vol. XVIII, No. 10, October, 1893.

Dologist.-The Oölogist, for the student of birds, their nests and eggs. (A monthly publication begun in 1884.)

Smitl. Rept.-Annual Report of the Board of Regents of the Smithsonian Institution (year, not vol.). 










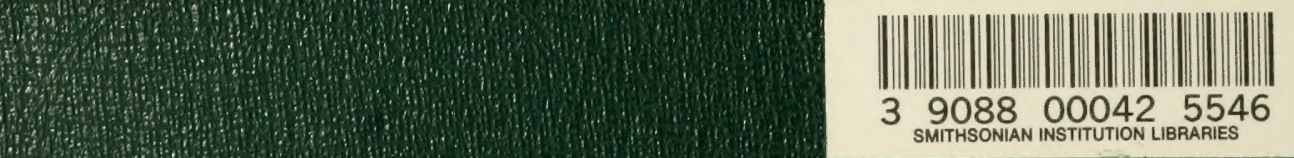

